Journal of Southeast Asian

\title{
Biểu Đạt Căn Tính Di Dân trên Quê Hương Việt-Mỹ và tại Hải Ngoại 1975-2015:Từ Những Tự Phát Sắc Tộc đến Thể Hiện Toàn Cầu
}

Trangdai Glassey-Tranguyen

Vietnamese Diasporas Projects, vietamproj@gmail.com

Follow this and additional works at: https://docs.lib.purdue.edu/jsaaea

Part of the South and Southeast Asian Languages and Societies Commons

\section{Recommended Citation}

Glassey-Tranguyen, Trangdai (2016) "Biểu Đạt Căn Tính Di Dân trên Quê Hương Việt-Mỹ và tại Hải Ngoại 1975-2015:Từ Những Tự Phát Sắc Tộc đến Thể Hiện Toàn Cầu," Journal of Southeast Asian American Education and Advancement: Vol. 11 : Iss. 1, Article 3.

DOI: $10.7771 / 2153-8999.1146$

Available at: https://docs.lib.purdue.edu/jsaaea/vol11/iss1/3

This document has been made available through Purdue e-Pubs, a service of the Purdue University Libraries. Please contact epubs@purdue.edu for additional information.

This is an Open Access journal. This means that it uses a funding model that does not charge readers or their institutions for access. Readers may freely read, download, copy, distribute, print, search, or link to the full texts of articles. This journal is covered under the CC BY-NC-ND license. 


\title{
ISAAEA Journal of Southeast Asian American Education and Advancement
}

Volume $11(2016)$

WWW.JSAAEA.org

\section{Biểu Đạt Căn Tính Di Dân trên Quê Hương Việt-Mỹ và tại Hải Ngoại 1975-2015: Từ Những Tự Phát Sắc Tộc đến Thể Hiện Toàn Cầu}

\author{
Trangđài Glassey-Trầnguyễn
}

\section{EDITOR'S NOTE}

The following is a Vietnamese summary of "Articulating Refug-endity in VietnAmerica and the Diasporas 1975-2015: From Ethnic Autonomy to Global Visibility," by Trangdai GlasseyTranguyen, which was published in Vol 10 of JSAAEA (http://docs.lib.purdue.edu/jsaaea/vol10/iss 1/5/). This summary was prepared by the author.

TÙ KHOÁ: refug-endity (căn tính di dân, di-dân-tính), quê hương Việt-Mỹ (VietnAmerica), hải ngoại, tự phát sắc tộc, thể hiện toàn cầu, lịch sử truyền khẩu, nghiên cứu thực tế/cộng đồng (ethnographic fieldwork), tương quan thế hệ, tiếng Việt, tính chính trị trong ký ức và hồi tưởng, Chiến tranh Việt Nam, Hiệp định Geneva, tự do, kinh nghiệm thuyền nhân, hỏa lò Việt Nam trại cải tạo, chế độ đô hộ Pháp, di tản/tái định cư, khái niệm 'nhà/quê nhà,' bản thể lịch sử/bản thể cá nhân/bản thể chính trị, ký ức, rối loạn tâm lý hậu chấn thương (PTSD), thế hệ bắc cầu 1.5

\section{GHI CHÚ VỀ BẢN TIẾNG VIẸT:}

Việc chuyển ngữ tự bản chất là một phóng tác - ngay cả khi tác giả chuyển ngữ chính tác phẩm của mình, vì mỗi ngôn ngữ mang một phong thái riêng và chứa đựng văn hoá, lịch sử của nó. Trong bản tiếng Việt này, tôi cố viết sao vừa sát nghĩa, vừa thoát ý từ bản tiếng Anh; đồng thời giữ cho hai bản gần nhau đến mức tối đa có thể. Có những chữ không thể dịch trọn vẹn từ tiếng Anh sang tiếng Việt được, vì bối cảnh và lịch sử tư duy của nó trong ngôn ngữ nó được tạo ra mà qua đó nó đã hình thành một ý nghĩa nhất định, như chữ 'autonomy' trong học thuật Anh ngữ. Do đó, tôi chọn giữ lại chữ tiếng Anh trong ngoặc đơn khi cần thiết.

Thêm vào đó, có những chữ do tôi tạo ra trong tiếng Anh, như 'refug-endity' và VietnAmerica, nhưng không thể lập lại quá trình sáng tạo đó một cách hoàn toàn trong tiếng Việt vì những khác biệt về cấu trúc trong hai ngôn ngữ. Vì chữ 'refug-endity' là chủ đề chính của bài, tôi sẽ đưa chữ phỏng dịch trong tiếng Việt ở đầu bài, và dùng chữ tiếng Anh 'refug-endity' trong suốt bài viết. Tương tự, tôi tạo ra chữ 'VietnAmerica' từ thập niên 1990s bằng cách kết hợp hai chữ Vietnam và America để nói đến tính bắc cầu của cộng đồng Việt tại Mỹ, một không gian của người Việt di dân ngay giữa lòng xã hội Hoa Kỳ. Trong tiếng Việt, tôi tạm dịch là 'quê hương Việt-Mỹ,' nhưng cụm từ này không thể hiện được sự nối kết nên một mà chữ 'VietnAmerica' chuyển tải.

(c)

SDRERIGHISRESERVEDReaders are free to copy, display, and distribute this article, as long as the work is attributed to the author(s) and the Journal of Southeast Asian American Education \& Advancement, it is distributed for non-commercial purposes only, and no alteration or transformation is made in the work. More details of this Creative Commons license are available at http://creativecommons.org/licenses/by-nc-nd/3.0/. All other uses must be approved by the author(s) or JSAAEA.

Journal of Southeast Asian American Education \& Advancement, Vol. 11 (2016) ISSN: 2153-8999 
Trangdai Glassey-Tranguyen- Biểu Đạt Căn Tính Di Dân trên Quê Huơng Việt-Mỹ và tại Hải Ngoại

Tôi cũng chọn giữ lại nguyên văn các trích đoạn tiếng Anh, ngay sau phần dịch tiếng Việt, để đọc giả nào am tường cả hai ngôn ngữ có thể đối chiếu. Có những từ không thể dịch ra tiếng Việt, như các thuật ngữ của nhạc rap chẳng hạn, và tôi chọn giữ nguyên các từ này với chú thích của tôi trong ngoặc đơn. Kính mời quý độc giả theo dõi cả hai bản Anh và Việt để thấy được những khác biệt này, cũng như sự độc đáo của mỗi ngôn ngữ.

\section{TÓM LƯợC}

Từ khi cuộc chiến Việt Nam kết thúc ngày 30 tháng Tư, 1975, nhiều đợt người Việt di tản, tỵ nạn, và di dân đã đến Hoa Kỳ và xây dựng một mái ấm mới trên toàn quốc. Quận Cam, California, là nơi tập trung người Mỹ gốc Việt nhiều nhất từ năm 1975, và được mệnh danh là "thủ đô tỵ nạn của người Việt" tại hải ngoại. Tôi cho rằng có một nền văn học và truyền thông tiếng Việt tự phát, sung mãn tuy chưa được nghiên cứu thoả đáng - tại Quận Cam và quê hương Việt-Mỹ (VietnAmerica) từ năm 1975. Nền văn học và truyền thông này tạo ra mảnh đất màu mỡ cho việc biểu đạt cái mà tôi gọi là 'refug-endity' - một căn tính di dân. Những tài liệu xuất bản và tác phẩm văn hoá bằng Việt ngữ này mang tính tự phát và tự lực (autonomous), nhưng ẩn mình đối với dòng chính Hoa Kỳ vì những rào cản văn hoá và ngôn ngữ. Tuy vậy, tôi cho rằng căn tính di dân 'refug-endity' dù có vẻ như bị cô lập - lại có một đời sống tiềm tàng nhưng toả lan, và được tiếp nối qua những sáng tạo của các nghệ sĩ gốc Việt lớn lên ở hải ngoại. Bốn mươi năm sau, refug-endity đã tiến triển từ những tự phát và tự lực trong cộng đồng sắc tộc thành những biểu hiện toàn cầu, với những vụ mùa mới đang triển nở ở hải ngoại và sự bừng nở của phong trào phục hoạt ngôn ngữ sắc tộc trong dòng chính gần đây cũng như từ bốn mươi năm qua trong cộng đồng nhà. Bài viết này dựa trên các công trình nghiên cứu của tôi, cũng như kinh nghiệm sống mười chín năm ở Việt Nam và hơn hai thập niên tại Quận Cam và tại những cộng đồng Việt hải ngoại khác trên thế giới. Đặc biệt, bài viết này dựa trên kinh nghiệm đa chiều của tôi: từ những hiểu biết trực tiếp trong đời sống hằng ngày, những chương trình học thuật chuyên ngành tôi đã theo đuổi, và những đóng góp của tôi vào sự thành lập và phát triển các văn khố tiếng Việt, những sinh hoạt về truyền thông và văn hoá mà tôi xúc tiến hoặc tham gia, và những tài liệu gốc từ cộng đồng sắc tộc tại Quận Cam (và những nơi khác) mà tôi thu thập trong bốn mươi năm qua. Qua việc phân tích các tác phẩm và chương trình liên quan đến refug-endity, tôi quán chiếu về bốn thập niên của những sáng tạo bằng tiếng Việt, những đề tài, và giá trị kinh tế chính trị vốn cho phép những sinh hoạt này tìm được mạch sống.

\section{Mở ĐẦU}

Sau bốn mươi năm cộng đồng Việt Nam hải ngoại định hình, nhiều thế hệ nghệ sĩ gốc Việt đáp lại tiếng gọi sáng tạo và tận hiến cho việc ghi lại kinh nghiệm của mình qua nghệ thuật, và qua đó, giúp tiếp tục những biểu hiện, tìm kiếm, và xiển dương kinh nghiệm của người Việt hải ngoại

- một di sản được trao truyền lại cho các thế hệ tương lai để giúp họ gắn bó với nguồn gốc. 
Trangdai Glassey-Tranguyen- Biểu Đạt Căn Tính Di Dân trên Quê Huoong Việt-Mỹ và tại Hải Ngoại

\section{Ý NGHĨA}

Bài viết này nhằm vào việc đưa ra một cái nhìn tổng quát và phân tích 'refug-endity' trên quê hương Việt-Mỹ VietnAmerica và tại hải ngoại từ năm 1975 đến năm 2015. Bài viết mở đầu với việc lập luận và tìm hiểu về tính tự phát và tự lập của các thế hệ tỵ nạn, và kết thúc với những biểu hiện nghệ thuật toàn cầu của các thế hệ sinh trưởng tại hải ngoại. Vì chủ đề nằm sâu trong kinh nghiệm tỵ nạn và di dân khởi đi từ chiến tranh Việt Nam, tôi cho rằng có một sự nối tiếp xuyên thế hệ trong căn tính di dân refug-endity của người Việt hải ngoại cho dù có những giằng co ngôn ngữ và khác biệt giữa các thế hệ. Bài viết góp phần vào việc tìm hiểu văn chương nghệ thuật Việt tại hải ngoại, với trọng tâm là những biểu đạt về căn cước di dân và tương quan thế hệ. Những dữ liệu gốc bằng tiếng Anh và Việt được xuất bản lần đầu trong bài này, những trích đoạn lịch sử truyền khẩu tôi chọn từ văn khố của hai thập niên nghiên cứu về người Việt tại nhiều nơi trên thế giới, cũng như phần dịch tiếng Anh của những tài liệu tiếng Việt liên quan đến chủ đề - sẽ là những đóng góp vô song cho đề tài refug-endity và những đề tài tương tự. Quan trọng hơn cả, bài viết này là nhịp cầu nối giữa văn chương tiếng Anh và văn chương tiếng Việt trong cộng đồng người Việt hải ngoại, và giữa giới học thuật và độc giả ngoài học thuật (cũng như độc giả thuộc cộng đồng sắc tộc) vì bài viết hướng đến độc giả mọi giới (accessibility), đi từ kinh nghiệm thực tế (groundedness), và mang tính cộng thông (inclusive).

\section{TỔNG QUÁT}

Mở đầu bài viết này', tôi nhìn về nền văn học do người Mỹ gốc Việt sáng tác và xuất bản trong tiếng Việt từ năm 1975 tại hải ngoại. Tôi cho rằng nền văn học này ẩn mình và không được tiếp cận bởi dòng chính tại Hoa Kỳ và giới học thuật, và do đó không được biết đến và không được dẫn chứng trong các tài liệu học thuật Anh ngữ. Nhưng nền văn học sung mãn này đã có nhiều đóng góp quan trọng cho việc biểu đạt, ghi lại, và tìm hiểu kinh nghiệm của người Mỹ gốc Việt, nhất là về cuộc chiến Việt Nam từ góc nhìn của người Việt, những hậu quả sau chiến tranh, và sự hình thành của quê hương Việt-Mỹ VietnAmerica. (VietnAmerica là một từii tôi đặt ra và dùng từ giữa thập niên 1990s để nói đến thực thể kinh tế, chính trị, xã hội, văn hoá, giáo dục, nghệ thuật, tư tưởng, và địa lý của người Việt tại Mỹ; và nhấn mạnh vào sự liên đới của thực thể này với hợp chủng quốc, tính bắc cầu của nó, và căn tính liên quốc gia của nó.) Do đó, cõi sáng tạo tự phát và tự lập này - với những căng thẳng và giằng co nhất định ${ }^{\text {iii }}$ - tạo nên cái mà tôi gọi là di-dân-tính refug-endity, vốn phản ánh kinh nghiệm và cái nhìn của người gốc Việt tại Hoa Kỳ, và độc lập cũng như khác với cái quan niệm 'người di dân' bán diện hay đóng khuôn (systemic) trong dòng chính Hoa Kỳ hay trong học thuật.

Bài viết này chú trọng vào những tài liệu xuất bản và tác phẩm văn hoá tiếng Việt tại quê hương VietnAmerica và tại hải ngoại, vốn rất cần được tìm hiểu nhưng chưa được nghiên cứu thoả đáng. Bài viết này đi từ kinh nghiệm thực tế của tôi qua quá trình tham gia vào và tìm hiểu về những sinh hoạt này từ đầu thập niên 1990s. Những nhận định và lập luận của tôi đều dựa trên những kinh nghiệm và đóng góp trực tiếp. Về mặt này, và vì những giới hạn của một bài viết, tôi sẽ không bàn đến những tài liệu học thuật khác, và sẽ làm việc này trong tương lai. Để đáp lại sự vắng mặt của những tác phẩm liên ngôn ngữ nhằm nối mạch cho nền văn học tiếng Việt với độc giả tiếng Anh, bài viết này quán chiếu quá trình xuất bản bằng tiếng Việt trong bốn mươi năm qua, những chủ đề chính, và giá trị kinh tế chính trị đã giúp cho những tác phẩm này khơi màu.

Từ cuối thập niên 1970s đến giữa thập niên 1990s, việc phát hành những ấn phẩm của 
Trangdai Glassey-Tranguyen- Biểu Đạt Căn Tính Di Dân trên Quê Huoong Việt-Mỹ và tại Hải Ngoại

các sáng tác từ các văn nghệ sĩ người Việt tỵ nạn đã bừng nở, nhất là tại Quận Cam, California. Những ấn phẩm này vừa cũ vừa mới - được viết và xuất bản trước và sau 1975 - bởi những người Việt tỵ nạn đã định cư tại Hoa Kỳ và các nơi khác, cũng như bởi những ai vẫn còn đang cố gắng thoát khỏi Việt Nam. Bài viết này không nhằm vào việc hệ thống hoá nền văn học này, nhưng tìm hiểu về vai trò của nó trong tâm thức và kinh nghiệm của người Mỹ gốc Việt bằng cách nhìn lại một số tác phẩm thích hợp ${ }^{\mathrm{iv}}$ và đối thoại với nhiều đề tài và tác giả có liên quan đến chủ đề được đặt ra. Với sự bùng nổ của truyền thông trên mạng vào đầu thập niên 2000s ngay sau bong bóng .com bị nổ năm 1997, những trang và tạp chí văn chương trên mạng phát triển mạnh, và giúp tăng thêm sự nối kết giữa tác giả và độc giả tiếng Việt khắp nơi trên thế giới. Thế giới văn chương Việt tại Hoa Kỳ - vốn đã đóng vai trò tiên phong trong cộng đồng Việt hải ngoại - lại trở nên toàn cầu hơn với mạng điện toán. Ngày nay, cõi văn chương của người Việt tại hải ngoại càng đa dạng và đa ngữ, với tiếng Việt - tuy không còn đóng vai trò độc tôn nhưng vẫn là điểm tham khảo văn hoá và một nguồn cảm hứng.

Để kết, tôi hướng đến những nghệ sĩ và tác giả gốc Việt thế hệ ngoại biên ('ngoại biên' là chữ tôi dùng để chỉ những người Việt sinh trưởng tại hải ngoại), vốn không sử dụng tiếng Việt là chính, và cách họ vật lộn với tiếng mẹ đẻ: một là dùng nó trong sáng tạo, hoặc là kính ngưỡng nó như một cái gì rất thiêng liêng và không dám dùng đến. Với chiều hướng nào đi nữa, những thế hệ trẻ cho thấy một sự nối tiếp rất uẩn áo và/hoặc trực tiếp của kinh nghiệm di dân. Dù có chủ đích hay không, tác phẩm của họ là một cách tỏ lòng tri mộ đối với những người cầm bút thuộc thế hệ tỵ nạn, những người đã dùng tác phẩm của mình để tạo nên những định nghĩa đầu tiên cho refug-endity trên quê hương Việt-Mỹ và trên thế giới. Sự tiếp nối này diễn đạt cách hùng hồn mối tương quan liên thế hệ của văn chương di dân, không như học thuật truyền thống vẫn cho rằng bị đứt khúc và phân chia giữa thế hệ di dân và thế hệ ngoại biên. Ở đây, tôi cho rằng những nghệ sĩ gốc Việt tại hải ngoại 'đi hai hàng' - một cách đi phức tạp - giữa những lằn ranh thế hệ, khi họ đặt câu hỏi về quá khứ và di sản của mình để mặc lấy một vai trò chủ động trong việc đưa ra những cơ hội mới và để làm mới cách định nghĩa refug-endity. Với ý thức về tính cách liên thế hệ này, đây là lần đầu tiên có một bài viết quy tụ những tác phẩm sáng tạo của người Việt hải ngoại từ nhiều thế hệ và từ những ngôn ngữ và/hoặc thể loại khác nhau, và đối chiếu những tiếng nói đã từng hiện hữu độc lập với nhau để cho thấy sự liên quan của chúng. Sau bốn mươi năm cộng đồng Việt Nam hải ngoại định hình, nhiều thế hệ nghệ sĩ gốc Việt đáp lại tiếng gọi sáng tạo và tận hiến cho việc ghi lại kinh nghiệm của mình qua nghệ thuật, và qua đó, giúp tiếp tục những biểu hiện, tìm kiếm, và xiển dương kinh nghiệm của người Việt hải ngoại - một di sản được trao truyền lại cho các thế hệ tương lai để giúp họ gắn bó với nguồn gốc.

Đối với những hoạ sĩ ngoại biên lớn lên sau khi cuộc chiến Việt Nam kết thúc, tôi trích dẫn nhiều vị sáng tác trong cũng như bên cánh đồng chữ nghĩa - những nghệ sĩ truyền thống là những người cầm bút như thi sĩ, và những nghệ sĩ tạo hình và nghệ sĩ trình diễn. Tôi cho rằng cách nhìn này thật thích hợp trong xã hội multi-media xuyên-thể-loại hôm nay, nơi mà những biên giới liên-thể-loại luôn luôn bị thách thức, trở nên hữu dụng (productive), và thăng hoa. Những nghệ sĩ này là đợt sóng mới của giới văn nghệ sĩ gốc Việt tại hải ngoại. Di sản Việt Nam được trình bày một cách nổi bật trong sáng tác của họ - một di sản vừa tác động lên nghệ thuật của họ, vừa chịu ảnh hưởng từ những cái nhìn nghệ thuật mới của họ. Sáng tác của họ đưa ra một hình thức 'văn học' khác, dâng hiến những cuộc gặp gỡ qua tạo hình và ẩn dụ của những nguyên bản và bối cảnh nói về lịch sử Việt Nam và những mảng vỡ của nó. Do đó, những nền nghệ thuật tạo hình và trình diễn này nói trực tiếp về và khởi đi từ những tài liệu trong văn khố, tận dụng cả những cổ vật và chữ nghĩa từ quá khứ của Việt Nam và những di chứng (tôi đặt ra từ này để dịch thoát chữ 'implication') tại hải ngoại. Trong ý nghĩa đó, 'văn học di dân' như một thể loại sẽ 
Trangdai Glassey-Tranguyen- Biểu Đạt Căn Tính Di Dân trên Quê Huoong Việt-Mỹ và tại Hải Ngoại

không bị gò bó trong những tác phẩm liên quan đến văn chương mà thôi, mà tất cả những tác phẩm nói về kinh nghiệm và hoàn cảnh của Việt Nam, cộng đồng Việt hải ngoại, và tương quan với thế giới. Quan trọng hơn nữa, những tác phẩm này gợi ra những cách nhìn mới về hình ảnh 'người tỵ nạn' và tương tác với quá trình thể hiện văn hoá tỵ nạn trên toàn cầu, thắp sáng không gian và cái nhìn sắc-tộc-Việt về cuộc chiến Việt Nam và các biến cố lịch sử khác vốn từ trước đến nay bị câm nín hay đẩy vào thứ yếu trong lịch sử Tây phương.

Những tài liệu trong bài viết này được rút ra từ những dự án tôi đã thực hiện trong nhiều cộng đồng Việt hải ngoại trên khắp thế giới và kéo dài nhiều thập niên từ năm 1994, trong đó có Dự án Việt Mỹ (Vietnamese American Project) đoạt nhiều giải thưởng, Dự án Việt Stockholm (Vietnamese Stockholm Project) do chương trình Fulbright bảo trợ, và Dự án Việt Berlin (Vietnamese Berlin Project), cùng các dự án khác. Những dự án đa-thể-loại này kết hợp phương pháp lịch sử truyền khẩu đa ngữ, nghiên cứu thực tế/cộng đồng kéo dài hàng thập niên, và phân tích liên ngành. Trong bài tiếng Anh, tôi đưa ra những tài liệu gốc chưa bao giờ được xuất bản từ những cuộc phỏng vấn và bình luận tôi đã xuất bản bằng tiếng Việt, cũng như bản dịch tiếng Anh của một số tài liệu nguyên tác bằng Việt ngữ. Tôi viết những bài điểm sách hay bình luận nghệ thuật cho những tác phẩm sắp xuất bản hay những cuộc triển lãm qua lời mời của Chủ bút hay chính tác giả, hoặc người đảm trách nội dung cuộc triển lãm (curator). Những bài bình luận này được đăng song song ở nhiều nơi, cả in lẫn ảo, tại hải ngoại, như Gió $\mathrm{O}$, Diễn Đàn Thế Kỷ, Thư Viện Sáng Tạo, Da Màu, Trí Nhân Media, Tương Tri, Sống Weekly, Trẻ Weekly (Texas), Người Việt Daily, Việt Báo Daily, Viễn Đông Daily, Nguyệt san Hiệp Nhất, Diễn Đàn Giáo Dân, Thư Viện Hoa Sen, Trang Phụ Nữ Việt, Nguyệt san Việt Nam (tờ báo duy nhất của người Việt tại Hoà Lan), và nhiều nơi khác.

Xin nói thêm rằng trong suốt bài viết này cũng như trong nghiên cứu của tôi trong hai thập niên qua, tôi luôn ưu tiên tiếng nói và cái nhìn của các tác giả và nghệ sĩ gốc Việt, và coi những tiếng nói và cái nhìn này như dữ liệu cũng như lý thuyết. Nói cách khác, với những tiếng nói và cái nhìn này làm trung tâm của mọi thảo luận, sáng tạo nghệ thuật về người Việt tỵ nạn (Vietnamese refugee aesthetics) tỏ lộ bản năng tự phát tự lập, tính tự lực, và tự quyết ngay từ trong trứng nước.

\section{ĐỊNH NGHĨA DI-DÂN-TÍNH REFUG-ENDITY}

Phần này cung cấp những nét lịch sử đại cương về refug-endity để làm một nền tảng cho bài viết. Những trích đoạn gốc ở đây được chọn từ những tác phẩm do tôi dịch (từ tiếng Việt sang tiếng Anh trong bản Anh ngữ); có một số trích đoạn chứng từ lịch sử truyền khẩu nhằm đề cao cái nhìn của người kể và để tôn trọng nhiều hình thức biểu đạt khác nhau. Tuy cao trào người Việt tỵ nạn diễn ra vào khoảng năm 1975, người Việt đã có mặt tại Châu Mỹ trước đó. Từ thập niên 1950s, quan hệ bang giao quốc tế và những trao đổi về giáo dục đã đưa nhiều nhóm người Việt đến Mỹ, và có nhiều người đã ở lại khi Sài Gòn thất thủ. Những gặp gỡ văn hoá, tuy nhiên, đã có rất lâu trước đó. Đối với người Việt, khái niệm refug-endity không chỉ nảy sinh với biến cố Sài Gòn thất thủ năm 1975 khi họ rời quê hương ở một con số vô tiền khoáng hậu, nhưng còn trước đó rất lâu và trong khi họ vẫn còn ở tại Việt Nam (Glassey-Tranguyen, 2014a). Tuy kinh nghiệm di dân của người Việt (hay các dân tộc khác) đã diễn ra hàng trăm năm, nhưng trong khuôn khổ bài viết này, tôi chỉ nhắc đến giai đoạn từ thế kỷ 20 đến hôm nay vì nó liên quan trực tiếp đến chủ đề của bài. Người Việt đã là người tỵ nạn ngay trên quê hương mình với cuộc di cư từ Bắc vào Nam năm 1954, cuộc thảm sát và chạy loạn Tết Mậu Thân 1968, bên cạnh những biến cố 
Trangdai Glassey-Tranguyen- Biểu Đạt Căn Tính Di Dân trên Quê Huơng Việt-Mỹ và tại Hải Ngoại

khác trong thời Pháp thuộc và chiến tranh Việt Nam. Vì sự gắn bó với quê quán trong văn hoá Việt Nam, những ai sống xa quê thường tự gọi mình là sống đời "một cảnh hai quê." Hoàn cảnh ly hương này cũng giống như những gia đình bị chẻ ra trong thế giới toàn cầu, với người lưu dân (chữ tôi đặt ra để nói đến những người sống lưu lạc xa quê để mưu sinh) đi làm xa nhà và gửi tiền về cho gia đình ở cố quốc.

Trong các chứng từ lịch sử cá nhân tôi ghi nhận từ thập niên 1990s của người Mỹ gốc Việt và người Việt hải ngoại trên thế giới, đề tài di cư và tái định cư luôn được đề cập đến. Như tôi đã lập luận trong các bài viết khác, những biến cố lớn - như Hiệp định Geneve 1954 và cuộc di cư vào Nam của hàng triệu đồng bào từ miền Bắc sau đó - che khuất những khuynh hướng di dân đa chiều và phức tạp hơn tại Việt Nam trong thế kỷ hai mươi (Tranguyen, 2004a; GlasseyTranguyen, 2015). Chẳng hạn, trong thập niên 1940s-1950s, Việt Nam đang ở đỉnh cao của hỗn loạn, vừa đối phó với sự sụp đổ của chế độ thuộc địa Pháp, với quân Nhật tràn vào, và với sự can thiệp của Mỹ. Tai ương kinh tế và những tàn khốc chiến tranh diễn ra hằng ngày. Sự vô định về thân phận nước Việt Nam được phản ánh trong đời sống của người dân. Ngay cả trẻ em cũng nếm cảnh chết chóc ngay trước mắt, nhìn những xác chết bị bỏ chơ vơ trên đường và chứng kiến chính thân nhân của mình bị chết trong oanh tạc. Nghiêm Đại Đạo (Glassey-Tranguyen \& Nghiêm, 2000), một chuyên gia ghép thận hàng đầu trên thế giới của Bệnh viện Đại học Pittsburgh, nhớ lại cảnh gia đình ông luôn di chuyển trong những năm đầu đời trong một cuộc phỏng vấn lịch sử truyền khẩu chiều sâuv (phỏng vấn tiếng Anh, tác giả chuyển ngữ):

...Năm 1945, khi quân Nhật xâm chiếm Việt Nam, lúc đó là Đông Dương, gia đình tôi đi ghe từ Campuchia về lại Hà Nội. Chúng tôi trở về ngôi nhà gia tiên, cách vùng Pháp kiểm soát khoảng mười kilômét. Vì không có trường, Bố và chị tôi dạy tôi học. Nhưng Bố tôi bị Pháp bắn chết năm 1948, khi tôi mới bảy tuổi.

(Nguyên văn Anh ngữ: “. . . In 1945, when the Japanese were invading Vietnam or Indochina at the time, we went back to Hà Nội from Cambodia by boat to go faster. We stayed in our birth house, about ten kilometers from the non-controlled French area. There was no school. My Dad and sister taught me as much as they could. But my Dad was killed by the French when they raided us in 1948. I was only seven years old.")

Năm 1954 có thể nói là thời điểm có nhiều xáo trộn nhất. Hiệp định Geneva được ký kết ngày 20 tháng Bảy, năm 1954 đã chia đôi Việt Nam ở vĩ tuyến 17. Tâm thức người Việt bị bấn loạn hơn cả những tang thương trước mắt. Đảng Cộng Sản cướp chính quyền ở miền Bắc, và nước Việt Nam Cộng Hoà được hình thành tại miền Nam. Người Việt ở miền Bắc phải quyết định ở lại hay di cư vào Nam. Hơn hai triệu người đã ra đi. Sự chia cắt và bứng rể của hàng trăm ngàn gia đình của hàng triệu người miền Bắc vẫn còn hoành hành trên đời sống của họ. Nhiều gia đình vẫn chịu cảnh ngăn cách đến hôm nay và chưa bao giờ được đoàn tụ. Robert Nghiêm Nguyễn (Glassey-Tranguyen \& Nguyễn, 2000), Thạc sĩ Nhân chủng học và một người được phỏng vấn trong Dự án VAP, ghi tâm lời Mẹ ông dặn dò trên đường xuôi Nam:

A à ơi, ạ ời ời,

Bồng bồng mẹ bế con đi

Đường xa mẹ có quản chi nhọc nhằn

Yêu con mẹ dặn ân cần

Lớn khôn giữ lấy TINH THẦN VIẸTT NAM

Nối liền một dải Bắc Nam 
Trangdai Glassey-Tranguyen- Biểu Đạt Căn Tính Di Dân trên Quê Huoong Việt-Mỹ và tại Hải Ngoại

Giữ gìn bờ cõi giang san nước nhà...

Bài thơ này đoạt giải Thơ toàn quốc năm 1955 (Glassey-Tranguyen \& Nguyễn, 2000) và được ngâm thường xuyên trên đài truyền thanh của nước Việt Nam Cộng Hoà vì nó gột tả được những ưu tư của khúc quanh lịch sử đó cách mạnh mẽ. Trong khi sự chia cắt đất nước năm 1954 làm vỡ nát tình dân tộc và khơi dậy ước mơ và quyết tâm thống nhất quê hương, chiến tranh Việt Nam làm cho đời sống của người dân trong những vùng tác chiến trên cả nước càng khốn đốn hơn, đưa lưỡi hái của tàn phá lên cả những vùng hậu phương. Cuộc thảm sát Tết Mậu Thân 1968 ở Huế là một đòn chí mạng không ngờ trước được đối với nước Việt Nam Cộng Hoà và người dân. Đây có lẽ là biến cố chính thứ nhì, sau cuộc bỏ phiếu bằng chân của người dân miền Bắc năm 1954, đã làm cho nhiều người dân lưu lạc trong giai đoạn này. Những hồ sơ của chính phủ Mỹ gọi những người Việt chạy loạn Tết Mậu Thân 1968 là 'người tỵ nạn' (refugees ${ }^{\text {vi }}$ ), và các tác phẩm của tác giả Việt Nam như quyển Giải Khăn Sô cho Huếvii của nhà văn Nhã Ca phản ánh những kinh hoàng, đau đớn, và tuyệt vọng của người dân trong biển chết. Tác phẩm này vẫn là tài liệu tham khảo chính cho nhiều người Mỹ gốc Việt về cuộc thảm sát, và được dịch sang tiếng Anh vào tháng Tám năm 2014.

Tôi cho rằng với một lịch sử đầy di tản và lưu lạc như vậy ngay trên quê hương mình ở thế kỷ hai mươi, người Việt đã hình thành và biểu đạt một căn tính di dân refug-endity trước khi Sài Gòn thất thủ tháng Tư năm 1975. Tuy nhiên, mức độ và sự đột ngột của biến cố này đưa refug-endity lên mức độ quốc tế với những biến động tột đỉnh và tâm lý mất phương hướng. Người dân miền Nam ra đi với nhiều xáo trộn, kèm theo một nỗi mất mát to lớn: mất quá khứ cá nhân, mất gia đình, mất quê hương đất nước. Từ năm 1975, nhiều người Việt ra đi với ý nghĩ là mình sẽ không bao giờ được nhìn thấy quê hương lần nữa. Đây có lẽ là niềm mất mát lớn nhất vì tâm tình gắn bó với quê hương xứ sở, với quê cha đất tổ, và với thân bằng quyến thuộc của người Việt. Năm 1975 là một thời điểm mới và một bước ngoặt dứt khoát trong tâm thức di dân của người Việt. Người Việt bị đặt ra ngoài đất nước, không như năm 1954 hay 1968. Nhân diện văn hoá Việt Nam bị thách đố và cọ xát với văn hoá của miền đất tạm dung ở Tây phương. Sự cọ xát này dữ dội hơn cuộc chiến văn hoá trong thời Pháp thuộc hay thời chiến tranh Việt Nam, vì khi những biến cố này xảy ra tại Việt Nam, người Việt có một tinh thần bài ngoại dù có những sự thích ứng bắt buộc. Hơn nữa, môi trường vẫn mang Việt tính, văn hoá chủ lưu tiềm tàng trong đời sống hằng ngày vẫn là văn hoá Việt. Khi người Việt di cư đến thế giới phương Tây và ở ngoài quê hương của mình, họ đối diện với áp lực hội nhập vào xã hội chủ lưu. Tuy quyết tâm và nổ lực giữ gìn văn hoá gốc của người Việt tỵ nạn đã mang lại nhiều kết quả sau bốn thập niên, văn hoá dòng chính không còn là văn hoá Việt. Ở một số nơi tại hải ngoại - như Little Saigon ở Quận Cam - văn hoá Việt xem ra rất nổi trội. Nhưng không hẳn như vậy - vì đó là văn hoá Việt Mỹ, văn hoá Việt trở thành văn hoá 'di dân,' văn hoá sắc tộc, văn hoá thiểu số. Do đó, những nơi này vẫn phải chịu sự chi phối của văn hoá chính ở đất nước tạm dung và cộng đồng người Việt ở Mỹ vẫn phục vụ đồng hương là chính dù có những tương tác liên sắc tộc.

Vì thế, ở năm 1975, căn tính di dân refug-endity của người Việt mang một ý nghĩa mới ở một mức độ di cư mới, vì người Việt đã thực sự lưu vong. Tôi cho rằng cái cảm giác bị chia cắt vĩnh viễn với quê hương mang đến nỗi đau tột đỉnh, vì nó kèm theo sự phân ly với người thân còn ở lại và với nơi chôn nhau cắt rốn, nơi lưu giữ lịch sử cá nhân của họ. Tuy vậy, trong bối cảnh lịch sử Việt Nam cận đại, tôi nhìn vào năm 1954 và 1968 như là khởi điểm cho cuộc xuất hành năm 1975, và là điểm đối chiếu cho nhiều người Việt, nhất là với cuộc di cư vào Nam. Như vậy, có một sự tiếp nối của căn tính di dân refug-endity khởi đi từ giữa thế kỷ hai mươi từ trong nước, và mở rộng ra thế giới năm 1975. Từ cái đứt đoạn Bắc Nam năm 1954, đến cái vỡ nát của 
Trangdai Glassey-Tranguyen- Biểu Đạt Căn Tính Di Dân trên Quê Huơng Việt-Mỹ và tại Hải Ngoại

miền Nam 1975, tâm thức của người dân Việt bị phân tán ở hai mức độ: quốc gia, và quốc tế. Nếu những ai bỏ miền Bắc ra đi năm 1954 đã khóc niềm phân ly ngay cả trước khi họ vào Nam, thì người Việt tỵ nạn sau tháng Tư 1975 đã phải cảm thấy lưu luyến quê hương đến chừng nào khi đã phải lìa bỏ đất nước trong đau đớn và cấp bách.

Ôn lại giai đoạn lịch sử trước và sau 1975 ở Việt Nam làm chảy máu những vết thương còn mưng mủ. Khi quân đội Hoa Kỳ rút khỏi Sài Gòn, bỏ mặc miền Nam rơi vào tay Cộng Sản, những ai đã bỏ miền Bắc năm 19754 đã lập tức ra đi lần nữa, vì họ đã từng chịu sự tàn ác của gọng kiềm Cộng Sản ở ngoài Bắc. Ly hương cách bất ngờ và đột ngột năm 1975 đã là một cú sốc cho biết bao người, ngay cả nhiều năm sau cuộc tản cư vĩ đại đó. Có nhiều người rời Việt Nam trước khi Saigon thất thủ qua sự sắp xếp của các sở Mỹ, nhưng họ cũng ra đi với không ít sự kinh ngạc. Bác sĩ Vũ Thiên Nữ (Glassey-Tranguyen \& Vũ, 2000), một giáo sư y khoa tại Đại học San Francisco và Trưởng trung tâm Chuyên Phổi tại Bệnh viện San Francisco đã thuật lại (phỏng vấn tiếng Anh, tác gỉa chuyển ngữ),

...Gia đình tôi rời Việt Nam ngày 23 tháng Tư, năm 1975. Bố tôi lúc ấy làm việc cho Bank of America. Trước đó, họ đã báo cho tất cả nhân viên và gia đình chuẩn bị để xuất ngoại bất cứ lúc nào. Gia đình tôi không bao giờ nghĩ mọi việc lại diễn ra như thế. Khi chúng tôi thực sự ra đi, Mẹ tôi lo nhiều vì Bố Mẹ tôi lo lắng về tương lai của sáu đứa con, lại bỏ quê hương xứ sở mà đến một đất nước mới, tương lai mờ mịt. (Nguyên văn Anh ngữ: “. . . My family left on the 23rd of April, 1975. At the time, my Dad worked for Bank of America who told us to ready ourselves to leave the country any minute. But we never thought that it would happen. When we were actually leaving for America, my Mom got very worried because it's a big deal for my parents with six kids to leave home for a new country, not speaking the language, not knowing what would happen.")

Nhiều người đã bị kẹt lại, phải chịu đựng những hệ quả hậu chiến và cam chịu nhiều áp bức về mặt xã hội chính trị. Chế độ Cộng Sản truy sát và bắt giam các chuyên gia, văn nghệ sĩ, các vị lãnh đạo tôn giáo, và các cựu quân nhân của Việt Nam Cộng Hoà ở một nơi mà giảo ngôn của chính quyền mới gọi là 'trại cải tạo.' Những trại này tương đương với những trại tập trung của Hitler trong âm mưu hạ nhục nhân phẩm và ý đồ hủy diệt con người. Chế độ chuyên quyền còn đẩy hàng triệu người Việt ra khỏi đất nước, khởi đầu với phong trào vượt biển vào cuối thập niên 1970, khi thuyền nhân Việt Nam lập tức thu hút sự quan tâm, lòng thông cảm, và sự hỗ trợ của quốc tế. Nhiều người khác đã trốn khỏi Việt Nam bằng đường bộ đến những nước lân bang như Lào, Thái Lan, và Cambốt, đi tìm tự do. Những khốn khó trên cạn hay dưới bể đều chí tử, rào trói người tỵ nạn vào vòng vây của tử thần và nguy cơ bị tấn công. Anh Paul Nguyễn (Glassey-Tranguyen \& Nguyễn, 2000b) ở Huntington Beach đã liên tưởng cuộc vượt biên đường bộ sang Cambốt của mẹ và chị gái mình với việc canh cánh sợ quân thổ phỉ và sự đàn áp của quân đội Miên. Những ai vượt biển đều phải gánh chịu những mạo hiểm như thuyền chật hẹp, thời tiết nguy hiểm, thiếu lương thực, và bị hải tặc Thái Lan tấn công. Người ta ước đoán rằng hơn phân nửa thuyền nhân đã đắm mình giữa biển khơi. Nhiều phụ nữ đã bị hải tặc Thái Lan cưỡng hiếp và bắt đi, và vĩnh viễn là những thành viên bị mất tích của cộng đồng Việt hải ngoại. Cô Ann Phong (Glassey-Tranguyen \& Phong, 2000) ở Cerritos, một danh họa với nhiều đề tài và 
Trangdai Glassey-Tranguyen- Biểu Đạt Căn Tính Di Dân trên Quê Huoong Việt-Mỹ và tại Hải Ngoại

phong cách mới mẻ, đã trải qua nhiều năm để giải tỏa sự vô vọng trên biển cả và những đau đớn sau khi sống sót. Phong dùng nghệ thuật như một phương thức chữa lành để giảm bớt những ai oán mình đã trải qua, cũng như để khẳng định nhân diện của mình (Glassey-Tranguyen, 2011a) (phỏng vấn tiếng Anh, tác giả chuyển ngữ),

. . . Những ngày sống trong trại tị nạn, nghe chuyện những nữ thuyền nhân bị hãm hiếp cướp bóc, tôi đau buồn vô cùng. Nó vẫn đeo đuồi tôi và tác động đến việc sáng tạo của tôi. Hãm hiếp, cướp bóc, và biển đen. Sau bốn ngày đêm cập bến, trời vẫn không trăng sao. Nhìn ra biển thật hãi hùng. Chỉ thấy một màu đen.

(Nguyên văn Anh ngữ: “. . . Living in the refugee camp, listening to the Vietnamese women who were raped and robbed, was a down point of my life. They still influence me today in my art. The rape, the robbing, the darkness of the ocean. Because after four days and nights when I went up to the shore, there was no moon, no stars, nothing. To look at the ocean was so scary. You saw black.")

Đến năm 1986, mọi người Việt Nam tỵ nạn đều được định cư ở một nước thứ ba. Tuy nhiên, không phải ai cũng được cho đi định cư kể từ thời điểm đó. Nhiều người bị cưỡng bức hồi hương, và rất nhiều người đã tự tử, lập lại tiêu chí của những ai muốn rời khỏi Việt Nam bằng mọi giá, "Thà chết chứ không chấp nhận Cộng Sản" (nguyên văn: "Death rather than Red"). Những người còn lại sống lây lất, không giấy tờ ở những trại tự lực cánh sinh. Khi Cao Uỷ Ty. Nạn Liên Hiệp Quốc (UNHCR) chận đứng làn sóng tỵ nạn ở Đông Nam Á năm 1996 (Indonesia đóng cửa trại tỵ nạn thuyền nhân Việt Nam ở Galang năm 1996; Thái Lan năm 1997; Philippines năm 1997; Hồng Kông năm 2000. Năm 2001, Cao ủy Tỵ nạn Liên hiệp quốc chính thức dẹp bỏ trại tỵ nạn cuối cùng cho thuyền nhân ở Malaysia, chấm dứt 21 năm Cao ủy Tỵ nạn hợp tác ở nước này để giúp thuyền nhân người Việt), khoảng 2,000 thuyền nhân người Việt tại Phi trở nên những người vô quốc gia. Cộng đồng người Việt hải ngoại đã tỏ tình liên đới, và vận động để giúp họ định cư. 2,000 người Việt này là thành viên của nhiều gia đình đang bị phân ly, và thân nhân cũng như đồng hương đã lập tức đáp lại sự kêu gọi sự hỗ trợ về tiếng nói chính trị và tài chính. Đến hôm nay, nhiều người Việt tỵ nạn vẫn sống trong quên lãng và sẽ chịu cảnh lưu linh hoặc vô quốc gia trọn đời. Căn tính di dân refug-endity của người Việt, do đó, vẫn còn là một thực tế phức tạp và mở ngõ trong hoàn cản toàn cầu hiện nay.

Cuộc di tản năm 1975 và những làn sóng tỵ nạn sau đó đã giúp người Việt hiểu biết trọn vẹn hơn về sắc tộc của chính mình, và ý thức rõ ràng hơn về chỗ đứng của họ như những thành viên trong cộng đồng thế giới khi họ định cư trên khắp thế giới. Tại Mỹ, họ được đưa vào các trại tỵ nạn như Camp Pendleton ở San Diego, và sau đó được đi định cư khi có sự bảo trợ của một cá nhân hay các tổ chức tôn giáo. Vì kinh nghiệm chiến tranh và di dân của mình, những người tỵ nạn vẫn đối diện với những khó khăn tâm lý hậu chấn, cảm nhận cùng một lúc sự mất mát quê nhà, tổ quốc, gia đình, và chính mình. Thực tế thô nhám của trại tỵ nạn ảnh hưởng mạnh đến trại viên, vạch trần cái cảm giác bị hạ thấp, cái cảm giác không còn là người, như thi sĩ Du Tử Lê (Glassey-Tranguyen \& Du Tử Lê, 2002) đã phác họa trong trích đoạn sau đây (Du Tử Lê, 1987):

cám ơn

cám ơn Pendleton

đã cho ta túp lều 
Trangdai Glassey-Tranguyen- Biểu Đạt Căn Tính Di Dân trên Quê Huoong Việt-Mỹ và tại Hải Ngoại

chui ra chui vào

thập thò và rụt rè

như một con chuột da vàng

với một óc rỗng không

và đôi tay thừa thãi

Tôi muốn hỏi: Kinh nghiệm di cư vào Nam năm 1954 và hoài niệm về nó đã đồng âm với những tâm tình của cuộc xuất hành năm 1975 như thế nào? Khi đối chiếu một tác phẩm về kinh nghiệm xuôi Nam 1954 với một tác phẩm về kinh nghiệm di tản 1975, chúng ta có thể nhận thức được sự tiếp nối mà qua đó, hình ảnh người tỵ nạn được kiến tạo, diễn đạt, và phân tích. Tác phẩm Đêm Giã Tù Hà Nộ iviii của cố nhà văn trứ danh Mai Thảo được nhà xuất bản Người Việt phát hành tại Sài Gòn năm 1955, và được tái bản và nhắc đến nhiều trên quê hương Việt-Mỹ VietnAmerica vì nó diễn đạt được cái đau đớn khi lìa xa gia đình và quê quán - cả hai đều thiêng liêng trong tâm tình văn hoá Việt Nam. Mai Thảo rời Hà Nội năm 1954 khi Việt Nam bị chia đôi ở Vĩ tuyến 17, sau nhiều năm tham gia kháng chiến chống Pháp để giành độc lập cho quê hương từ năm 1948. Chọn lựa di cư về miền Nam của ông rất rõ ràng và dứt khoát, một sự chia tay với quá khứ và tất cả những dối trá của nó. Ông viết:

Phượng nhìn xuống vực thẳm.

Hà Nội ở dưới ấy.

Từ chỗ anh đứng, Phượng nhìn sang bờ đường bên kia. Những tảng bóng tối đã đặc lại thành khối hình. Từng chiếc một, những hàng mái Hà Nội nhoà dần. Phượng nhìn lên những hàng mái cũ kỹ, đau yếu ấy, giữa một phút giây nhoè nhạt, anh cảm thấy chúng chứa đựng rất nhiều tâm sự, rất nhiều nỗi niềm. Những tâm sự câm lặng. Những nỗi niềm nghẹn uất. Của Hà Nội. Của anh nữa.

Dưới những hàng mái cong trũng, ngập đầy lá mùa kia, đang xảy ra những tâm trạng, những biến đổi gì mà ở bên này đường Phượng không đoán hiểu được. Hà Nội đang đồi màu. Đứng bên này bờ đường nhìn sang, Phượng bắt đầu tiếp nhận với một thứ cảm giác ớn lạnh, cách biệt, anh đã đứng trên một bờ vĩ tuyến mà nhìn về một vĩ tuyến bên kia. Bên ấy, có những hình ảnh chia cắt, đứt đoạn. Bên ấy, có những hình chiến luỹ, những hàng rào dây thép gai, những đoạn đường cấm, những vùng không người.

Phượng cũng không hiểu tại sao nữa. Giờ này anh còn là người của Hà Nội, thở nhịp thở của Hà Nội, đau niềm đau của Hà Nội, mà Hà Nội hình như đã ở bên kia.

Mai Thảo diễn đạt tâm trạng của một người tỵ nạn, dù chưa xa nơi chôn nhau cắt rốn đã cảm nhận hết những sự ghẻ lạnh và khoảng cách đối với nơi ấy. Cảm giác không còn thuộc về Hà Nội của ông có nhiều giai tầng, nhưng sự khác biệt về chính kiến là nổi trội nhất. Ông viết, cũng trong truyện ngắn về đêm ông rời Hà Nội $i^{\text {ix }}$,

Đứng một mình trong đêm dài, trước một Hà Nội ngủ thiếp, Phượng nghĩ đến những người bạn đường đã vượt Hồng Hà, đã bỏ Hà Nội, bỏ đất Bắc trước anh, vượt vĩ tuyến về tiếp tục cuộc đấu tranh cho tự do, cho con người, trên phần đất nước còn lại. Anh biết rằng thời đại, trong ngày tới sẽ nối kết con người bằng một ý niệm một hệ thống tự do. Tâm trạng của Phượng đêm nay cũng là tâm trạng của một người thợ máy Đức, một người dân cầy Triều Tiên, đang ngày đêm vượt khỏi những vĩ tuyến tù đày để tìm một hướng đi, một chân trời có không khí và ánh sáng. 
Trangdai Glassey-Tranguyen- Biểu Đạt Căn Tính Di Dân trên Quê Huoong Việt-Mỹ và tại Hải Ngoại

Cái chính kiến chọn tự do thay vì độc tài toàn trị là điểm chung của tất cả những ai di cư vào Nam năm 1954, cũng như cho rất nhiều người đã ra đi từ mọi miền Việt Nam sau 1975. Chiều kích chính trị của căn tính di dân refug-endity có lẽ là chủ đề nổi bật nhất trong kinh nghiệm của người Việt hải ngoại, với tiền đề là sự kết thúc vô chung của cuộc chiến Việt Nam năm 1975. Trong trích đoạn bài thơ của Du Tử Lê, người tỵ nạn cảm thấy bị hạ xuống thành "một con chuột da vàng" vô dụng - một cái nhìn rất khác với cách định hướng của Mai Thảo về người tỵ nạn, vốn coi cuộc di cư của mình như một hành trình đi vào ánh sáng và tự do. Người tỵ nạn trong cả Mai Thảo và Du Tử Lê có chung một mục đích: rời bỏ quê quán hoặc quê hương để đi tìm tự do. Tuy nhiên, sự khác biệt là với Du Tử Lê, người tỵ nạn Việt Nam giờ đây bị hất tung vào bối cảnh toàn cầu, vào một không gian ở ngoài Việt Nam. Mai Thảo viết qua giọng của một người thứ ba, qua nhân vật tiểu thuyết tên Phượng. Du Tử Lê nói trực tiếp từ kinh nghiệm của mình qua đại từ "tôi," và một cách nào đó, cho thấy refug-endity mang tính cá nhân hơn đối với người Việt vào năm 1975. Hơn nữa, dù Phượng cảm thấy một tình liên đới với những người đang đi tìm tự do khác trên thế giới, anh vẫn đang ở trên mảnh đất quê hương. Cái ý thức liên quốc gia ấy chỉ làm cho anh thêm mạnh mẽ, vững tin vào chọn lựa của mình và tương lai phía trước. Đó là tâm tình của người Việt rời Bắc vào Nam. Trong khi Phượng đau đớn chia lìa Hà Nội, anh ra đi với tâm trạng đầy hy vọng, đi về vùng sáng, đi về miền tự do. Còn người Việt ly hương năm 1975 đã ra đi - vẫn đi tìm tự do - nhưng với tâm trạng ly hương, mất mát khôn cùng. Cái cảm giác mất mát khi ly hương còn gắn liền với nỗi đau mất quê hương miền Nam ngày 30 tháng Tư, 1975. Lần này, người Việt rời quê hương để đi vào thế giới, thì tuy họ cũng đi tìm "một chân trời có không khí và ánh sáng" (nói theo kiểu Mai Thảo), nhưng nỗi đau chia lìa quê hương đã phủ lấp bất cứ một vùng sáng nào.

\section{TỰ PHÁT, Tự LỰC SÁC TộC}

Từ khi đến Mỹ tháng Năm năm 1975, người Việt tỵ nạn và di dân ${ }^{x}$ đã tận dụng quyền tự do ngôn luận và những điều kiện có sẵn để xuất bản các sáng tác của mình, ban đầu qua việc in ấn, truyền thông, và về sau là qua mạng điện toán. Những tác phẩm này bao gồm tin tức liên quan đến cộng đồng tỵ nạn và những đề tài phản ánh kinh nghiệm Việt Mỹ, với các tác giả đã thành danh cũng như những người mới cầm bút. Trong bài này, tôi chọn chú trọng vào Quận-Cam-da-vàng (Vietnamese Orange County) vì những lý do sau đây. Thứ nhất, tuy tôi đã xuất bản nhiều tác phẩm tiếng Việt tại Canada và nhiều nước Châu Âu và Châu Á trong hai mươi mốt năm qua, tôi hiểu về cộng đồng người Mỹ gốc Việt tại Quận Cam, California, rõ hơn bất cứ nơi nào khác, vì đây là nơi tôi sinh sống và nghiên cứu trong hơn hai thập niên. Thứ hai, đây là chọn lựa thích hợp vì Quận Cam đóng vai trò tiên phong trong nhiều việc trong cộng đồng hải ngoại, và là nơi tập trung người Việt đông nhất ở ngoài Việt Nam. Thứ ba, tôi không thể nào thảo luận cách đầy đủ khung cảnh văn chương Việt toàn cầu trong bài viết này - nên tôi bắt buộc phải chọn một địa điểm nhất định - tuy tôi sẽ hướng đến một cái nhìn về căn tính di dân refug-endity trong bối cảnh liên quốc gia của thế kỷ hai mươi trong phần kế tiếp về những biểu hiện toàn cầu. Tuy vậy, những thảo luận tôi đưa ra về Quận-Cam-da-vàng và quê hương Việt-Mỹ VietnAmerica đến từ việc phân tích đối chiếu về những mối liên hệ của người Việt hải ngoại trong các cuộc nghiên cứu đa quốc gia tôi đã thực hiện tại Bắc Mỹ, Châu Âu, Úc Châu, và Á Châu.

Vì những hoàn cảnh đưa đến sự hình thành của cộng đồng Việt hải ngoại năm 1975, lòng yêu nước là một trong các mạch quan trọng chảy sâu trong refug-endity - được cảm nhận và diễn 
Trangdai Glassey-Tranguyen- Biểu Đạt Căn Tính Di Dân trên Quê Huoong Việt-Mỹ và tại Hải Ngoại

đạt qua nhiều cách - nhưng lòng yêu nước đó có thể được thấy rõ rệt nhất trong nền chính trị liên quốc gia của người Việt hải ngoại. Ngay từ khi mới đến, người Việt tỵ nạn nắm bắt tự do mới tìm được trong việc xuất bản như một phần của tự do ngôn luận tại Mỹ. Những ai đã từng sống dưới chế độ Cộng Sản hậu 1975 đặc biệt trân trọng tự do phát biểu trên miền đất mới. Sự tập trung đông đảo của người Việt tại Quận Cam, California, Hoa Kỳ, tạo ra nhiều cơ hội cho người cầm bút và độc giả, và giúp hình thành một môi trường chữ nghĩa không nơi nào khác tại hải ngoại có thể sánh kịp. Những thể loại sáng tác - từ thơ, tiểu thuyết, tạp chí văn chương, đến truyền thông in và phát sóng - cùng phát triển và hỗ tương cho nhau. Như ở các nơi khác tại hải ngoại, phần lớn các chủ bút của hệ thống truyền thông tiếng Việt tại Little Saigon, Quận Cam, là những tác giả có tiếng trước 1975 tại miền Nam. Tiếng Việt đóng vai trò chính trong sự phát triển về truyền thông. Qua tiếng mẹ đẻ, người Việt tỵ nạn quây quần, tiếp tục công việc chữ nghĩa đã có từ miền Nam, xây dựng cộng đồng, và tạo ra những vận hội mới. Nền văn chương tiếng Việt tại hải ngoại này được tiếp cận dễ dàng hơn trên toàn thế giới nhờ mạng điện toán trong mười lăm năm qua.

Trong tinh thần dân chủ, tôi ghi nhận những nổ lực, sự góp mặt, và đóng góp của tất cả các tác giả trong dòng văn học hải ngoại. Tuy nhiên, tôi cho rằng những tác giả thành danh và tận hiến đời mình cho chữ nghĩa - nhiều vị trong số họ không còn nữa - đã cho ra đời những tác phẩm có tính quyết định để tạo nên căn tính refug-endity của người Việt vì khả năng chuyển tải những kinh nghiệm và cái nhìn thực tế một cách mãnh liệt nhất. Những tác giả thành danh tiếp tục công việc họ đã gầy dựng ở miền Nam trước 1975, mời bạn bè từ các nước khác như Canada và Châu Âu về Quận Cam để cùng nhau mở ra một khung cảnh văn chương và truyền thông mới tại Mỹ. Họ tạo ra một không gian tự phát và tự lực, và từ đó tiến đến giai đoạn mới là hội nhập vào dòng chính - cho dù vẫn giữ tiếng Việt là ngôn ngữ chính - qua những xuất bản trên mạng, blogs, phát hành qua amazon, dịch sách qua tiếng Anh, vân vân. Những tác giả này tạo ra một không gian để phản ánh kinh nghiệm và cái nhìn của chính họ, cũng như nhân sinh quan của đồng bào và cộng đồng văn hoá của họ về đời sống tại Hoa Kỳ và hải ngoại. Không những chủ động, những người cầm bút xông pha vào hết mọi sinh hoạt chữ nghĩa: tự xuất bản, thành lập các hội văn bút, lập các nhà xuất bản và chương trình sáng tác, thiết lập các hệ thống truyền thông và tạp chí văn chương, tiếp tục những công việc từ trước 1975 ở miền Nam, và giúp tạo ra một máng chuyển thông giữa văn chương 'tỵ nạn' của người Mỹ gốc Việt với văn chương bắt cầu của những thế hệ sinh trưởng tại Mỹ từ thế hệ 1.5 trở đi.

\section{Refug-endity: Sự Tụ̣ Lập Xuyên Quốc Gia và Tâm Tình Văn Hoá}

Giữa môi trường văn chương mới, truyền thông tiếng Việt đóng một vai trò thiết yếu trong việc cung cấp tin tức và tạo ảnh hưởng trên cộng đồng Việt Mỹ về những vấn đề cấp bách, cũng như khuyến khích những sáng tác mới nói về refug-endity và rộng hơn. Hệ thống truyền thông tiếng Việt ngày càng mở rộng tại Quận Cam là một chứng minh thực tế rằng truyền thông chính là 'đệ tứ quyền,' nơi cộng đồng quây quần, đối thoại, tranh luận, và trao đổi thông tin. Vì vai trò truyền thống và tính khả thi của nó vào cuối thập niên 1970s, báo chí in của người Mỹ gốc Việt đóng một vai trò đặc biệt và quan trọng vì nó đề xướng, duy trì, và mở rộng việc viết tiếng Việt ngay từ ngày đầu của cộng đồng trong mọi lãnh vực xã hội, không chỉ riêng với người cầm bút. Những tờ nhật báo tổ chức các cuộc thi viết bằng tiếng Việt để lôi kéo độc giả tham gia viết và để tìm tài năng mới, như Viết Về Nước Mỹ của Nhật báo Việt Báo, Câu Chuyện Người Vợ Tù Cải Tạo của Nhật báo Viễn Đông, và nhiều cuộc thi viết theo chủ đề của Nhật báo Người Việt. Tương tự, từ ban đầu, truyền thông phát sóng tiếng Việt cung cấp những chương trình giải trí và 
Trangdai Glassey-Tranguyen- Biểu Đạt Căn Tính Di Dân trên Quê Huoong Việt-Mỹ và tại Hải Ngoại

trình diễn tuy giới hạn nhưng được cảm kích thưởng ngoạn; và ở thập niên 2010 đã bừng nở những khung trời mới và được đa dạng hoá với những đài có trụ sở tại Quận Cam nhưng với hệ thống phát sóng khắp nước Mỹ và Úc Châu. Những chương trình có ảnh hưởng trực tiếp đối với cộng đồng tiếp tục phát triển mạnh, với những shows phục vụ cho thế hệ ngoại biên trên đà tăng nhanh trong những năm gần đây.

Sự tự lập sắc tộc này được mở rộng đến những ai còn sống ở Việt Nam và không có tự do xuất bản các sáng tác của họ hay được quyền bày tỏ quan điểm, cũng như những ai sống tại các nước khác trong cộng đồng hải ngoại mà điều kiện xuất bản và lượng độc giả không thuận lợi như ở Quận Cam. Việc mở rộng tính tự lập này đến những người cầm bút đang sống tại Việt Nam đã làm cho Việt Nam mang tính hải ngoại trong ý nghĩa thực nhấtxi và thách thức những biên giới thường được cho là hiện hữu giữa Việt Nam và thế giới Việt hải ngoại. Việc mở rộng này vẫn còn mạnh mẽ và cần thiết cho đến hôm nay - bốn mươi năm từ khởi nguyên của cộng đồng Việt Nam hải ngoại, và phức tạp hoá những biểu đạt về 'quê nhà/quê hương,' một chủ đề nổi trội trong refug-endity căn tính di dân Việt. Quê hương/quê nhà đã và đang là Việt Nam, và cũng là hải ngoại nữa. Cái khái niệm 'nhà' và niềm thao thức về một quê hương cho thấy 'nhà' là một thực thể ở ngoài cái nơi một con người hiện hữu trên bản đồ. Vai trò của cộng đồng văn hoá trên quê hương Việt-Mỹ VietnAmerica có ảnh hưởng sâu đậm trên kinh nghiệm của người di dân và tỵ nạn, tạo ra một không gian vừa hữu thể vừa vô hình cho việc (tái) xây dựng một ngôi nhà trong quá khứ và một ngôi nhà mới liên quốc gia. Cái nơi chốn đã một thời là nhà đối với người Việt hải ngoại vẫn còn là nhà trong lòng họ. Họ vẫn chịu lực hút của dãy đất dọc theo Biển Đông, cái nơi họ yêu thương và gắn bó. Những ai chào đời và lớn lên ở Việt Nam thường cảm thấy gắn bó với nơi chôn nhau cắt rốn; đây là tác động của quá trình khai mở tâm thức được kết tụ trong việc di dân và hội nhập văn hoá.

Cấu trúc xã hội của sắc tộc gột tả sức mạnh uẩn áo của việc dấn thân văn hoá. Diễn đạt văn chương là một không gian quen thuộc giúp kinh nghiệm này nhuận sắc. Ngôi nhà xưa không còn xa xôi nữa khi người ta tìm ra cách giữ gìn nó trong ngôi nhà mới, ngay cả khi chỉ qua kỷ niệm, như nhà văn được nhiều người kính trọng và Chủ bút Phạm Phú Minh (Glassey-Tranguyen \& Phạm, 1999) nói về chuyến thăm Hà Nội lần đầu của ông:

. . . Năm 1989 là lần đầu tiên Chú đi tới Hà Nội. Thì Chú thích lắm! Thú vị lắm! Và cũng vì cái thú vị đó mà khi về Sài Gòn sau một tháng ở Hà Nội, Chú bắt đầu viết một cái hồi ký về chuyến đi đó... Trong số báo Người Việt Xuân 1980 có đăng bài đó, là "Hà Nội Trong Mắt Tôi” của Phạm Xuân Đài.

Giống như 'quê nhà,' văn hoá - tiềm tàng hay linh hoạt - vẫn chảy trong máu. Có một số người Mỹ gốc Việt thế hệ thứ nhất cho rằng những thế hệ sau đã hoàn toàn phá sản về ngôn ngữ và văn hoá gốc, nhưng cái nhìn này có thể sai lệch. Thế hệ tỵ nạn muốn con cháu giữ căn tính văn hoá, nhưng điều cần lưu ý là chính thế hệ 1.5 và các thế hệ tiếp theo phải vật lộn với nhiều thử thách để gìn giữ kiến thức văn hoá rất giới hạn của mình trong khi bị chi phối bởi nhu cầu hội nhập với dòng chính. Họ nhận ra rằng hệ thống giá trị có thể được chia sẻ xuyên qua lằn ranh sắc tộc, nhưng cần được gắn liền với văn hoá gốc của mối người. Biết nguồn gốc của mình mang đến những ích lợi cho sự phát triển tâm lý của một cá nhân. Nghệ sĩ thu âm và nhạc sĩ Simon Levan (Glassey-Tranguyen \& Levan, 2000) nói về thao thức của anh muốn chia sẻ những giá trị trong văn hoá của mình đến người khác. Đặt tên cho phòng thu của mình tại Little Saigon, Quận Cam, là "Song Lang," một nhạc cụ Việt Nam cổ truyền dùng để giữ phách, Levan phản ánh (phỏng vấn tiếng Anh, tác giả chuyển ngữ), “...Simon thấy rằng mình muốn dùng âm nhạc để tạo 
Trangdai Glassey-Tranguyen- Biểu Đạt Căn Tính Di Dân trên Quê Huơng Việt-Mỹ và tại Hải Ngoại

nên một thế giới mà trong đó Simon có thể giúp các bạn trẻ nhận ra tình thương và giá trị của gia đình. Điều đó đúng với mọi văn hóa." (Nguyên văn Anh ngữ: "I realized that I wanted to use music as a part of a world where I can help the youth at risk and show them what is love, and the value of a family. That goes to any culture.")

\section{Refug-endity: Những Đề Tài Khác Nhau Trong Một Diễn Đàn Dân Chủ}

Tính tự lực tự phát trong diễn đạt sáng tạo và những xuất bản nhiều thể loại khiến Quận Cam trở nên một phòng thí nghiệm mở rộng và phức tạp, với những tiếng nói quen thuộc và mới mẻ cùng tồn tại, những chiều hướng khác nhau giao thoa, và những khuynh hướng đối lập gặp gỡ nhau. Tôi xin nhấn mạnh rằng tính tự lập này là chủ chốt và quan trọng trong việc phát triển QuậnCam-da-vàng và quê hương Việt-Mỹ, bởi những không gian sắc tộc này mang tính phân hoá cao vì những cái nhìn và khuynh hướng đa dạng tất yếu. Một số cá nhân sẽ có nhiều lợi thế để thực thi sự tự lập tự phát của mình hơn là những người khác, một là vì những quan hệ xã hội và gia thế trước 1975 ở miền Nam, và/hoặc họ hội nhập thành công vào xã hội Hoa Kỳ. Do đó, việc áp dụng tính tự lực tự phát xảy ra không đồng đều và khác biệt tuỳ theo thành phần xã hội. Một số công việc cũng có nhiều thuận lợi cho việc áp dụng này hơn so với những việc khác về mặt ảnh hưởng xã hội - chẳng hạn như thế giới truyền thông và xuất bản - nhưng mỗi cá nhân có một quyền bình đẳng và cơ hội tương đối để thể hiện chính mình. Tôi có được cái nhìn này từ cuộc nghiên cứu tiên phong với Dự án Việt Mỹ (Vietnamese American Project) ${ }^{x i i}$ VAP, mà tôi đã sáng lập từ thập niên 1990 tại California State University, Fullerton. Những chứng từ lịch sử truyền khẩu từ Dự án VAP tạo nên một diễn đàn mở rộng và dân chủ, đưa những tiếng nói của người Việt tại Quận Cam thuộc mọi thành phần xã hội đến với nhau. Khi những chứng từ ngôi thứ nhất này - đôi khi đối nghịch - nằm song song và gặp gỡ nhau, chúng giúp củng cố sự bình đẳng của tính tự lực và tự phát cho những biểu đạt trong cộng đồng.

Trong phần tiếp theo, tôi chọn một số thí dụ điển hình để đưa ra những đề tài lớn trong refug-endity trên quê hương Việt-Mỹ VietnAmerica qua việc thực thi tinh thần tự lực tự phát. Những thể loại thường thấy bao gồm hồi ký, tiểu thuyết, phóng sự, thơ, và những sáng tác kết hợp các thể loại này. Vì nhiều người tỵ nạn có cảm hứng để viết, vẽ, hay soạn nhạc trên đường rời quê hương và/hoặc trong lúc ở trại tỵ nạn, sự phong phú của những tác phẩm này chuyển tải trực tiếp hoàn cảnh của họ và nhanh chóng chinh phục trái tim của đồng bào họ. Những sáng tác này vẫn còn là 'kinh điển' trong căn tính di dân refug-endity vì chúng gợi lên một thời điểm nhất định vốn quen thuộc và thẳm sâu trong tiềm thức của người tỵ nạn. Trong những năm sau 1975, những bài hát như bài "Vĩnh Biệt Sài Gòn" của $\mathrm{MC}$ và nhà hoạt động Nam Lộc, bài "Biển Nhớ" của cố nhạc sĩ Trịnh Công Sơn xiii đánh động trái tim của những người tỵ nạn mới định cư. "Vĩnh Biệt Sài Gòn" kể lại việc ly hương đột ngột và ngoài ý muốn từ thủ đô thân yêu của miền Nam. "Biển Nhớ" luôn được hát lên khi có người rời trại tỵ nạn trong thời gian đó. Tuy những bài hát này vẫn còn được yêu thích hôm nay, khoảng cách thời gian và việc ổn định chỗ ở (và ngay cả một quê hương bất chính thức như VietnAmercia) tại Hoa Kỳ và tại hải ngoại khiến cho những bài hát này mang tính hoài niệm và gây xúc động cho người nghe, hơn là diễn đạt sự cấp bách của thưở nào.

\section{Refug-endity: Tâm thức Sắc tộc Cộng thông qua Âm Nhạc}

Âm nhạc đóng một vai trò độc nhất trong đời sống hằng ngày trên quê hương Việt-Mỹ. Đây là một sự mở rộng của vai trò âm nhạc trong đời sống văn hoá tại Việt Nam, khi mọi người dân 
Trangdai Glassey-Tranguyen- Biểu Đạt Căn Tính Di Dân trên Quê Huoong Việt-Mỹ và tại Hải Ngoại

trình bày và thưởng thức nghệ thuật âm nhạc, từ những người nông dân hát hò trong lúc làm ruộng đến những nghệ nhân trình diễn trong cung đình. Điều này giúp giải thích tại sao ngành kinh doanh âm nhạc tiếp tục nở rộ tại hải ngoại trong bốn mươi năm qua. Những bài hát nói lên kinh nghiệm của người Việt trên quê hương, trên biển cả, và tại hải ngoại chiếm một vị trí đặc biệt trong lòng người nghe, và vẫn còn quan trọng sau nhiều năm với sức hút tình cảm và văn hoá. Thí dụ, những bài hát của cố nhạc sĩ Trầm Tử Thiêng (1937-2000) đặc biệt được yêu thích vì lý do này. Đời sống Việt chảy thấu qua dòng nhạc của ông. Cách ông thể hiện nỗi cô đơn của một trái tim Việt Nam xa nhà đã làm cho bất cứ trái tim người Việt hải ngoại nào rung cảm. Qua những bài hát của ông, người nghe mang kiếp lưu vong trọn vẹn - trong tâm lý, tình cảm, trong sự không nhà, qua khác biệt sinh thái, ngôn ngữ, văn hóa. Được biết đến qua những ca khúc cần kíp về những vấn nạn liên quan đến dân Việt và đất Việt, chẳng hạn như vấn đề thuyền nhân và tưởng niệm miền Nam thất thủ, Trầm Tử Thiêng được trân quý và cảm kích vì ông đã diễn đạt thấu đáo tâm thức và niềm hy vọng của dân tộc Việt Nam. Sao mà dòng nhạc của ông có thể bày tỏ tiếng nói và kinh nghiệm của biết bao người đến vậy! Trong khi đại đa số người Việt coi ông là một danh tài âm nhạc, tôi tìm thấy ở ông một người thực sự dấn thân trong nhiều cách. Khi ông khơi gọi tâm tình và tấm lòng Việt Nam để hỗ trợ cho đồng bào thuyền nhân qua ca khúc "Bên Em Đang Có Ta," hay trong bài "Một Ngày Việt Nam," người nhạc sĩ được ái mộ này đã giúp định nghĩa con đường tương lai cho đồng bào của ông. Ông mở ra một cánh cửa trong một giai đoạn tối tăm vô hướng, soi rọi một lối về.

Một bài hát khác đặc biệt được yêu chuộng của ông mang tên "Một Đời Áo Mẹ Áo Em," vốn lược lại gia phả của phụ nữ Việt Nam, một lịch sử đầy tang thương và chiến tranh. Nhưng trong điệu nhạc suy tư và tha thiết ấy, là một đời sống trỗi lên từ vũng tối của mọi chết chóc một thiếu nữ dậy thì, tình yêu rạo rực của cô dâu mới kết hôn, nỗi hân hoan của lần đầu tiên làm mẹ - tất cả được biểu lộ qua những màu áo theo từng chu kỳ của đời sống. Trước hết, là cuộc sống. Là niềm vui. Là sự mong ngóng. Rồi thì chết chóc lây lan. Có niềm đau. Có thực tế. Người phụ nữ Việt Nam sẽ đắm mình trong dòng Hát Giang để không cho phép kẻ ngoại xâm chạm đến mình, như hai nữ anh hào Bà Trưng Bà Triệu. Người phụ nữ Việt Nam sẽ phải đính khăn tang trên đầu mình để tưởng niệm cái chết của cha, của chồng, của anh, của con. Nhưng người phụ nữ Việt Nam sẽ tiếp tục sống, ngay cả trong ánh dương cuối cùng của hoàng hôn, khi tim nàng đã ngưng đập để hòa với trái tim câm lặng của người yêu dấu trong nấm mộ đất mới đắp. Nhưng hơn tất cả, người phụ nữ Việt Nam sẽ sống - cho dù áo nàng có phai màu, hãy cứ để cho nó nhạt phai.

\section{Chiến tranh, Hy vọng, và Hồi ức trên quê hương Việt-Mỹ}

Hồi ức về một quê hương Việt Nam Cộng Hoà của hôm nào nay đã mất tuôn chảy trong các sáng tác về refug-endity. Phóng bút Cũng Cần Có Nhau của Hoàng Xuân Sơn (2013) dắt tôi đi qua những cuộn phim chiếu chậm có bình luận về một giai đoạn lịch sử nhiều sóng gió (GlasseyTranguyen, 2013a). Quyển sách như một phim tài liệu kiểu Châu Âu - trong đó, người quay phim đi thụt lùi phía trước, đối diện với người trên màn ảnh, và bấm máy quay. Có lúc, tác giả lãng mạn, rừng rực sức sống thanh niên, bừng dậy những ước mơ, manh nha những hy vọng. Lắm lúc ông nhảy tưng tưng, lang bạt theo sức căng tràn tuổi trẻ, và ở đoạn này, cuốn phim chạy mau hơn bình thường. Có lúc ông chùn chân, chậm chạp đứng nhìn những hoang tàn, tan vỡ. Nhưng lúc nào cũng có hai Hoàng Xuân Sơn: một người trong cuộc, một người bên lề. Cũng Cần Có Nhau là một bức thư tình mà Hoàng Xuân Sơn gửi cho những người bạn đã từng cùng ông sống qua những chặng đường gần đây của đất nước và của thế hệ ông. Tự nhận là người 
Trangdai Glassey-Tranguyen- Biểu Đạt Căn Tính Di Dân trên Quê Huơng Việt-Mỹ và tại Hải Ngoại

bên-lề, nhưng tác phẩm của ông là một bản-lề, giữ cánh cửa hiện tại vào ngôi nhà quá khứ. Một giây phút thấm thía trong sách là lần một người bạn thân của tác giả, cố nhạc sĩ Trịnh Công Sơn, kéo ông đi hát 'Nối vòng tay lớn' trên đài truyền thanh của chế độ mới sau ngày 30 tháng Tư, 1975. Ống từ chối, và như những người bạn khác của Trịnh thời đó, thắc mắc không hiểu ông nhạc sĩ này đứng về bên nào. Cuối cùng, họ vẫn là bạn. Đây là một chọn lựa cá nhân, vì có nhiều người sau này coi Trịnh như một người phản bội và tay sai nằm vùng cho Cộng Sản tại Việt Nam Cộng Hoà. Phân chia ý thức hệ giữa tự do và gông cùm Cộng Sản vẫn còn mạnh mẽ trong cộng đồng Việt hải ngoại hôm nay.

Ký ức chiến tranh (Glassey-Tranguyen, 2008) tiếp tục lảng vảng trong căn tính di dân refug-endity - và không chỉ đối với thế hệ tỵ nạn mà thôi, mà còn đối với những thế hệ trẻ hơn, như tôi sẽ trình bày trong phần kế. Tháng Tư năm 2004, tôi soạn thảo và thực hiện một chương trình đa thể loại mang tên "Vết Thương Vô Diện, Hoà Bình Vô Danh," kết hợp tháng Di Sản Châu Á tại Đại học CSU Fullerton (được tổ chức vào tháng Tư thay vì tháng Năm như trên toàn quốc Hoa Kỳ, vì học sinh thi cuối khoá) và tưởng niệm Tháng Tư Đen tại Little Saigon, Quận Cam. Chương trình diễn ra tại Nhật báo Người Việt, Quận Cam, California, với sự góp mặt của văn nghệ sĩ từ nhiều lãnh vực và nhiều thế hệ, bao gồm phim, thơ, nghệ thuật tạo hình, ảnh phóng sự, và nhạc. Đạo diễn Howard Vũ ra mắt phim ngắn Running in Tall Grasses - Chay Trong Cỏ Cao trong chương trình này. Nhiếp ảnh gia Brian Đoàn triển lãm lần đầu tiên bộ ảnh "Những Người Bị Lãng Quên - The Forgotten Ones"—những hình ảnh ghi lại cảnh đời và cảnh ngộ của những người Việt vô quốc gia tại Phi Luật Tân, và đã được xuất bản thành sách năm sau đó. Cố nhạc sĩ Du Ca và nhà báo Nguyễn Đức Quang ${ }^{\text {xiv }}$ (Glassey-Tranguyen, 2012a) dẫn cử toạ với những bài hát thanh niên phổ biến từ thập niên 1960s, và có nội dung liên quan đến chủ đề của chương trình. Tôi đã viết lời tiếng Anh cho bài Hy Vọng Đã Vuơn Lên để mọi người cùng hát ở cuối chương trình. Đáp lại lời mời gọi của tôi và viết theo chủ đề "Vết Thương Vô Diện, Hoà Bình Vô Danh," nhà thơ Trần Mộng Tú ${ }^{\mathrm{xv}}$ viết bài thơ Chiến Tranh và Nhũng Đoá Hoa Vàng (Glassey-Tranguyen, 2004a) và diễn đọc bằng tiếng Việt ngày hôm đó, song song với phần diễn đọc tiếng Anh của tôi. Cô cũng đọc một bài thơ khác bằng tiếng Việt mang tên Quà Tặng Chiến Tranh. Đây là toàn bài thơ được viết theo chủ đề của chương trình:

Tôi có người yêu chết giữa chiến tranh

Tôi có người yêu chết cho hòa bình

Những mảnh đạn bom nổ tung da thịt

Những mảnh đạn bom nở giữa hoa vàng

Hôm nay tôi gọi người yêu thức dậy

Hôm nay tôi vỗ vào vai bình minh

Hôm nay nụ cười nở trên xác cũ

Nụ cười nở tung những đóa hoa vàng

Hôm nay tôi đứng trên thềm rất lạ

Vẫy tay gọi quá khứ về nhìn tôi

Hôm nay giọt lệ không còn mặn nữa

Giọt lệ nở tung những đóa hoa vàng

Hôm nay tôi đứng trên thềm rất lạ

Mặt trời sưởi ấm hai bàn tay tôi 
Trangdai Glassey-Tranguyen- Biểu Đạt Căn Tính Di Dân trên Quê Huoong Việt-Mỹ và tại Hải Ngoại

Bàn tay chạm lên vết thương vắng mặt

Vết thương nở tung những đóa hoa vàng

Hôm nay tôi đứng trên thềm rất lạ

Gọi một hòa bình không có đích danh

Tôi thả con chim bay vào trong gió

Trên môi nó ngậm một đóa hoa vàng.

Bài thơ ôm ấp cái tâm tình nhìn lại của một người phụ nữ đã sống qua chiến tranh và cố gắng đối diện với những vết thương vô diện và một nền hoà bình vô danh - cái hậu quả thật sự của cuộc chiến Việt Nam, tuy đã được chính thức kết thúc nhưng hệ quả của nó vẫn còn tiềm sinh hàng chục năm sau. Thể hiện chủ đề của chương trình, bài thơ nói về ước mơ hòa bình và thực tế của chấn thương hậu chiến - những vết đau không lành, những vết thương không thấy. Một cách để sống sót chiến tranh là tiếp tục hy vọng - và có thể vì lý do này mà Nhạc sĩ Nguyễn Đức Quang viết nên bài Hy Vọng Đã Vuơn Lên năm 1964, ngay giữa cao trào của cuộc chiến. Tôi mời mọi người cùng hát cộng đồng bài này để kết thúc chương trình "Vết Thương Vô Diện, Hoà Bình Vô Danh," sau khi cố nhạc sĩ trình bày hai bài Chuyện Quê Ta và Việt Nam Quê Hương Ngạo Nghế. Ca từ của bài hát như sau (Glassey-Tranguyen, 2004a):

Hy vọng đã vươn lên trong màn đêm bao ưu phiền

Hy vọng đã vươn lên trong lo sợ mùa chinh chiến

Hy vọng đã vươn lên trong nhục nhằn tràn nước mắt

Hy vọng đã vươn dậy như làn tên đang rực lên trong màn đêm

Hy vọng đã vươn lên trong nhà hoang trên ruộng cằn

Hy vọng đã vươn lên bên nương buồn dòng sông vắng

Hy vọng đã vươn lên trong lòng thuyền còn xa bến

Hy vọng đã vươn dậy như triều dâng cho buồm căng xuôi trường giang

Hy vọng đã vươn lên trên bàn tay trên mặt mày

Hy vọng đã vươn lên trong tim người không bối rối

Hy vọng đã vươn lên chân nhịp nhàng còn đi tới

Hy vọng đã vươn dậy trong lòng anh trong lòng tôi trong lòng ai

Hy vọng đã vươn lên trong mộ sâu quên ưu sầu

Hy vọng đã vươn lên dưới mặt trời thêm phơi phới

Hy vọng đã vươn lên trong cuộc tình toàn thế giới

Hy vọng đã vươn dậy trong ngày qua sang ngày nay cho ngày mai

\section{Kinh hoàng và Bất công tại Việt Nam sau chiến tranh}

Nhưng khi cuộc chiến Việt Nam kết thúc, hy vọng đã không sống sót. Trò hạ nhục nhân phẩm, nạn xâm phạm quyền con người, và cuộc truy sát mạng sống con người diễn ra khắp nơi tại

Việt Nam sau cuộc chiến ${ }^{x v i}$. Tôi cho rằng tiếng Việt đã bị làm nhục và sát hại sau 30 tháng Tư, 1975, khi chính quyền mới áp đặt cái ngôn ngữ của quân đội 'giải phóng' từ miền Bắc lên miền Nam. Dị bản "du kích” của tiếng mẹ đẻ được dùng để hãm hại chính người dân, như một cách 
Trangdai Glassey-Tranguyen- Biểu Đạt Căn Tính Di Dân trên Quê Huơng Việt-Mỹ và tại Hải Ngoại

trù dập, truy sát, và đàn áp. Do đó, những cố gắng vô bờ để giữ gìn tiếng Việt và phẩm giá của tiếng Việt từ 1975 tại hải ngoại có thể được coi như là một sự kháng cự đối với những hành động làm ô uế tiếng Việt của Hồng quân Bắc Việt, và là một sự cương quyết để giữ gìn cội rễ văn hoá của cộng đồng hải ngoại trên toàn cầu. Tôi đã lập luận trong các bài viết và bài phát biểu khác rằng ngôn ngữ chất chứa văn hoá, và việc duy trì ngôn ngữ đi song song với việc bảo tồn văn hoá. Đây là một khía cạnh liên quốc gia khác của căn tính refug-endity của người Việt, mà qua đó, cộng đồng người Việt hải ngoại thực thi tính tự lực tự phát trong tương quan với những biến cố diễ் ra trên quê hương.

Trong tác phẩm kinh điển Bụi và Rác (1992), cố nhà văn và cựu giảng sư tại Đại học UC Berkeley Nguyễn Xuân Hoàng (1940-2014), người chịu ảnh hưởng lớn bởi triết gia Pháp JeanPaul Sartre, ghi lại cái đảo điên trong tiếng Việt do đội quân miền Bắc đưa vào Nam và áp đặt lên miền Nam sau 1975. Sự ám sát ${ }^{x v i i}$ tiếng Việt đi đôi với đàn áp chính trị xã hội và khủng bố đối với người dân miền Nam, đưa đến những làn sóng di dân tiếp nối bằng mọi giá. Cái bất công đẫm máu này tiếp tục hạ thấp mọi người và mọi việc thành bụi và rác, như tác giả ghi lại ngay trong tựa sách. Tập truyện ngắn của Nguyễn, Căn Nhà Ngói Đỏ, góp nhặt những mảnh vụn của cuộc chiến Việt Nam, của lịch sử đô hộ tại Việt Nam, của sự mất mát nhân mạng trong chiến tranh và sự vô vọng, và của những câu hỏi cấp thiết về sự hiện hữu của con người. Ống thấy tình yêu là một xa xí phẩm trong thời chiến, và còn tệ hơn thế nữa dưới một chế độ độc tài toàn trị một thời gian dài sau khi bom đạn đã thôi rơi.

Hồi ký về chiến tranh và hậu chiến thuộc nhiều thể loại cũng nổi bật trong căn tính di dân refug-endity trên quê hương Việt-Mỹ VietnAmerica, với những kinh nghiệm chiến trường và trại cải tạo là hai chương sử đối lập trong đời sống của hàng trăm ngàn thanh niên miền Nam thời đó. Tác phẩm Phận Người, Vận Nuớc của Phan Nhật Nam (2013) là bản hùng ca dành cho những đồng đội của ông, cho người dân Việt Nam, cho một giai đoạn lịch sử tang thương của quê hương. Tự gọi mình là 'người lính viết văn,' Phan đứng ra làm một lễ giỗ bằng chữ nghĩa cho những người đã chết trong chiến tranh. Mỗi trang sách là một cái giô̂. Mỗi tựa đề là một lư hương. Mỗi câu chuyện là một linh vị, với cái tên của một miền đất Việt, với quân danh của một đồng đội đã ra đi, với tên gọi của một trận chiến. Những linh vị chít khăn tang. Phan Nhật Nam đi tìm những cái xác tinh thần của đồng đội để cho họ có một sự chôn cất tử tế. Đó là cái nghĩa của Phan Nhật Nam - của tình binh đệ. Phan chú trọng vào kinh nghiệm của người dân thuộc mọi thành phần xã hội, tương tự với việc tôi sử dụng những chứng từ lịch sử truyền khẩu để tạo nên một lịch sử chung với Dự án Việt Mỹ VAP từ thập niên 1990s (Tranguyen, 2004a), ghi nhận vai trò của mỗi người Việt trong dòng lịch sử chung của Việt tộc. Mỗi chúng ta là một gam màu trong bức tranh bi hùng đó. Những tác phẩm của Phan Nhật Nam là một hiệp ky, cùng giỗ những người lính đã nằm xuống, những người dân bỏ mình vì can qua. Chữ nghĩa của Phan Nhật Nam là bài truy điệu một quê hương đã mất mà không có mộ phần.

Nhưng những cuộc chiến kể từ khi có nền hoà bình hữu danh vô thực và sự thống nhất đất nước trên bề mặt năm 1975 còn khốc liệt hơn chiến tranh vũ trang - những chiến trường cho tự do khi con người bị tước đoạt hết tất cả mọi phương tiện để tự vệ. Hoả lò Cộng Sản, mà chế độ mới gọi cho êm tai là 'trại cải tạo,' là một đề tài chính yếu trong căn tính refug-endity của người Việt. Những trại lao động lấy mạng người này - mà tôi gọi là 'lò sát nhân và những cánh đồng chết' - nhắm vào việc phá huỷ sức lực của người tù cả về thể chất lẫn tinh thần. Những người tù là tinh hoa của miền Nam, những quân cán chính của Việt Nam Cộng Hoà, các văn nghệ sĩ, các chuyên gia mọi ngành, các vị lãnh đạo tôn giáo, vv. Có hàng trăm quyển sách và bài viết bằng tiếng Việt (và một số ít hơn bằng tiếng Anh) về đề tài này (chẳng hạn, Đỗ Văn Phúc, 2008), được viết bởi cả những tác giả thành danh và các tác giả khác, nhưng đa số là nam vì 
Trangdai Glassey-Tranguyen- Biểu Đạt Căn Tính Di Dân trên Quê Huoong Việt-Mỹ và tại Hải Ngoại

chênh lệch tỉ lệ nam nữ trong Quân đội miền Nam và trong các chuyên ngành bị coi là có nguy hiểm đối với chế độ mới. Một số nhỏ các tác phẩm, như quyển Đoá Hồng Gai (2007) của cựu tù nhân Nguyễn Thanh Nga, đưa ra một cái nhìn của người phụ nữ đã chịu đựng và sống sót những quần đảo ngục tù ở Việt Nam. Tác phẩm Thung Lũng Tư Thần của cố nhà báo Vũ Ánh được Nhật báo Người Việt xuất bản thành những bài viết hằng tuần, và được in thành sách sau khi ông qua đời vào tháng Bảy, 2014. Trong phần nói chuyện của mình (Glassey-Tranguyen, 2014b) tại buổi ra mắt sách, tôi nhận định rằng nhà báo Vũ Ánh, giống như những tác giả khác viết về trại tù cải tạo, đã không coi quyển sách của mình có tính lịch sử hay văn chương. Ông nói ông chỉ đơn giản ghi lại những giây phút còn đọng lại trong trí nhớ hai mươi lăm năm sau khi ra tù, và bởi vì những giây phút này vẫn kiên trì ở lại trong trí nhớ mặc cho thời gian qua đi, có nhiều khả năng là chúng phản ánh thực tế và đáng tin ${ }^{\text {xviii }}$. Có những bạn tù đã từng sống với tác giả ở nhiều trại cải tạo - như bạn tù và nhà văn được nhiều người kính trọng, Phạm Xuân Đài - đã đến dự buổi ra mắt sách và chứng thực giá trị chính xác trong những bài báo và trong quyển sách của nhà báo Vũ Ánh.

Trong phần mở đầu, tác giả Vũ Ánh nói rằng ông không nhằm viết một tác phẩm văn chương hay lịch sử, nhưng chỉ kể lại kinh nghiệm của mình cho con cháu mình và con cháu của bạn tù được biết. Tôi cho rằng vì chính lý do này mà quyển sách có một giá trị chính xác cao trong việc kể lại kinh nghiệm và cái nhìn của con người ở giữa những bức tường của trại cải tạo. Từ cái nhìn của một nhà lịch sử truyền khẩu, tôi có thể nhấn mạnh rằng Thung Lũng Tử Thần là một tác phẩm lịch sử giá trị, phản ánh trung thực kinh nghiệm con người và soi rọi một giai đoạn lịch sử quan trọng của Việt Nam. Qua hai mươi lăm năm suy niệm và nhìn lại, Vũ Ánh đã để cho tất cả những khốn đốn và bất công của trại cải tạo lắng đọng trong tâm trí ông, để ông viết như một con người đã hoá kiếp, đi từ kiếp tù đày của trại cải tạo, đến đời tự do của một nhà báo tại miền đất tự do Hoa Kỳ. Cái tâm bình an của ông đã giúp chúng ta nhìn thấy "Thung Lũng Tử Thần" một cách rõ ràng, với cái Tâm Một.

Trong lời mở đầu của Đại Học Máu, một tác phẩm khác về hoả lò Cộng Sản mang tên 'trại tập trung,' tác giả Hà Thúc Sinh viết ${ }^{x i x}$,

Quyển sách này không thể là một tác phẩm tiểu thuyết văn chương, cũng không thể nằm trong hình thức một hồi ký chính trị hoặc một bút ký lao tù. Quyển sách này, thực tế, chỉ có thể được coi như một đống quặng mỏ, được khai quật và còn giữ nguyên hình thái chân thực của nó. Hoặc có thể nói một cách khác, bảy mươi chương sách này có thể xem như bảy mươi tấm ảnh, được chụp liên tục và được rửa ra bởi một phó nháy may mắn và có tính tiếc của, nháy được bảy mươi hoàn cảnh buồn nhưng có ý nghĩa trong đời tù cải tạo dưới chế độ cộng sản. Hoặc có thể nói một cách khác hơn nữa, quyển sách này là bản phúc trình của một người lính VNCH bị bỏ rơi, bị ở tù cộng sản, rồi thoát được ra ngoài, ngồi viết lại để kính gửi tới những ai còn thương yêu và còn quan tâm đến nước Việt Nam và con người Việt Nam còn ở lại...

Tuy Hà và những tác giả của những tác phẩm tương tự đều cho rằng mình không viết theo một thể loại nào và tác phẩm của mình không có giá trị văn chương, nhưng những sáng tác này có một sự phong phú về từ ngữ, văn phong điêu luyện, và sử dụng nghệ thuật trào phúng cách tuyệt vời trong những đề tài tăm tối như là trại cải tạo tại Việt Nam. 
Trangdai Glassey-Tranguyen- Biểu Đạt Căn Tính Di Dân trên Quê Huoong Việt-Mỹ và tại Hải Ngoại

\section{Phong trào Thuyền Nhân: Nối Dài và Khoảng Lặng}

Một đề tài tang thương khác nổi bật trong căn tính refug-endity của người Việt là kinh nghiệm thuyền nhân. Có nhiều tác giả viết về đề tài này, và có nhiều văn khố thuyền nhân được thiết lập ${ }^{\mathrm{xx}}$, các đài tưởng niệm được xây ${ }^{\mathrm{xxi}}$, và những cuộc hành trình "Về Bến Tự Do" của người Việt hải ngoại về thăm lại những trại tỵ nạn cũ nơi mà Cao Uỷ Tỵ Nạn Liên Hiệp Quốc giải quyết hồ sơ của thuyền nhân đi định cư ở các nước thứ ba. Vì tôi sẽ nói thêm về đề tài này ở phần sau, tôi xin nhấn mạnh ở đây rằng tuy có nhiều tài liệu văn khố và sinh hoạt liên quan đến kinh nghiệm thuyền nhân, nhưng vẫn còn một khoảng lặng: kinh nghiệm của thuyền nhân từ Bắc Việt Nam. Nhóm thuyền nhân này ít được biết đến và có nhiều người đã định cư tại các nơi trên thế giới, đặc biệt là Thuỵ Điển, với đa số là người Việt gốc Hoa (Glassey-Tranguyen, 2015). Khi nói đến cộng đồng người Việt hải ngoại, người ta thường chú trọng đến người tỵ nạn và di dân ra đi từ miền Nam sau 1975. Tuy nhiên, có một số lớn người miền Bắc xuất ngoại qua nhiều cách: những người đi theo diện xuất khẩu lao động đến các nước xã hội chủ nghĩa, thương nhân, du sinh, các nhà ngoại giao, và thuyền nhân. Đối với thuyền nhân đi từ miền Bắc, cơ hội định cư rất mong manh vì họ ra đi trong những đợt cuối cùng. Đuờng Phía Bắc (2012) của Lê Đại Lãng, một tác giả hiện sống tại Việt Nam, là một tài liệu quý hiếm về những câu chuyện của nhiều 'nạn nhân' (chữ mà Lê Đại Lãng dùng để chỉ thuyền nhân từ miền Bắc) đã đến được nước thứ ba, hoặc bỏ mạng trên đường. Họ đối diện với những nguy hiểm của biển cả hãi hùng, những tiến thoái lưỡng nan đầy gian trá trên đất liền, và bị từ chối định cư ở các trại tỵ nạn sau khi Cao Ủy Ty. Nạn Liên Hiệp Quốc áp dụng những quy chế thanh lọc gắt gao và bất công khi xét đơn cho thuyền nhân đi định cư. Tôi cho rằng (Glassey-Tranguyen, 2012b) Đương Phía Bắc là một chương sử câm nín của thuyền nhân đi từ miền Bắc, vì kinh nghiệm và câu chuyện của họ vần còn bị phong kín và không được biết đến trong lịch sử Việt Nam hải ngoại.

\section{Giữ gìn và Thấu hiểuxxii Di sản Văn hoá Việt Nam}

Bên cạnh những biểu đạt về kinh nghiệm đương đại, một yếu tố quan trọng trong văn chương nghệ thuật Việt hải ngoại là những kho báu về văn hoá Việt Nam được trao lại từ ngàn đời và những thấu hiểu hiện nay về những kho báu đó. Những bảo vật văn hoá mà người Việt hải ngoại nổ lực gìn giữ vốn rất đa dạng: ngôn ngữ, âm nhạc, nghệ thuật, triết học, thuần phong mỹ tục, vv. Một ví dụ điển hình là trở về quá khứ để thỉnh về những hạt ngọc quý ít được thế hệ trẻ hôm nay biết đến và chia sẻ với họ. Nguyên Giác Phan Tấn Hải, Chủ bút Nhật báo Việt Báo, thu thập, chú giải, và chuyển qua Anh ngữ một bộ sách ba tập các bài thơ thiền của những vị thiền sư Việt Nam (Glassey-Tranguyen, 2011b). Bộ sách nối nhịp cầu cần thiết cho những độc giả lần đầu đọc các dòng thơ cổ uyên bác này, và góp phần vào sự ưa chuộng các phương pháp tu Thiền ngày càng phổ biến ở phương Tây gần đây. Bộ sách là kho tàng quý báu với những áng thơ Thiền mẫu mực của Việt Nam, triết lý Thiền, và tư duy văn hoá Việt. Những người yêu thơ sẽ cảm kích cách diễn đạt tài tình, cách dùng từ chọn lọc, và những nhịp điệu biến thể. Những ai trân quý văn hoá Việt Nam sẽ gặp gỡ những hình ảnh, cảm xúc, và suy tư quen thuộc.

Cộng đồng hải ngoại cũng duy trì một phong trào mạnh mẽ và bền bỉ để bảo tồn và phát huy âm nhạc Việt Nam 'truyền thống'xxiii . Những sinh hoạt này dần dà trở thành một phần trong chương trình học tại các trường học công lập và đại học. Tiến sĩ Nguyễn Thuyết Phong, tốt nghiệp từ Đại học Sorbonne và sáng lập viên của IVM Institute of Vietnamese Music xxiv, và là một Nhạc sĩ Di Sản Quốc Gia của Hoa Kỳ, đã đi khắp nước Mỹ để ghi âm lời hát và tiếng đàn trong các gia đình Việt Nam. Trong quyển Searching for a Niche (1995), Nguyễn kể lại việc ông 
Trangdai Glassey-Tranguyen- Biểu Đạt Căn Tính Di Dân trên Quê Huơng Việt-Mỹ và tại Hải Ngoại

trở thành một trong những người giữ gìn nhạc Việt tại hải ngoại (tác giả chuyển ngữ),

...Tại Nhật và Châu Âu, tôi đã tham gia vào những chương trình nhạc Việt truyền thống từ năm 1973. Tôi đi cùng với những đoàn trình diễn từ Paris đến Amsterdam, từ Lyons đến Bern và Stuggart và cảm nhận tất cả sức sống của nó. Nhưng mãi đến khi tôi đến Mỹ thì tôi mới bắt đầu chú trọng đến âm nhạc Việt như một đề tài nghiên cứu. The National Endowment for the Arts and the Social Science Research Council đã giao cho tôi công việc đi tìm, nhận định, và đánh giá âm nhạc trong cộng đồng người Việt di dân tại Mỹ. Công việc này cho phép tôi gặp gỡ nghệ sĩ tại nhiều tiểu bang và thấy được âm nhạc của họ trong cuộc sống và cuộc sống trong âm nhạc... Tuy nhiên, chuyến đi cho thấy những nghệ sĩ âm nhạc trong cộng đồng người Việt có một cái nhìn chung: tiếp tục bằng mọi giá, cảm thấy nhu cầu để diễn đạt chính mình qua âm nhạc (tr. 5-6).

(Nguyên văn Anh ngữ: “...In Japan and Europe I had been engaged in performances of traditional Vietnamese music since 1973. I traveled with theatrical troupes from Paris to Amsterdam, from Lyons to Bern and Stuttgart and sensed all of its vigor. But it was in the United States that I began dealing with Vietnamese music as a real topic of interest. The National Endowment for the Arts and the Social Science Research Council commissioned me with the task of searching for, assessing, and evaluating music in the Vietnamese immigrant communities across the United States. This provided me an opportunity to meet with artists in several states and see their music in real life and real life in music... My adventure in this domain revealed, however, that music makers in the Vietnamese communities had one shared view: to continue regardless of whatever happened to them, feeling the need to express themselves through their music (pp. 5-6).

Khi nói đến sự hiện diện văn hoá, tiếng nói và phong tục của những sắc dân thiểu số từ Việt Nam xứng đáng được quan tâm hơn là trong tình trạng hiện nay, cả tại Việt Nam và tại hải ngoại. Cần phải công nhận và đưa những tiếng nói này vào di sản văn hoá Việt Nam cả trong và ngoài Việt Nam, đặc biệt đối với những nhóm sắc tộc đã bị sát hại và đẩy ra lề xã hội. Vì lý do đó, tôi dành phần còn lại của đoạn này để nói về một nghệ sĩ người Chăm và tác phẩm của cô. Tại cuộc triển lãm mùa xuân 2002 do VAALA tổ chức (Glassey-Tranguyen, 2012c) với chủ đề "Đời sống tuần hoàn-Cycles of Life," nghệ sĩ và tác giả trứ danh Julie Thị Underhill ${ }^{\mathrm{xxv}}$ cống hiến hai bức ảnh của Bà Ngoại cô: Cải Táng, và Ôm. "Ôm” được chụp tại Phước Lập, Việt Nam, với người em họ của Underhill đang ôm Bà Ngoại người Chăm của cô đang hấp hối trên giường. "Cải Táng” được chụp trong lần chôn cất thứ hai của bà, khi một pháp sư Bà La Môn đang thực hiện nghi thức sau cùng trong sự chứng kiến của gia đình. Là một tiếng nói nổi bật cho những vấn nạn của người Chăm trên toàn thế giới, Underhill đã tranh đấu cho quyền của người sắc tộc Chăm và nữ quyền, cũng như những vấn đề khác. Về các hình triển lãm, cô giải thích (tác giả chuyển ngữ),

Tôi có một tấm hình đôi của Bà Ngoại người Chăm của tôi trong cuộc triển lãm này. Bà sống trong một làng nhỏ ở ngoại ô Phan Rang, Việt Nam. Đề tài Đời Sống Tuần Hoàn rất thích hợp cho loạt hình này, bởi vì tấm hình thứ nhất là hình Bà Ngoại tôi đang lâm chung và tấm hình thứ hai là hình mộ thật của bà, trong ngày cải táng bà. Một số nhỏ người Chăm Bà La Môn, hay Chăm theo Ân Giáo, vẫn giữ phong tục này. Nhưng rất ít người Mỹ gốc Việt biết đến nghi thức này và những nét văn hóa khác của dân tộc Chăm. Do đó, tôi rất cảm kích có cơ hội triển lãm phần chân dung gia đình này. 
Trangdai Glassey-Tranguyen- Biểu Đạt Căn Tính Di Dân trên Quê Huơng Việt-Mỹ và tại Hải Ngoại

(Nguyên văn Anh ngữ: "I have a black-and-white photography diptych of my maternal Cham grandmother in this exhibit, who lived in a small village outside of Phan Rang, Viet Nam. The theme Cycles of Life suits this work well, because the first photo shows my grandmother on her deathbed and the second photo shows her actual gravesite, the day of her second burial. A very small percentage of Cham Balamon, or Hindu Cham, still practice second burials. Yet the Vietnamese American community generally knows very little about our ceremonies and other aspects of Cham culture, so I appreciate the opportunity to exhibit this family portraiture.")

Thật thú vị, trong thời gian tôi nhận học bổng Fulbright 2004-2005, tôi đã có nhiều cuộc trao đổi về phong tục cải táng với người Việt đến từ Hải Phòng đang sống tại Thuỵ Điển và đến từ Hà Nội đang sống tại Berlin. Như Underhill nhắc đến, rất ít người Mỹ gốc Việt biết đến phong tục này. (Thiết nghĩ có lẽ là vì thành phần dân số của VietnAmerica, phần lớn đến từ miền Nam sau 1975, tuy có nhiều người đã di cư từ miền Bắc năm 1954). Do đó, người nữ hoạ sĩ này đã có một ý thức và quyết tâm gìn giữ và tranh đấu quyết liệt cho sự hiện diện của cộng đồng sắc tộc Chăm của mình. Underhill nói thêm (tác giả chuyển ngữ):

Sau chuyến thăm Việt Nam đầu tiên, Bà Ngoại tôi qua đời, và trong hai ngày người nhà không thể tìm được một pháp sư để lo hậu sự cho bà. Khi xác của Thi Oui bắt đầu tan, gia đình chúng tôi không có tiền để mua nước đá để ủ bà. Vì không có pháp sư, bà không được chôn cất theo đúng nghi thức. Sáu năm sau, Thi Oui vẫn nằm trong một cái mộ không được ghi dấu, chờ đợi được cải táng đến nghĩa trang Ấn Giáo tại Phước Lập, Việt Nam. Là một nghi thức của người bản xứ gốc, chôn cất lần thứ hai ghi nhận sự đồng-tồntại của người sống và người chết, và thừa nhận mối tương quan giữa cơ thể, linh hồn, tang gia và xã hội. Trong thời gian chiến tranh, trên khắp Việt Nam, những gia đình bị lấy đất cũng đào mộ của tổ tiên lên để cải táng. Nghi thức này trở nên cần thiết cho Bà Ngoại tôi, vì bà đã không được chôn cất tử tế lần đầu. Trong lần chôn cất thứ hai, chúng tôi hốt cốt bà, rửa xương, và dời bà đến đất thánh, trong lúc dòng họ và bạn bè cầu nguyện trong suốt ba ngày, cùng ăn uống, và dâng cúng cho bà và những tổ tiên khác. Không như người Chăm Hồi Giáo ở Việt Nam và Cambốt, vốn giữ rất ít truyền thống mẫu hệ, người Đông Chăm theo Ấn Giáo là một trong số ít các xã hội trên thế giới vẫn theo mẫu hệ và sống gần gia đình họ mẹ, được thừa hưởng tài sản, được kế vị trong chính trị, và nhà ở được truyền từ mẹ đến con gái. Trong một văn hoá vốn tôn kính tổ tiên, sùng bái thánh mẫu, và đặt phụ nữ làm gia trưởng, việc chôn cất lần hai của một bà tổ mang ý nghĩa quan trọng cho gia đình và cộng đồng.

(Nguyên văn Anh ngữ: "Following my first visit to Viet Nam, my grandmother died, and for two days the holy man could not be found to administer rites. When Thi Oui began to decompose, our family could not afford to pack her in ice. In the absence of the holy man, she was buried without proper sacrament. Six years later, Thi Oui remains in an unmarked grave, awaiting a second burial in the Hindu cemetery in Phước Lập, Việt Nam. An indigenous practice, reburial recognizes the coexistence of the dead and the living, and assumes the interrelationship of the body, soul, bereaved and society. During war, throughout Viet Nam, families forced from their lands also exhumed their ancestors for reburial. The ceremony became necessary for my grandmother, due to her dishonorable first burial. During her second burial, we unearthed Thi Oui's body, cleaned her bones, and moved her to the sacred grounds, as family and friends prayed for three 
Trangdai Glassey-Tranguyen- Biểu Đạt Căn Tính Di Dân trên Quê Huoong Việt-Mỹ và tại Hải Ngoại

days, feasting and leaving offerings for her and other ancestors. Unlike the Muslim Cham of both Viet Nam and Cambodia, who retain very little of their woman-centered ancestry, the Hindu Eastern Cham remains one of the world's rare matrilineal and matrilocal societies, with property inheritance, political succession and residence passed from mother to daughter. In a culture that venerates ancestors, celebrates mother goddesses, and places women at the head of the house, the reburial of a matriarch holds much significance for the family and the community.")

\section{BIỂU HIỆN TOÀN CẦU}

Việc thể hiện tính tự lực tự phát của thế hệ tỵ nạn có thể được dòng chính thấy rõ hơn khi nói đến phát triển kinh tế và tham gia chính trị, nhưng không hẳn như vậy trong lãnh vực văn học nghệ thuật. Có thể bởi vì rào cản ngôn ngữ và khoảng cách văn hoá giữa VietnAmerica và dòng chính, hoặc giữa cộng đồng Việt hải ngoại ở nơi khác và văn hoá chủ lưu ở đất nước đó. Nhưng dù không được người ngoài cộng đồng biết đến, tính tự lực tự phát này mạnh mẽ ấp ủ những mùa nghệ thuật mới từ bên trong. Tôi cho rằng qua sự tự lực tự phát của mình, những thế hệ người Việt tỵ nạn đã giúp nuôi dưỡng động lực sáng tạo trong những thế hệ sau. Bởi vì, cảm nhận và thực hành sự tự lực tự phát của thế hệ tỵ nạn tạo ra điều kiện thích hợp cho những thế hệ sau tìm được hướng đi cho sáng tạo của mình. Nói một cách khác, khi thế hệ thứ nhất tận hoạt tính tự lập tự phát ở nước tạm dung, họ thúc đẩy những thế hệ sau tìm về quá khứ và đi vào di sản - trong khi cả hai thế hệ cùng thương lượng với khoảng cách thế hệ, rào cản ngôn ngữ, và khác biệt văn hoá. Thế hệ 1.5 và những thế hệ ngoại biên có thể làm chủ những dấn thân sáng tạo của mình. Nhưng nguồn tài liệu dồi dào cùng với môi trường thảo luận và những biểu hiện không giới hạn về căn tính refug-endity của người Việt trong cộng đồng - và ở mức độ thấp hơn trong các văn khố dòng chính - chỉ có thể làm giàu cho sáng tác và cái nhìn của những thế hệ mới.

\section{Sự nối tiếp liên-thế-hệ của Refug-endity}

Tôi muốn nhấn mạnh rằng kinh nghiệm sống và quá trình khai mở tâm thức trong gia đình - hay tại quê nhà, đối với thế hệ 1.5 - là những tài sản cốt yếu cho các văn nghệ sĩ ngoại biên nào chọn khai thác những đề tài liên quan đến căn tính di dân. Những miền ký ức, hồi ức lịch sử, và việc ôn lại trãi dài trên các không gian cá nhân, không gian thế hệ, không gian quốc gia, không gian liên quốc gia, và không gian lịch sử. Những miền không gian này lồi lõm, đứt đoạn, không liền lạc, và trơn trợt, như tôi đã bàn đến ở phần đầu của bài này. Nhưng như những văn nghệ sĩ thế hệ ngoại biên đã cho thấy, những không gian này có thể hữu dụng và thúc đẩy sáng tạo trong việc nhận ra cái cá thể và cái chính thể, mở ra những hiểu biết mới và vận hội mới. Trên những không gian này, sự nối tiếp của căn tính di dân sắc tộc refug-endity được hiển lộng hoàn toàn.

Có thể thấy được một mối nối mạnh mẽ và quen thuộc trong tác phẩm của những thế hệ Việt trẻ ngoại biên, mặc dù chính cha mẹ của họ có thể không phải là văn nghệ sĩ. Qua sáng tác của mình, những văn nghệ sĩ mang cái gia đình, cái cá thể, và quá khứ vào trong bối cảnh toàn cầu cho cả thế giới ngắm nhìn - quá khứ của chính gia đình họ, của Việt Nam, và của cộng đồng sắc tộc. Thật không thể nào bàn đến tất cả những văn nghệ sĩ ngoại biên trong bài viết này, cũng như trong trường hợp của thế hệ tỵ nạn. Do đó, tôi chọ̣ những văn nghệ sĩ nào chú trọng vào các chủ đề tôi cho rằng có liên quan đến refug-endity để phân tích trong phần này ${ }^{\text {xxvi }}$. Tôi cũng có vinh hạnh cộng tác và/hoặc phỏng vấn hầu hết các vị này, và do đó tôi có những tài liệu gốc chưa 
Trangdai Glassey-Tranguyen- Biểu Đạt Căn Tính Di Dân trên Quê Huoong Việt-Mỹ và tại Hải Ngoại

bao giờ xuất bản về kinh nghiệm tỵ nạn và tác phẩm của họ. Một số tài liệu gốc được trích dẫn trong đoạn này trước đây chỉ được xuất bản bằng tiếng Việt và tôi đã chuyển ngữ để đưa vào bản tiếng Anh của bài này, hoặc từ văn khố riêng của tôi với các tài liệu từ những dự án nghiên cứu tôi đã thực hiện trong cộng đồng Việt Nam hải ngoại trong hai thập niên qua.

Tôi cho rằng có một sự tiếp nối của căn tính di dân trong thế hệ trẻ hơn, dù họ có lớn lên trong một gia đình văn nghệ sĩ hay không. Những văn nghệ sĩ dựa trên kinh nghiệm tỵ nạn của gia đình và bản thân, tái tạo và tái thể hiện những kinh nghiệm này qua phim ảnh, thơ, và nghệ thuật tạo hình. Vì vậy, trước hết, chúng ta cần phải hiểu kinh nghiệm tỵ nạn của họ, và làm sao ký ức về những kinh nghiệm này lại hiện về, làm giàu cho nội dung hoặc biến đổi sáng tác của họ. Đối với một số văn nghệ sĩ được bàn đến, xu hướng tính dục và những giằng co về mặt này là một khía cạnh quan trọng trong đời sống và tác phẩm của họ, cũng như trong quan hệ của họ với gia đình. Thái độ của thế hệ thứ nhất về đồng tính luyến ái khá đa dạng và phức tạp, từ thái độ khước từ thẳng thắng đến cởi mở đón nhận. Một số cha mẹ có thái độ khước từ đối với con cái đồng tính có thể vì họ cảm thấy thất vọng đối với giới tính của con cái, và họ nổi giận vì đối với họ, sau tất cả những khó khăn mà cả gia đình đã trãi qua, con cái lại làm xấu mặt mình như vậy. Những cha mẹ nào chấp nhận giới tính của con mình có thể vì họ đã từng đứng trên bờ sinh tử nhiều lần. Những giằng co về giới thính này ảnh hưởng cả văn nghệ sĩ lẫn tác phẩm của họ, hoặc là cho họ sự hỗ trợ tinh thần để đưa sáng tác của họ đi tới, hoặc là kích thích họ với cảm giác bị hất hủi trong gia đình và làm cho nghệ thuật của họ trở nên mạnh mẽ.

Một ví dụ rõ ràng về mối tương quan giữa kinh nghiệm tỵ nạn của thế hệ trẻ và nghệ thuật của họ là tác phẩm của Đạo diễn Khoa Đỗ (Glassey-Tranguyen \& Đỗ, 2009), với những bộ phim xoay quanh chuyện vượt biển (Đỗ, 2010) và đời sống ở Ưc Châu (Đỗ, 2001; 2006). Nhiều gia đình Việt Nam tỵ nạn thường tránh động đến hay những thương tâm của quá khứ, nhưng gia đình của Đỗ bắt đầu nói về những chuyến vượt biên như một cách để tạo tình thân - và tôi cho rằng, cũng để nguôi ngoai. Sinh ra tại Sài Gòn tháng Giêng năm 1979, Đỗ lớn lên trong môi trường văn hoá Việt Nam giữa cộng đồng tỵ nạn ở New South Wales, Úc Châu; nhưng môi trường quan trọng hơn cả, là quanh bàn cơm (Glassey-Tranguyen, 2014a), nơi gia đình anh kể lại những câu chuyện về chuyến vượt biển năm 1980 mà anh không nhớ nhiều. Tôi gọi quá trình này là "tái thiết quá khứ quanh bàn cơm." Đỗ nhớ lại (Glassey-Tranguyen, 2014c) (tác giả chuyển ngữ):

Chiếc ghe chỉ dài có 9 mét, và có 40 người trong chuyến đó. Đi năm ngày thì được vớt và đưa qua Mã Lai, trại Pulau Bidong. Đây là một trong những câu chuyện thường được nhắc đi nhắc lại khi gia đình Khoa gặp nhau ăn tối, và trò chuyện. Đến cuối bữa ăn, thì luôn luôn những câu chuyện này cứ tiếp tục tuôn ra. "Nhớ hôn, lần đó mình đi trên ghe, mà bị chết máy. Rồi mình mất một cái chân vịt, và Cậu Sáu phải nhảy xuống để thay. May mà tôi mang theo một cái chân vịt nữa, thấy hôn! Mẹ nói tôi đừng có mang thêm chân vịt, nhưng tôi cứ mang, nếu không thì bây giờ hổng chừng mình vẫn còn trôi dạt lênh đênh đó." Tất cả những câu chuyện này cứ tuôn ra. "Nhớ hôn, lần đó mình bị hải tặc tấn công, tưởng đâu là nó thảy Khoa xuống biển rồi, may mà nó không thảy." Và đủ thứ chuyện... Khoa nghĩ, từ những câu chuyện này mà mình tái thiết lại lịch sử.

(Nguyên văn Anh ngữ: "We had a boat that was about nine meters long. There were about forty people on the boat. We traveled for about five days before we got picked up and taken to Malaysia, to Pulau Bidong refugee camp... It's one of those stories that so often talked about when the family meets for dinner. And towards the end of dinner- 
Trangdai Glassey-Tranguyen- Biểu Đạt Căn Tính Di Dân trên Quê Huoong Việt-Mỹ và tại Hải Ngoại

always - these stories would keep coming out. 'Remember that time we were on the boat, and the engine broke down. And we lost a propeller, and Uncle Sáu had to jump down and change the propeller. Lucky I brought the extra propeller, see! Mum told me not to bring the propeller, but I brought the propeller, otherwise we would still be drifting now.' All these stories came out, you know. 'Remember that time when the pirates attacked us, we thought they were going to throw Khoa overboard, but luckily they didn't.' And all sorts of stories, and I guess it is from these stories that you construct your history...”)

\section{Dựng lại ký ức đang trượt đi xa}

Cần phải có nhiều can đảm để vượt qua biển đen - cả trong kinh nghiệm đời thật như vượt biển, và trong tiềm thức khi ta tìm về quá khứ - để được nguôi ngoai và bình tâm. Đỗ cho chúng ta một cách nhìn khác về quá khứ: bằng cách đan xen nó với hiện tại. Trong phim feature Cá $M e ̣$ Mother Fish (2010, phim tiếng Việt, phụ đề Anh ngữ), Đỗ đã chồng chất chuyến vượt biên lên một tiệm may ở Úc Châu, cho thấy quá khứ tiếp tục hiện diện vượt thời gian và không gian (Glassey-Tranguyen, 2011c). Nhưng, ký ức vốn không chắc chắn, ngay cả khi ta hồi tưởng và tái thiết nó một cách có ý thức. Đỗ không biết mình nên làm gì với những hình ảnh của quá khứ (tác giả chuyển ngữ): "Và kết quả là từ những câu chuyện này, Khoa tưởng tượng ra được chiếc ghe. Thú thật với Trangđài, Khoa không biết đây là những hình ảnh thật, hay chỉ là những tái thiết từ những câu chuyện Khoa được nghe" (nguyên văn Anh ngữ: And as a result of these stories, I have images of the boat. To be honest with you, I don't know whether they are real images, or whether they are constructions of the stories that I've heard.) Nhưng anh nhận ra tầm quan trọng của những ký ức này, và nhu cầu giữ gìn chúng cho mai hậu (tác giả chuyển ngữ):

Khoa nghĩ điều quan trọng là những câu chuyện này được kể lại, được truyền lại, bởi vì chúng ta cần giữ lại lịch sử của mình và ghi nhận lịch sử đó cho thế hệ mai sau. Khoa sẽ kể lại những câu chuyện này cho con cái nghe. Những câu chuyện này giúp chúng ta định nghĩa mình là ai. Chính những câu chuyện này là thiết kế của cả một lịch sử. Khoa rất vinh dự, và cũng rất may mắn, được $\mathrm{Ba} M e ̣$ và gia đình kể cho nghe những câu chuyện này.

(Nguyên văn Anh ngữ: "I think it's important that these stories are told, it's important that these stories are passed on. Because I think it's so important to keep our history and we record it for the next generation and the next generation. I'll pass these stories to my children. These stories make us who we are. They are a construct of a whole history. I'm privileged, and I guess fortunate, that my parents did share these stories, that my family does share those stories.")

Những câu chuyện quanh bàn cơm như thế này giúp người Việt tỵ nạn tìm được bình an sau bao sóng gió. Chính quá trình chữa lành giúp cho nụ cười hài hước được thắp lên trong đời sống của người Việt tỵ nạn, như trong phim 2006 Tình Nhu Thủ Túc (tôi dịch từ tựa phim tiếng Anh Footy Legend) - phim đầu tay của Đỗ và được nhiều giải thưởng. Truyện phim diễn ra tại khu ngoại ô phía Tây của Sydney và nói về Lực Vũ, một thanh niên Úc gốc Việt có niềm đam mê bóng đá. Lực đang thất nghiệp và đối diện với nguy cơ không được chăm sóc cho Anne, em gái mình nữa, vì bị coi là không có khả năng làm một người giám hộ có trách nhiệm thay cho cha 
Trangdai Glassey-Tranguyen- Biểu Đạt Căn Tính Di Dân trên Quê Huơng Việt-Mỹ và tại Hải Ngoại

mẹ anh đã qua đời. Lực tụ họp các bạn cũ từ đội banh ở Trường Trung Học Yagoona - những người cũng đối diện với những vấn đề xã hội như thất nghiệp dài hạn, nghiện ngập, những hậu quả của việc có con ở tuổi teen. Đội thắng giải Holden Ute và được hợp đồng quảng cáo cho hãng Lowes Menswear. Khởi đi từ kinh nghiệm tỵ nạn, lớn lên trong một khu dân cư nghèn nàn tại Sydney với bạn bè thuộc nhiều sắc tộc, Đỗ chọn chú trọng vào cái chung để nói đến những khác biệt chủng tộc và hướng tới hòa hợp, cùng tồn tại, và bản năng sinh tồn cộng thể. Khi tôi nhận xét rằng nhân vật chính trong phim là một người Việt, nhưng phim không chú trọng về sắc tộc, Đỗ tán thành. Đó là bởi vì đối với anh (tác giả chuyển ngữ),

...đôi khi chú trọng vào sắc tộc lại không nhất thiết chữa lành hay giải quyết vấn đề một cách hữu hiệu. Bởi vì khi đặt nặng một vấn đề thì có thể vô tình đưa nó đi sai hướng. Thay vì tập trung vào sắc tộc như một vấn nạn, chúng tôi nghĩ, "Hãy chú trọng vào những cái chung." Thay vì chú trọng vào những điều dị biệt, hay chủng tộc, chúng tôi chú trọng vào những điểm tương đồng, vào những gì mọi người cùng san sẻ với nhau. Điểm chung của các nhân vật trong phim là niềm đam mê thể thao, túc cầu, và thích vui chơi nô đùa với nhau. Khoa nghĩ trong suốt bộ phim, khi chúng tôi làm nổi bật những điểm chung, và tuổi thơ, ký ức, thì chúng tôi đối diện với những vấn đề chủng tộc hay giai cấp, nhưng ở mức độ tiềm thức, thay vì bổ búa vào đầu người xem. Lớn lên với bạn bè thuộc nhiều sắc tộc, chúng tôi không nhất thiết quây quần và thảo luận, "À, kinh nghiệm làm người Lebanon thì như thế nào? Hay người thổ dân Úc sống ra sao?" Chúng tôi không bao giờ nói về những điều này. Nên Khoa nghĩ, "Thôi thì hãy tránh những câu chuyện này trong phim và đi vào những điểm chung."

(Nguyên văn Anh ngữ: “...sometimes, to focus on race may not necessarily heal, may not necessarily tackle the issue successfully. Because to highlight the issues, to highlight the problems, may serve to reinforce the wrong discussion. Instead of focusing on race as an issue, we thought, 'Let's focus on what they have in common.' Rather than focusing on differences, which is race, we focus on similarities, on what they have in common, on what they have together. What they have in common is their love of sports, of football, of playing together and being together. I think throughout the whole film, we focus on what they have in common, and their childhood, memories, and what they share - in so doing, I think we tackle and address all of those issues of race and classes, but in a much more subconscious way, in a way that doesn't hammer you in the head. The message is that we must care for each other, no matter what the background is. In my everyday life, that was the reality. Growing up with friends of different backgrounds, we don't necessarily sit together and talk about, 'So, what's it like to be Lebanese? Or what's it like to be an aboriginal Australian?' We never talked about that. So I thought, 'Let's avoid those conversations in the film and go for the similarities...'.")

Giống như Đỗ, Howard Vũ vật lộn với quá khứ để làm rõ những điều anh không còn nhớ rõ ràng nữa. Trong phim ngắn "Running in Tall Grasses-Chạy Trong Cỏ Cao,"xxvii cũng là luận án cao học ngành phim MFA của anh tại Đại học University of Southern California, Vũ ôn lại lần đầu đi thăm nuôi $\mathrm{Ba}$ đầy xa lạ, và nhất định muốn biết tại sao Ba mình không chịu về nhà. Phim của Vũ cho thấy ký ức tuổi thơ nằm sâu trong tâm thức của thế hệ 1.5 . Phim đoạt giải the Jeffrey Jones Scholarship for Excellence in Writing, và giải the American Society of Cinematographers Conrad L. Hall Heritage Award. Chào đời tại Sài Gòn vài tháng trước khi miền Nam thất thủ, Vũ đã "thật sự 'sinh hụt' cái thời 70 như dân xứ Mỹ vẫn nói." Nhưng, anh 
Trangdai Glassey-Tranguyen- Biểu Đạt Căn Tính Di Dân trên Quê Huoong Việt-Mỹ và tại Hải Ngoại

vẫn trân quý những năm đầu đời ở Sài Gòn và chuyến vượt biên với gia đình đến các trại tỵ nạn tại Mã Lai Á, nơi mà anh “đã học đòi ghiền kẹo dừa và mê những bãi biển mưa giăng." Vũ thu thập nhiều kinh nghiệm trước khi vào ngành phim, từ việc đi giao pizza, lập mã chương trình vi tính, nhận những công việc về graphic design. Những kinh nghiệm này gíup cho cách dựng phim của anh thêm tính thực tế. Trong khi theo học ngành Phim và Truyền Hình tại Đại học University of Southern California, Vũ đoạt giải the Cinema Circulus Endowed Scholarship, và nhiều giải khác. Về phim ngắn "Chạy Trong Cỏ," Vũ nhận xét (Tranguyen, 2004b) (tác giả chuyển ngữ),

Kịch bản phim đến từ một câu chuyện nhỏ tôi viết nhiều năm trước, khi tôi mới bắt đầu mơ hồ nhận ra rằng tôi còn nhớ rất ít về những năm niên thiếu của mình ở Việt Nam. Cậu bé trong phim, tên Vinh, bắt được những thoáng qua của một thế giới nguy hiểm và phức tạp hơn nhiều so với thế giới mà cậu đã biết... Cuộc sống đối với Vinh và cha mẹ cậu sẽ tiếp tục, và gia đình cậu sẽ cố gắng hết mình trong mọi hoàn cảnh. Chế độ mới tiếp thu miền Nam sau khi Sài Gòn thất thủ năm 1975 đã bắt giam hàng trăm người bị coi là nguy cơ chính trị đối với chính quyền mới tại các trại tập trung lao động để 'cải tạo' họ về mặt ý thức hệ. Những người này là cựu quân dân cán chính, văn nghệ sĩ, phóng viên, và các vị lãnh đạo tôn giáo. Nhưng tất cả những điều này đối với cậu bé Vinh chỉ đơn giản là việc cha cậu đã vắng nhà một thời gian dài.

(Nguyên văn Anh ngữ: "It comes from a little story that I wrote a number of years ago, when I first had the inkling that I remember very little clearly from my early years in Vietnam. The boy in the film, named Vinh, catches his first glimpse of a world that is far more dangerous and complicated than the one he has known.... Life for him and his parents will continue, and they will try to do their best under the circumstances. The new regime that took over after the fall of Saigon in 1975 sent hundreds of people deemed politically dangerous to reeducation camps to 'reform' them, ideologically. These people were former officers, artists, journalists, and religious leaders. But what all of this means to the boy is simply that his father has been absent for a long time.")

Những ký ức tuổi thơ này - cho dù in đậm trong tâm hồn một người - cũng có thể phôi phai. Vũ trầm ngâm,

Phim này rất chủ quan ở nhiều cách, và điều thú vị là khán giả sẽ không nhất thiết biết liệu những biến cố nào được xây dựng trong phim là 'có thật.' Tôi muốn đi đến cảm giác 'có phải chuyện đã thật sự xảy ra như vậy?' mà người ta có đối với những ký ức ấu thơ. Điều kỳ lạ là: trong thế giới hậu chiến Việt Nam, tất cả những điều này đã rất có thể xảy ra.

(Nguyên văn Anh ngữ: "The film is very subjective in a lot of ways, and what's interesting is that most of the audience will not necessarily know whether certain events depicted in the film are 'real.' I wanted to get at a certain 'did it really happen that way?' feel that people have from early childhood memories. The strange thing is: in the world of post-war Vietnam, all of it could very well have happened.")

\section{Âm hưởng Chiến Tranh trong di-dân-tính Refug-endity hải ngoại}

“Thật” hay "hư,” những hình ảnh và ký ức này chứng tỏ nó mạnh mẽ và bền bỉ, và trong một 
Trangdai Glassey-Tranguyen- Biểu Đạt Căn Tính Di Dân trên Quê Huơng Việt-Mỹ và tại Hải Ngoại

cách nào đó, nó còn chế ngự những khoảng cách đáng lo ngại giữa thế hệ và rào cản ngôn ngữ vốn gây khó khăn cho mối tương quan giữa những thế hệ người Mỹ gốc Việt và các gia đình di dân thiểu số khác. Hoàn cảnh hậu chiến tại Việt Nam càng làm mọi việc rắc rối hơn. Vũ chào đời khi $\mathrm{Ba}$ anh đã bị bắt đi và bị giam ở trại cải tạo. Là một đứa bé, anh không quan tâm đến cái bất công chính trị mà thế hệ cha mình phải đối diện, nhưng anh nổi giận với cái bất công không được sống với $\mathrm{Ba}$ (Tranguyen, 2004b) (tác giả chuyển ngữ):

Đây không phải là phim chiến tranh, tuy chứng cứ của tranh chấp còn đọng lại. Nét chính trị bên trong thì không thể chối bỏ, nhưng đó không phải là mâu chốt. Tôi không muốn luận chiến, hay hô hào một cách tuỳ tiện. Nó đơn giản như thế này: cái nhìn của một cậu bé, lần đầu tiên thấy cha mẹ mình trong đường nhắm sắt gọn. Họ ở đó, hai người yêu trẻ, có khi can đảm nhưng cũng có lúc si khờ. Hoàn cảnh, bối cảnh của việc khám phá này, đến qua sự ráp nối những ký ức cá nhân của tôi được gạn lọc qua nhiều năm nằm mơ không có kết cục. Tôi thử giải mã những hình ảnh mà tôi có, để tìm đến cái trục tình cảm của chúng.

(Nguyên văn Anh ngữ: "This is not a war film, but the evidence of that conflict remains like a residue. The politics underneath are undeniable, but they are not the main focus. I do not want polemics, or convenient sloganeering. It is simply this: a boy's point of view, seeing his parents in sharp focus for the first time. They are there, young lovers, sometimes foolish and sometimes brave. The context, the situation of this discovery, comes through a composite of first-person memories heavily filtered through years of inconclusive dreaming. I am attempting to process these images that I have, to get to their emotional core.")

Tìm về quá khứ và ký ức cần sự chiêm niệm cao - hay 'mơ không kết cục' theo cách nói của Vũ - và những biểu hiện mới mẻ, mà như Vũ nói, "để ghi lại kết cấu của ký ức, ấn tượng và ngay cả không đáng tin." Những nghệ sĩ thuộc thế hệ chào đời và lớn lên sau khi cuộc chiến Việt Nam kết thúc như Vũ phải đôi co với những dấu vết chiến tranh và những tranh chấp lan tràn trong tâm thức/tiềm thức của họxxviii. Giống như những người cùng thế hệ mình, các hoạ sĩ như Bình Danh và Danh Võ đã thử và thành công trong việc làm cho những dấu vết chiến tranh trở nên có thể thấy được và có thể chạm được. Trong nhiều dự án khác nhau của Bình Danh, ký ức chiến tranh Việt Nam luôn chiếm chỗ giữa. Anh sinh tại Việt Nam, và sáng tác của anh đặt câu hỏi về di sản Việt Nam của mình và ký ức cộng thông của chiến tranh. Danh tốt nghiệp cao học Mỹ thuật MFA tại Đại học Stanford năm 2004. Anh bắt đầu được chú ý trên toàn quốc với những tác phẩm nhìn về văn hoá Việt Nam và ký ức chiến tranh của cộng đồng, cả ở Việt Nam và Cambốt. Danh mô tả tác phẩm của mình là có liên quan đến "cái chết, ký ức, lịch sử, phong cảnh, công bằng, bằng chứng, và tâm linh." Danh chế ra cách in trên lá (chlorophyll printing process), dùng quang hợp để hình ảnh hiện ra trong gân lá. Gần đây anh chú trọng vào kỹ thuật Daguerreotype. Tác phẩm của Danh được trưng bày ở những cuộc triển lãm quan trọng tại các viện bảo tàng khắp nước $\mathrm{Mỹ}$, cũng như trong các bộ sưu tập của Corcoran Art Gallery, The Philadelphia Museum of Art, the deYoung Museum, và the George Eastman House, cùng nhiều nơi khác. Anh nhận được học bổng 2010 Eureka Fellowship từ the Fleishhacker Foundation, và được đại diện bởi Haines Gallery ở San Francisco, CA và Lisa Sette Gallery ở Scottsdale, AZ. Một trong những dự án của anh, "Cái Chết, Những Mảng Vỡ của Chiến tranh Việt Nam và Hoa Kỳ" ("Immortality, The Remnants of the Vietnam and American War"), diễn đạt sự tiếp nối của chiến tranh qua hình ảnh chiến tranh trên lá. Danh giải thích ${ }^{\text {xxix }}$ (tác giả chuyển ngữ), 
Trangdai Glassey-Tranguyen- Biểu Đạt Căn Tính Di Dân trên Quê Huoong Việt-Mỹ và tại Hải Ngoại

Tôi đã ghi lại những hình ảnh của chiến tranh Việt Nam trên và trong lá cây nhiệt đới. Một mùa hè nọ, tôi nôn nao thử nghiệm với quang hợp và những sắc tố còn lại sau khi thấy cỏ đổi màu dưới một ống nước bỏ ngoài sân. Ngay sau đó, tôi làm những bản in trên lá. Trong nghệ thuật của tôi, quang hợp được sử dụng để ghi lại hình ảnh trên lá chỉ với chất diệp lục và ánh sáng: nguồn sống của cây cối và, do đó, cũng là nguồn sống trên trái đất. Lá được tạc lên nhựa cây, như những mẫu thí nghiệm sinh học.

(Nguyên văn Anh ngữ: "I have recorded the images of the Vietnam War onto and into tropical plants. One summer, I was motivated to experiment with photosynthesis and its pigments after observing how grass changed color under a water hose that was left on the lawn. Soon after that, I was making chlorophyll prints. In my work, photosynthesis is used to record images onto leaves using only chlorophyll and light: the life source of plants and, consequently the Earth. The leaves are then cast in resin, like biological samples for scientific studies.”)

Trong một dự án khác cũng liên quan đến Việt Nam, "Ikea, Made in Viet Nam," Danh suy nghĩ về những mấu nối liên không gian của đồ vật và ký ức (tác giả chuyển ngữ).

Ngày kia, khi đang ở tiệm IKEA, tôi để ý thấy vài sản phẩm IKEA mang hình dạng thú vị và những hình dạng này giúp tôi liên tưởng đến lịch sử của tôi. Tôi ngạc nhiên khi biết rằng những sản phẩm này được làm ở Việt Nam. Nên tôi mua vài món về và sắp xếp thành một tác phẩm installation để nói đến những ký ức bền bỉ của chiến tranh Việt Nam. (Nguyên văn Anh ngữ: "One day while visiting an IKEA store, I took notice of some IKEA products that have an interesting shape and form that for me connect these forms to my history. I was then surprised to find that these items were made in Viet Nam. So I bought several of these items and arranged them in an installation to suggest the persistent memories of the Vietnam War.")

In trên lá là kỹ thuật độc quyền của Danh, diễn đạt thật lưu loát về quá khứ và những gì đọng lại, và làm thế nào chính những quá khứ và chất đọng lại này di chuyển qua thời gian, thế hệ, và không gian. Theo lời của Danh (tác giả chuyển ngữ):

Quá trình này tác hợp với ý niệm về sự di dịch của yếu tố: sự phân huỷ và tạo thành của sự vật thành những hình dạng khác. Những hình ảnh chiến tranh là một phần của những chiếc lá, và sống bên trong và bên ngoài chúng. Những chiếc lá biểu hiện sự tiếp nối của chiến tranh. Chúng chứa đựng những gì còn đọng lại của cuộc chiến Việt Nam: bom, máu, mồ hôi, nước mắt, và kim loại. Người chết đã được kết hợp vào đất đai Việt Nam trong chu kỳ sinh ra, sống, và chết; qua sự tái tạo và chuyển hoá của vật liệu, và sự tạo thành của những vật liệu mới. Vì vật chất không tự sinh ra hay mất đi, mà chỉ chuyển hoá, những mảnh vụn của cuộc chiến Việt Nam và Hoa Kỳ còn sống mãi trên những miền đất Việt Nam.

(Nguyên văn Anh ngữ: "This process deals with the idea of elemental transmigration: the decomposition and composition of matter into other forms. The images of war are part of the leaves, and live inside and outside of them. The leaves express the continuum of war. They contain the residue of the Vietnam War: bombs, blood, sweat, tears, and metals. The dead have been incorporated into the landscape of Vietnam during the cycles of 
Trangdai Glassey-Tranguyen- Biểu Đạt Căn Tính Di Dân trên Quê Huoong Việt-Mỹ và tại Hải Ngoại

birth, life, and death; through the recycling and transformation of materials, and the creation of new materials. As matter is neither created nor destroyed, but only transformed, the remnants of the Vietnam and American War live on forever in the Vietnamese landscape.")

Thật vậy, những mảnh vỡ của chiến tranh còn mãi, và chính khi hồi tưởng thì người hoạ sĩ chuyển hoá quá khứ và hiệu triệu tương lai. Như Bình Danh, Danh Võ thăm lại quá khứ qua kinh nghiệm cá nhân, và dù anh tách mình ra khỏi tác phẩm của mình, anh đã đưa quá khứ đứt đoạn của cá nhân và của lịch sử đến với nhau. Sinh năm 1975 tại Bà Rịa, Vũng Tàu, và đến đảo Phú Quốc trong cùng năm đó, Võ vượt biển với gia đình năm 1979 và được tàu thuỷ của hãng Maersk của Đan Mạch vớt. Gia đình định cư tại Đan Mạch. Võ theo đuổi nghệ thuật, và học tại the Royal Danish Academy of Fine Arts ở Copenhagen trước khi theo học trường Städelschule ở Frankfurt, và đã sống và làm việc Berlin từ năm 2005. Võ đã có những cuộc triển lãm quốc tế, như tại the Art Institute of Chicago vào năm 2012-2013; Kunsthaus Bregenz, Vương quốc Áo năm 2012; National Gallery of Denmark tại Copenhagen vào năm 2012 \& 2010; Kunsthalle Basel, Thuỵ Sĩ, năm 2009; MoMA, New York năm 2009; Stedelijk Museum, Amsterdam năm 2008; Bergen Kunsthall, Na Uy năm 2006; the Shanghai Biennial năm 2012; the 2013 Venice Biennale; the Museion ở Bolzano, Ý Đại Lợi năm 2013; và the Guggenheim Museum ở New York năm 2013, etc. Võ đã từng là nghệ sĩ thường trú tại the Villa Aurora ở Los Angeles năm 2006, vài tại Kadist Art Foundation thuộc Paris năm 2009, bên cạnh các nơi khác.

\section{Việt Nam, Một Người Di Tản Liên Quốc Gia: Từ Cá Thể đến Chính Thể}

Nếu Howard Vũ dựng phim từ những năm đầu tiên ngắn ngủi nhưng đáng nhớ của mình ở Việt Nam, Danh Võ dựa trên văn khố lịch sử để đối diện với quá khứ cá nhân của mình và lịch sử quốc gia của Việt nam. Trong cuộc triển lãm "Tiếng Mẹ Đẻ” (tôi dịch từ tựa đề "Mother Tongue") từ ngày 20 tháng Ba đến 27 tháng Tư, 2013 tại New York, người xem gặp gỡ lịch sử qua cái nhìn cá nhân. Chẳng hạn như tác phẩm "LOT 40. GULF OF TONKIN RESOLUTION, 2013," là ngòi viết máy - một công cụ mang tính đặc trưng đã bao lần viết lên vận mệnh của Việt Nam từ thời Pháp thuộc đến giai đoạn Mỹ bảo trợ. Danh Võ dùng ngòi bút này - một vật tự bản thân đã mang tính lịch sử trong thời đại kỹ thuật số của chúng ta - qua tài viết của cha anh, ông Phung Võ, và là vật thể chính trong tác phẩm "LOT 40. GULF OF TONKIN RESOLUTION, 2013.” Đây là đoạn văn đi kèm (chữ hoa được dùng trong bản gốc; tôi chọn không dịch trích đoạn này để phản ánh tính lịch sử và ngoại quốc của nó, và tôi coi nguyên cả văn bản trích đoạn này như một vật thể không nên bị thay đổi qua việc chuyển ngữ):

ON 2 AUGUST 1964 THE USS MADDOX, WHILE ON AN ELECTRONIC INTELLIGENCE COLLECTION MISSION, WAS ATTACKED BY THREE NORTH VIETNAMESE TORPEDO BOATS. TWO DAYS LATER, ACCORDING TO MCNAMARA'S REPORT, "NORTH VIETNAMESE BOATS AGAIN ATTACKED OUR DESTROYERS [THE MADDOX AND TURNER JOY] ... ON AUGUST 5, U.S. PLANES RETALIATED IN A LIMITED FASHION AGAINST NAVAL BASES WHERE WERE THE HOME PORTS OF BOATS AND THE OIL STORAGE AREA AT VINH WHICH SUPPORTED THEM ... THE U.S. RETALIATION DID NOT EXTEND BEYOND AUGUST 5." A LATER INVESTIGATION BY THE SENATE FOREIGN RELATIONS COMMITTEE LEARNED THAT THE U.S. NAVAL 
Trangdai Glassey-Tranguyen- Biểu Đạt Căn Tính Di Dân trên Quê Huơng Việt-Mỹ và tại Hải Ngoại

COMMUNICATION CENTER IN THE PHILIPPINE ISLANDS, IN REVIEWING SHIPS' MESSAGES, QUESTIONED WHETHER A SECOND ATTACK HAD ACTUALLY OCCURRED. THE BALANCE OF THE MEMO RECOUNTS NUMEROUS ACTS OF TERRORISM PERPETRATED BY THE VIET CONG AGAINST SOUTH VIETNAMESE CITIZENS AND U.S. PERSONNEL. AFTER LENGTHY DEBATE, CONGRESS VOTED ON 10 AUGUST 1964 ON A JOINT RESOLUTION WHICH AUTHORIZED THE PRESIDENT "TO TAKE ALL NECESSARY STEPS, INCLUDING THE USE OF ARMED FORCE, TO ASSIST ANY MEMBER OR PROTOCOL STATE OF THE SOUTHEAST ASIA COLLECTIVE DEFENSE TREATY REQUESTING ASSISTANCE IN DEFENSE OF ITS FREEDOM." THE RESOLUTION IS OF HISTORICAL SIGNIFICANCE BECAUSE IT AUTHORIZED THE PRESIDENT, WITHOUT A FORMAL DECLARATION OF WAR BY CONGRESS, FOR THE USE OF CONVENTIONAL MILITARY FORCE IN SOUTHEAST ASIA. WHILE MCNAMARA'S MEMO REPRESENTS THE PRESIDENT'S WILLINGNESS TO NEGOTIATE A PEACE WITH THE NORTH VIETNAMESE, THE ADMINISTRATION RELIED UPON THE RESOLUTION TO BEGIN ITS RAPID ESCALATION OF U.S. MILITARY INVOLVEMENT IN SOUTH VIETNAM AND OPEN WARFARE IN NORTH VIETNAM. (THE WHITE HOUSE YEARS OF ROBERT S. MCNAMARA: SOTHEBY'S, 2012.)

Trích đoạn trên cho thấy Việt Nam - qua những quan hệ và chính sách từ cuộc chiến Việt Nam - đã mang tính liên quốc gia vì đất nước này luôn dính líu đến những biến cố ở ngoài lãnh thổ và những việc nội bộ của mình. Một tác phẩm sắp xếp cũng khá nổi bật khác của Võ nói về ảnh hưởng ngoại quốc lên Việt Nam có tên "Go Mo Ni Ma Da"xxx. Tự bản thân cái tựa đã nói lên được sự can thiệp của phương Tây trong lịch sử Việt Nam. Một ký giả Mỹ đã được chào với cụm từ "Go Mo Ni Ma Da" — có nghĩa là "Good morning, Madame" — trong thời gian bà ở Việt Nam và đã đưa cụm từ này vào bài báo. "Go Mo $\mathrm{Ni} M a \mathrm{Da}$ " bao gồm bốn phần: "We The People" với bản sao cùng kích cỡ của tượng Nữ Thần Tự Do năm 1886 của Auguste Bartholdi, ba đèn pha lê từ Khách sạn Majestic, một tác phẩm nói về vị Linh mục thừa sai Công giáo Théophane Vénard (1829-1861), và những món mua được từ cuộc đấu giá Sotheby cho Bất Động Sản của Robert $\mathrm{S}$. McNamara. Cái tựa đề đa ngữ và những hiện vật mang tính lịch sử trong giai đoạn lịch sử Việt Nam gần đây đã đặt Việt Nam và phương Tây bên cạnh nhau, cả hai trong một quan hệ tương tác (như bộ đèn pha lê bao hàm căn phòng họp ở Khách sạn Majestic, nơi mà Hoa Kỳ và Việt Nam ký Hiệp Định Paris năm 1973, hoặc Théophane Vénard là một thí dụ của việc truyền đạo Công giáo đến Việt Nam trong thời Pháp thuộc vào thế kỷ 17) và trong không gian độc lập với nhau (We The People như một lý tưởng của Mỹ và Tây phương, hoặc bất động sản của McNamara). Tôi thấy việc Võ chọn cụm từ này làm tựa của cuộc triển lãm thật thú vị và đầy thuyết phục: một cụm từ của phương Tây đã được Việt Nam hoá, nhưng vẫn phản ánh gốc tiếng Pháp và tiếng Anh. Cái nhìn là từ phía Tây, và việc Việt Nam hoá nó có thể được coi như một hình thức phản kháng hoặc thích nghi qua việc sát nhập và địa phương hoá những từ ngữ phương Tây. Tôi cho rằng tính đối ngẫu của thống trị/ảnh hưởng và phản kháng/Việt hoá là chìa khoá trong cách Võ biểu đạt cách Việt Nam thương lượng thân phận của mình như một quốc gia trong chính trị thế giới trong quá khứ (và dĩ nhiên, với những ảnh hưởng đến nay). Qua đó, không chỉ dân tộc Việt Nam trở thành di dân, mà Việt Nam như một quốc gia cũng đã và vẫn là một người di dân trong những điều đình chính trị diễn ra ở phương Tây hay tại Việt Nam. Qua 
Trangdai Glassey-Tranguyen- Biểu Đạt Căn Tính Di Dân trên Quê Huoong Việt-Mỹ và tại Hải Ngoại

tác phẩm của Võ, người xem gặp gỡ một Việt-Nam như một người di-dân-liên-quốc-gia xuyên qua nhiều giai đoạn lịch sử.

Từ cái chính thể (the political) và quốc thể (the national) đến cá thể (the personal), sức mạnh của ký ức và kinh nghiệm sống là điều không ai có thể trốn tránh được. Ngay cả khi phụ huynh khuyến khích con em mình chỉ nói tiếng Anh dưới áp lực và thao thức hội nhập, bản sắc văn hoá lại cuồn cuộn nổi sóng khi những thế hệ bắc cầu đến tuổi trưởng thành và đi tìm nhân diện của mình, như trong trường hợp của Hàm Trần (Glassey-Tranguyen, $2011 \mathrm{~d} \&$ 2012c), đạo diễ்n của bộ phim đoạt nhiều giải thưởng Vươt Sóng ${ }^{x x i}$ - bên cạnh các phim có tiếng khác. Trần kể lại việc ba anh - vì lòng biết ơn đối đất nước đã cưu mang gia đình anh giữa lúc khốn cùng đã khuyến khích con cái theo đạo Tin Lành và văn hoá Mỹ. Nhưng tuổi thơ của Trần ở Việt Nam, vùng Little Saigon sung mãn và đầy quyến rũ ngay gần nơi gia đình anh đang sống ở Santa Ana, và sự trưởng thành trong môi trường đại học đã làm cho Trần không thể nào quên gốc gác (Glassey-Tranguyen \& Trần, 2011; Glassey-Tranguyen, 2012d).

Một việc quan trọng và có lẽ ít ai biết về Trần là anh 'mê' gia đình. Đó là cốt lõi cho đời sống và tác phẩm của anh, từ các phim ngắn đầu tay ${ }^{x x x i i}$ cũng như phim-thành-danh Vươt Sóng. Phim của anh luôn xoay quanh cuộc sống gia đình hằng ngày, những khung cảnh đời thường thân quen, đăm đắm về những kỷ niệm ấu thơ đã khắn sâu trong tâm khảm, những tình cảm gia đình khắn khít nương tựa vào nhau, sống chết có nhau trong những lúc khốn khó nhất. Nhưng chính những mắc xích đơn sơ ấy lại tạo nên những bức tranh kỳ vĩ, giúp thế giới hiểu về một giai đoạn lịch sử cận đại nhiều thăng trầm và đầy can trường của người dân Việt trên màn ảnh bạc. Nói về Hàm Trần là nói về đời sống của một cậu bé lớn lên ở Chợ Lớn; về những buổi sáng thức dậy trong mùi thơm nồng nàn của sạp cơm tấm của Bà Nội; về những đêm khuya cậu bé đứng bên mẹ trong đêm trăng, cạnh cái cổng sắt trước căn nhà cuối hẻm, lặng lẽ chờ ba còn đi làm ăn giao tiếp chưa về; về những âm và vị của Sài Gòn và của di sản đa văn hoá của $\operatorname{anh}^{\text {xxxiii }}$. Tất cả những kinh nghiệm sống này được thể hiện trong tính thực tế của những tác phẩm điện ảnh của Trần: luôn luôn đời thường, luôn luôn 'thật' (để quay lại với suy tư của Khoa Đỗ và Howard Vũ), luôn luôn nói về gia đình, luôn luôn gần gũi với những ai đã từng sống ở Việt Nam. Trần dùng kinh nghiệm và cái nhìn của mình để dựng những phim ngắn, như Ngày Gi î̃, nhưng cho phim tầm vóc Vượt Sóng, Trần phỏng vấn hàng trăm người Việt tỵ nạn và tạo ra một câu chuyện chung rất lôi cuốn và cần thiết như phim này. Qua đời sống của người dân Việt, Trần dựng lại đời sống của Việt Nam trong hậu bán thế kỷ hai mươi mốt.

\section{Refug-endity: "Mái ấm" trên quê hương Việt-Mỹ VietnAmerica}

Nói về gia đình là gợi lên hình ảnh 'mái nhà.' Mái nhà chưa bao giờ là một khái niệm cứng ngắc hoặc đứng yên, mà là cả một thế giới luôn vận hành và phức tạp, nơi kinh nghiệm con người khai mở. Trong tác phẩm của mình (Glassey-Tranguyen, 2013c), nghệ sĩ quốc tế đa năng đa dạng Việt Hồ Lê (tái) thẩm định khái niệm 'mái nhà' qua chính kinh nghiệm một người tỵ nạn và ký ức về cơn bệnh và cái chết của người cha khuyết tật. Gia đình của Lê vượt biên và ở tại trại tỵ nạn Thái Lan khi anh mới hai tuổi, nhưng anh "không nhớ gì về chuyến vượt biên, hay của trại tỵ. nạn Thái Lan. Ký ức đầu tiên là đi máy bay từ Thái Lan qua Mỹ” (Nguyên văn Anh ngữ: "I had no real memories of the boat escape, of the Thai refugee camps. My first recollection is of getting on a plane from Thailand to the United States.") Như những người tỵ nạn khác, gia đình của Lê vất vả kiếm sống trong những ngày đầu định cư, "Khi mới tới Mỹ, gia đình ở chung với một gia đình khác ở Garden Grove. Sau đó gia đình Việt dọn ra ở một căn hộ riêng nhưng vẫn trong Quận Cam. Sau giờ học, Việt đi skate với bạn trong xóm là Ngân và Phiêu” (Nguyên văn 
Trangdai Glassey-Tranguyen- Biểu Đạt Căn Tính Di Dân trên Quê Huoong Việt-Mỹ và tại Hải Ngoại

Anh ngữ: "When we first arrived in the United States, my family shared a house with another family in Garden Grove. We later moved to our own apartment in Orange County. After school, I would skate with the neighborhood kids, Ngan and Phieu.") Gia đình anh làm việc cật lực để sống còn - không chỉ về mặt tài chánh, mà cả về việc học của Lê. Anh nhớ lại (tác giả chuyển ngữ),

Cả nhà vất vả vì là người di dân; Mẹ và Việt may gia công ở nhà. Sau một ngày làm việc mệt nhọc, Ba về nhà và giúp Việt làm bài tập về nhà. Cho đến lúc hăm mấy tuổi, Việt mới biết là hồi nhỏ, đáng lẽ Việt phải học trễ một lớp vì yếu tiếng Anh. Ba đã 'bí mật' đồng ý với cô giáo là sẽ dạy kèm cho Việt ở nhà.

(Nguyên văn Anh ngữ: "We struggled as immigrants; my mother and I did sweatshop work at home sewing garments. After an exhausting day at work my father would come home and help me with my homework. I did not find out until my twenties that I was to be held back a grade due to my poor English. My dad had made a 'secret' agreement with my teacher that he would tutor me.

Lê là một 'người tỵ nạn' trong nhiều nghĩa: sắc tộc, giới tính, và khuynh hướng nghệ thuật. Khi còn nhỏ, anh bị miệt thị vì những khác biệt của mình (tác giả chuyển ngữ),

Tuy ở trường và trong xóm có nhiều người thiểu số, nhưng Việt vẫn thuộc số ít. Ban đầu, cô giáo không nói được tên của Việt. Dù vậy, các thầy cô ở trường tiểu học nâng đỡ Việt rất nhiều. Cô giáo lớp Sáu hay khuyến khích Việt vẽ tranh. Ở cấp hai, Việt khổ sở vật lộn ở cái ngã tư mà căn tính sắc tộc và xu hướng tính dục giao nhau. Một số bạn học đã chế nhạo gọi Việt là 'đồ lại cái' khi Việt đi bộ đến trường mỗi ngày.

(Nguyên văn Anh ngữ: "Although there was diversity in school and neighborhood growing up, I was still a minority. At first some of my teachers couldn't pronounce my name. My teachers at my elementary school, however, were very supportive. My sixth grade teacher really encouraged my drawings. In middle school, it was the intersection of ethnicity and sexuality that I had trouble grappling with. Some other classmates would taunt me for being a 'pansy' as I walked to school each day.")

Anh còn nhớ mình bị người ta mắng chỉ vì những màu sắc anh sử dụng (tác giả chuyển ngữ):

Khi học cử nhân, Việt có đi sơn cửa sổ cho bưu điện trong vùng để kiếm tiền thêm trong mùa Giáng Sinh. Thường thì sơn Ông già Noel, đèn cầy, và người tuyết. Bữa đó đang sơn thì có một cựu quân nhân người Mỹ nói với Việt về đèn cầy đỏ và ánh lửa màu vàng Việt đang sơn, 'Mấy cái màu đó không phải là màu của nước tao, mà là màu của nước mày'." (Nguyên văn Anh ngữ: "As an undergraduate I would paint holiday windows for the local post office for extra cash. Often, it was cheery Santas, candles and snowmen. As I was painting one day, an American veteran said to me about the red candles and yellow flames I was painting, 'Those colors are not the color of my country, but the colors of your country (referring to the colors of the Vietnamese flag, red and yellow)."')

Dù khuyết tật, Ba của Lê đã tốt nghiệp cao học ở Mỹ, và làm việc để nuôi sống gia đình, cũng như có thơ đăng trên báo tiếng Việt. Khi Ba bệnh, Mẹ của Lê gánh vác mọi trách nhiệm 
Trangdai Glassey-Tranguyen- Biểu Đạt Căn Tính Di Dân trên Quê Huoong Việt-Mỹ và tại Hải Ngoại

trong nhà và chăm sóc cho ông. Hành trình chống chọi với bệnh tật và cái chết của ông đã làm cho gia đình đến gần nhau hơn (tác giả chuyển ngữ),

Khi Ba nằm liệt giường trong hơn hai năm trời, Việt đang học cao học Mỹ thuật và đã dọn ra riêng. Cùng lúc đó, Việt cũng một phen hú vía vì tưởng bị ung thư, và cũng bệnh nặng. Mẹ phải chăm sóc cho $B a$ và gánh vác gia đình. Lúc đó, Việt về thăm nhà mỗi cuối tuần để giúp đỡ $\mathrm{Ba} M e ̣$. Trong thời gian đó, Việt gần gũi với Ba hơn, dù trước đó giữa hai cha con có một khoảng cách. Sau khi Ba mất, Việt cố gắng giữ lại ký ức về $\mathrm{Ba}$, hình dung ra cái tâm của $\mathrm{Ba}$ khi Việt đi bộ một mình. Khi Ba bệnh nặng, Việt chụp hình của gia đình $^{\text {xxxiv }}$ (cũng như hình những gia đình khác đối diện với bệnh chí tử và cái chết). Việt muốn tìm hiểu về sự mất mát và việc chúng ta chưa có nhiều cách để đối diện với cái chết trong xã hội dòng chính.

(Nguyên văn Anh ngữ: "When my father became bedridden over two years, I was pursuing my MFA and lived away from home. During the same time, I also had a painful cancer scare, so was also physically ill. My mother had to nurse my father and uphold the household. Then, I would visit my family every weekend to try to help. During that time, I became closer to my father, with whom I previously had a somewhat distant relationship. After he passed away, I try to actively keep his memory alive, to envision his spirit when I take hikes by myself. When my father was very ill, I started to take photographs of my family ${ }^{\mathrm{xxv}}$ (as well as other families grappling with terminal illness and death). I wanted to explore loss and the lack of avenues we have for dealing with death in mainstream society.")

\section{Refug-endity: Tình Yêu và Mất Mát}

Khi vào đại học, Lê học về mỹ thuật và vào chương trình Cao đẳng Mỹ thuật tại UC Irvine. Luận án cao học MFA của anh được đánh giá cao, "bao gồm những bức hình lớn, tĩnh lặng của gia đình Việt, những hình ảnh từ bên trong của gia đình đang vất vưởng với căn bệnh mãn tính của Ba. Gần đây, một bức hình trong bộ hình này được chọn cho giải Sovereign Art Prize, một giải có tầm vóc lớn" (Nguyên văn Anh ngữ: "included quiet, large scale photographs of my family, interiors and of my family's struggle with my father's terminal illness. Recently, an image from that series was chosen Sovereign Art Prize, a high-profile recognition.”) Tuy làm hoạ sĩ thì hơi gian nan về tài chánh, nhưng Lê tận tuỵ với nghệ thuật, tình yêu thứ nhất của mình (tác giả chuyển ngữ),

Việt luôn cảm thấy vinh hạnh và cảm kích có được cơ hội để chia sẻ sáng tác của mình cũng như những tác phẩm của các nghệ sĩ mình thích. Ước mơ từ nhỏ của Việt được tham gia vào những cộng đồng của những người làm văn hoá đã thành hiện thực. Đôi khi bị kẹt trong những chi li đời thường hằng ngày, Việt tưởng như quên đi cuộc hành trình kéo dài từ Việt Nam và trở về đó. Mục đích của Việt là tiếp tục nuôi dưỡng những đối thoại giữa các cộng đồng nghệ thuật.

(Nguyên văn Anh ngữ: "I am always humbled and grateful for the opportunity to share my work as well as share the works of other artists I love. My childhood wish of being a part of communities of cultural producers has become realized. Caught up with daily mundane details, sometimes I forget the long journey from Viet Nam and back again. My goal is to continue to build dialogue across communities through art.) 
Trangdai Glassey-Tranguyen- Biểu Đạt Căn Tính Di Dân trên Quê Huoong Việt-Mỹ và tại Hải Ngoại

Trong tất cả những mất mát, sự ra đi của một người thân có lẽ là sự mất mát khó nguôi ngoai nhất. Cái chết của Ba tiếp tục ám ảnh tâm trí và nghệ thuật của Việt. Ở một cách nào đó, Ba vẫn còn sống - trong một hình thức khác, qua suy nghĩ và cảm xúc được gột tả trong nghệ thuật của Việt. Việt hình dung Ba của hôm nay, một người cha mà anh đã gặp lại sau những ngày dài thương tiếc (tác giả chuyển ngữ),

Tuần trước, Việt nằm mơ thấy $\mathrm{Ba}$. Việt quên chi tiết của giấc mơ, chỉ nhớ là hai cha con ngồi nói chuyện bình thường với nhau, chuyện thường ngày. Việt vẫn còn bị xúc động mạnh khi xem phim hoặc đọc truyện về cha con và gia đình. "Ba" của hôm nay nhắc Việt nhớ về những hình thức di chuyển và những chuyển tiếp: lần đi biển qua đất Thái, chuyến bay đầu tiên tới Mỹ, không biết bao nhiêu lần lái xe đi học đi làm đi công chuyện. $\mathrm{Ba}$ nhắc Việt rằng mái nhà thì ở giữa những tiếng đồng hồ đăng đẵng và những chuyến đi xa, ở trong và giữa những chuyển tiếp, không thể diễn giải được.

(Nguyên văn Anh ngữ: "The other week, I dreamt of my father. I forget the circumstances of the dream, only that we had a regular chat, the stuff of daily life. I still get emotional when I watch films or read stories about fathers and sons, families. My "Ba" of today reminds me of the many modes of transport of transit and of transition: the barge to Thailand, my first plane to the United States, the countless car rides to work to school to run errands. He reminds me that home is in between long hours and long commutes, within and in between transit, untranslatable.")

Mùa hè năm 2009, Lê rong ruổi trên cánh đồng nghệ thuật Châu Âu, và sáng tác một chuỗi tranh cỡ lớn có tựa đề 'vết tích' ('vestige') dựa trên hình ảnh từ văn khố của những người lính tử trận cũng như hình ảnh gia đình trước chiến tranh Việt Nam. Chuỗi tranh này được vẽ trên những tấm ra giường lớn đã cũ, và nói về những bóng ma ký ức và những vết tích của tang thương. Được biết đến như một nghệ sĩ đa tài và đa năng với một tính cách đa dạng, giới tính cũng là một phần linh động trong đời sống của Lê, bởi vì (tác giả chuyển ngữ):

Như Judith Butler nói, giới tính thì được thể hiện. Lúc sáu tuổi, Việt nghĩ mình là đồng tính. Bây giờ, Việt nghĩ mình là 'queer.' Việt tin là giới tính và xu hướng tính dục thì uyển chuyển, vừa khéo léo vừa nghệ thuật. Nghệ thuật của Việt vẫn đề cập đến giới tính. Video 'sexperimental' ba phần mới nhất của Việt (vẫn đang làm) đề cập tới một cuộc tình tay ba liên quốc gia liên giới tính. Và nó tam ngữ! Trong nghệ thuật và trong cuộc sống, giới tính, sắc tộc, và bản năng tính dục chỉ là một mảng của cái tạo nên chúng ta như những cá thể luôn tiến hoá trong một dòng xoáy.

(Nguyên văn Anh ngữ: “As Judith Butler points out, gender is performative. When I was six, I thought of myself as gay. Now I identify as queer. I believe gender and sexuality is fluid, both artifice and art. My art still deals with issues of gender. My latest 'sexperimental' video trilogy (in progress) deals with a transnation transgender love triangle. And it's trilingual! In art and in life, gender, ethnicity and sexuality are just a fragment of what constitutes us as ever-evolving individuals in flux.")

Từ hành trình cá nhân như một người Mỹ gốc Việt queer, Lê đối diện với những khoảng trống giữa văn hoá lịch sử và văn hoá pop ở Châu Á (tác giả chuyển ngữ), 
Trangdai Glassey-Tranguyen- Biểu Đạt Căn Tính Di Dân trên Quê Huoong Việt-Mỹ và tại Hải Ngoại

Về mặt này, Việt đã sáng tác một chuỗi các tác phẩm về fake boy bands, nghệ thuật sắp xếp và video nhạc. Dự án boy bang/gang band gồm có hình ảnh kiểu campy (chú thích của tác giả: một hình thức trình diễn gần như tự trào) và video nhạc của faux pan-Asian boy bands và những nghệ sĩ trình diễn một mình trong nhiều kiểu hoá trang và trang phục, để tìm hiểu về những biên giới của trình diễn, khao khát (tình dục đồng tính), giới tính, khán giả, và ảnh hưởng. Cao trào của bull markets có thể báo trước sự trỗi lên của pop markets, bao gồm J-Pop, V-Pop, và hallyu (Korean Wave). Những thị hiếu của người tiêu dùng và của quốc gia có liên hệ gì với nhau? Sức quyến rũ của những biểu hiện này âm ỉ che mất những biểu hiện khác: đó là 'tuyên truyền.' Trong cái bóng của bang giao hậu Chiến Tranh Lạnh, người ta dùng 'lực mềm' trong thời khó khăn. Sự bùng nổ màukẹo ngọt ngào của văn hoá trẻ toàn Á Châu là một lớp nước sơn mỏng vốn che đậy những bất bình đẳng xã hội chính trị. Nền văn hoá pop bắt chước này tạo ra một bình phong để che giấu - và có thể cũng là một lối thoát cho - sự thật tăm tối của hiện đại hoá và những chấn thương trong lịch sử. Được thai nghén như những vật thể mỹ thuật giới hạn, dự án làm mờ đi ranh giới giữa 'mỹ thuật' và văn hoá tiêu thụ dòng chính. Dự án này tìm hiểu về quá trình văn hoá pop được tạo ra và tiêu thụ trong vùng Á Châu, tại hải ngoại, và các nơi khác.

(Nguyên văn Anh ngữ: "Towards this, I have created a series dealing with fake boy bands, installations and art music videos. The boy bang/gang band project consists of campy images and music videos of faux pan-Asian boy bands and solo performers in various guises and costumes, examining the borders of spectacle, (homoerotic) desire, gender, audience, and affect. The hyped rise of bull markets may presage the rise of pop markets, including J-Pop, V-Pop, and hallyu (Korean Wave). How are consumer and national desires linked? The wholesome appeal of these performing acts insidiously masks other agendas: it is 'popaganda.' In the shadow of post - Cold War diplomacy, it's 'soft power' for hard times. The sweet candy-colored explosion of pan-Asian youth culture is a thin veneer that obscures sociopolitical inequities. This ersatz pop provides a screen for - and perhaps also an escape from - the bleak realities of modernization and historical traumas. Conceived as limited edition fine art objects, the project blurs the line between 'high art' and mainstream consumer culture. The project examines how popular culture is created and consumed within Asia, its diasporas, and beyond.")

\section{Tương quan với Tiếng Mẹ Đẻ}

Xuyên qua quốc thể (the national) đến sử thể (the historical) và cá thể (the personal), văn nghệ sĩ Việt ngoại biên chứng tỏ tiếng Việt là một không gian quan trọng để kính ngưỡng, tham khảo, và/hoặc hồi tưởng. Việt Hồ Lê ước gì mình đã đầu tư nhiều thời gian hơn để học tiếng mẹ đẻ trước khi dự khoá huấn luyện ngôn ngữ di sản hậu đại học. Nhưng ôm ấp tiếng mẹ đẻ không phải lúc nào cũng là chọn lựa dễ chịu cho những người cầm bút gốc Việt. Chẳng hạn như nhà thơ Ocean Vương (Glassey-Tranguyen, 2014f), kính ngưỡng tiếng Việt và chỉ dùng tiếng Việt riêng với gia đình - không để làm thơ. Nhà thơ Ocean Vương sinh ở Sàigòn, Việt Nam năm 1988, và được nuôi nấng bởi những phụ nữ trong gia đình - người mẹ độc thân nuôi con, các dì, và Bà Ngoại - ở Hartford, Connecticut. Anh tốt nghiệp cử nhân Văn Chương Anh ngữ tại Đại học Brooklyn College. Vương là tác giả của hai tập thơ No (Vương, 2013) với Nxb YesYes Books, và Burnings (Vương, 2010) với Nxb Sibling Rivalry Press. Quyển Burnings nằm trong danh sách American Library Association's Over The Rainbow và được dùng rộng rãi trong các trường đại 
Trangdai Glassey-Tranguyen- Biểu Đạt Căn Tính Di Dân trên Quê Huoong Việt-Mỹ và tại Hải Ngoại

học tại Mỹ và các nước khác. Ocean nhận giải Pushcart năm 2013, bên cạnh các vinh dự khác như học bổng từ Kundiman, Poets House, và the Saltonstall Foundation For the Arts, cũng như Academy of American Poets Prize và Connecticut Poetry Society's Al Savard Award. Thơ của Anh đã xuất hiện trong Denver Quarterly, Quarterly West, Passages North, Guernica, The Normal School, Beloit Poetry Journal, Crab Orchard Review, Best of the Net 2012 và the American Poetry Review, vốn trao cho Anh giải Stanley Kunitz Prize năm 2012. Tác phẩm của Anh đã được chuyển ngữ sang tiếng Hindi (Bắc Ấn), Đại Hàn, tiếng Việt, và tiếng Liên Xô.

Tuy Vương chào đời mười ba năm sau khi chiến tranh Việt Nam kết thúc, nhưng lịch sử gia đình đã đặt Anh ngay vào giữa cuộc chiến - với công việc mà Bà Ngoại của Anh đã làm để sống còn, với những cái chết của những người nam trong gia đình, và mọi việc khác. Nhưng Anh bắt đầu ý thức về chiến tranh Việt Nam và tự mình vật lộn trong một quan hệ cá nhân với cuộc chiến (tác giả chuyển ngữ):

...khi tôi cứ thấy người Việt, thường được đóng bởi những diễn viên da trắng với khuôn mặt vàng, bị John Wayne bắn trên màn hình TV. Tôi nghĩ thật là kỳ quặc khi nhiều người Việt bị bắn chết bởi 'người tốt.' Tôi nghĩ tôi phải là một 'người xấu.' Nên tôi đi thư viện để thử tìm hiểu xem tôi xấu như thế nào. Đó là khi tôi khám phá ra sách và chữ. Và qua sách, tôi biết rằng bạn có thể dùng chữ để biến một người thành người tốt hay người xấu. Như thể ảo thuật.

(Nguyên văn Anh ngữ: “....when I kept seeing Vietnamese people, often played by white actors in yellow face, get gunned down by John Wayne on the television. I thought it was odd that so many Vietnamese people were being killed by 'good guys.' I thought I must be a 'bad guy.' So I went to library to try to find out what was so bad about me. This was where I discovered books and words. And through books, I learned that you can use words to make anyone be a bad guy or good guy. It was kind of like magic.")

Rời Việt Nam khi còn rất nhỏ, Vương (tác giả chuyển ngư)

...không nhớ gì cả. Tôi đến Mỹ khi mới một tuổi rưỡi. Tuy nhiên, tôi đã về thăm Việt Nam lần đầu năm 2009. Đó là một kinh nghiệm kinh hoàng, vì những gì tôi biết về Việt Nam lúc đó chỉ là những mảnh vụn của các câu chuyện mà Bà Ngoại tôi kể. Nói cách khác, Việt Nam mà tôi biết chỉ hiện hữu trong quá khứ, trong một khoảnh khắc còn đọng lại. Tôi chưa bao giờ nghĩ rằng khi trở về nhà, tôi lại cảm thấy mình là một người di dân một lần nữa - nhưng tôi đã cảm thấy như vậy.

(Nguyên văn Anh ngữ: “...don’t remember anything. I came to America when I was 1.5 years old. I did, however, return to Vietnam for the first time in 2009. It was a terrifying experience because what I knew of Vietnam at the time were remnants of my grandmother's stories. In other words, the Vietnam I knew of existed in the past, in a time warp. I never thought that by going home, I would feel like an immigrant all over againbut I did.”)

Đi tìm nhân diện cá nhân là một quá trình phức tạp, càng phức tạp hơn khi lịch sử gia đình có những điểm liên quan đến định kiến từ dòng chính. Ví dụ, người Mỹ gốc Á phản đối những định kiến mà xã hội Mỹ có về phụ nữ Á Châu (và Việt Nam) như những cô gái lầu xanh, và nhập chung người Châu Á vào giai cấp nông dân. Vương trân quý xuất thân nông dân của gia đình mình và quá khứ của Bà Ngoại mình, như anh nói trong một bài viết trên trang nhà của 
Trangdai Glassey-Tranguyen- Biểu Đạt Căn Tính Di Dân trên Quê Huơng Việt-Mỹ và tại Hải Ngoại

Brooklyn College, "Thật ra, tôi rất hãnh diện về Bà. Không phải dễ để tôi nói điều này. Bà mặc áo tím và làm việc của mình. Và Bà sống sót." Vương không cảm thấy lấn cấn giữa quan điểm của mình và sự công bằng về xã hội và sắc tộc mà người Mỹ gốc Á tranh đấu để đạt tới, bởi vì anh (tác giả chuyển ngữ)

...không thấy việc ủng hộ Bà Ngoại tôi hy sinh cho gia đình là một quan điểm về xã hội và sắc tộc. Sự hãnh diện về gia đình của một cá nhân và quan điểm ý thức xã hội của cá nhân đó là hai điều độc lập. Nói cách khác, tại sao một người không thể vừa phê bình những định kiến về người gốc Á của truyền thông Hoa Kỳ, vừa ủng hộ những ai phải trãi qua một vài chiều kích của những định kiến đó để sống còn? Tôi nghĩ đây là một sự phân biệt quan trọng - đặc biệt là cho những thế hệ người Mỹ gốc Á thế hệ thứ hai và ba, bởi vì họ bị tách rời khỏi kinh nghiệm tang thương trong lịch sử Á Châu từ thập niên 1940 đến 1970, và vì vậy, có đặc quyền phân chia những tang thương thành những vấn đề về xã hội và sắc tộc.

(Nguyên văn Anh ngữ: “...don’t see my supporting my grandmother's sacrifices for her family as a socio-racial stance. Pride in one's family and conscious social stances are independent of one another. In other words, why can't one be critical of the American media's stereotyping Asians while still supporting those who had to embody some aspects of those stereotypes in order to stay alive? I think this is an important distinctionespecially for upcoming second and third generation Asian Americans who, because of their removal from traumatic Asian histories of the 40s throughout the 70s, have the privilege of compartmentalizing trauma as socio-racial tropes.")

Đối với lịch sử gia đình, Vương được tín thác với những câu chuyện quý báu, nhưng chúng sẽ chết theo người kể - không như văn chương. Vì là người duy nhất trong gia đình có khả năng viết lách, anh đã ghi lại những câu chuyện này. Là người bảo quản những câu chuyện này, Vương nhận lấy tránh nhiệm và vinh dự mà không cảm thấy bị áp lực. Khi sáng tác, anh có quyền tạo ra viễn ảnh cho quá khứ (tác giả chuyển ngữ),

Tôi không cảm thấy bị áp lực. Gia đình tôi hoàn toàn mù chữ - cả tiếng Anh lẫn tiếng Việt. Cái mà họ cho tôi trong câu chuyện của họ là một món quà, một di sản. Nhưng, không như của cải hay di sản vật thể, món quà này không thể bị hư hay đánh cắp. Tôi cảm kích cơ hội đưa những câu chuyện này, những cuộc đời này, vào nghệ thuật bằng cách thêm chúng vào trong câu chuyện của chính tôi và sáng tạo của tôi. Tôi không phải là một sử gia. Và, trong ý nghĩa đó, áp lực về mặt chính xác còn rất ít. Tôi điền vào chỗ trống và những khoảng trống bằng những điều tôi tự nghĩ ra.

(Nguyên văn Anh ngữ: "I don't feel the pressure. My family is entirely illiterate-in both English and Vietnamese. What they gave me in their stories was a gift, an inheritance. But, unlike material wealth and relics, it is a gift that cannot break or be stolen. I am grateful for the opportunity to turn these stories, these lives, into art by adding them to my own narratives and inventions. I'm not a historian. And, in that sense, there is less pressure for accuracy. I fill in the gaps and details by making things up.”)

\section{Chuyển hóa Refug-endity}

Là một thi sĩ có thể đồng nghĩa với cảm giác phân cách với gia đình mình, nếu không phải là với 
Trangdai Glassey-Tranguyen- Biểu Đạt Căn Tính Di Dân trên Quê Huoong Việt-Mỹ và tại Hải Ngoại

chính mình và với thế giới xung quanh, lúc này hoặc lúc khác. Nhưng vừa là một thi sĩ và một người khoa bảng trong gia đình có thể làm tăng thêm cảm giác cách biệt này. Quan hệ mật thiết giữa Vương và gia đình và những chăm sóc thực tế mà anh mang dành cho gia đình giúp xoá đi tất cả những cách biệt đó (tác giả chuyển ngữ),

Tôi nghĩ tôi cũng rất may mắn là, không như các phụ huynh Mỹ gốc Á truyền thống vốn muốn con cái họ trở thành bác sĩ hay luật sư, gia đình tôi rất hãnh diện có một người khoa bảng và thi sĩ. Tôi nghĩ vì đối với họ, biết đọc là một quyền lực mà họ chưa bao giờ hiểu hay trãi qua, và vì vậy họ coi nó như một điều đáng được kính ngưỡng và quan trọng thậm chí như phép thuật. Có nhiều lúc tôi đọc tạp chí phổ thông như People hay các báo tạp nhạp khác ở bàn ăn và mọi người từ từ rời khỏi phòng, thì thầm với nhau, "Shhhh. Đi chỗ khác. Ocean đang đọc.” Đối với họ, việc đọc cũng không khác với phép thuật. Ở một cách nào đó, gia đình tôi nói đúng: trong nhà, tôi lo tất cả những việc liên quan đến chữ nghĩa. Tuy sống ở New York City, nhưng tôi lo hết các hoá đơn, những cuộc hẹn khám bệnh, thuế má - tôi còn đi họp phụ huynh cho em trai tôi nữa. Đây là những điều tối thiểu tôi có thể làm cho những hy sinh mà gia đình đã dành cho tôi. Và tôi đã cố nhiều lần dạy Mẹ tôi tiếng Anh - nhưng thật khó trong một gia đình Á Châu để một người con trai hay một người con dạy bất cứ điều gì cho một người lớn. Thứ bậc đóng một vai trò quan trọng trong quan hệ gia đình và việc đổi ngược vai trò thường rất khó khăn, nếu không nói là không thể.

(Nguyên văn Anh ngữ: "I guess I am also fortunate in that, unlike more traditional AsianAmerican parents who want their children to become doctors or lawyers, my family is very proud to have a scholar and poet. I think for them, reading itself is a power they have never understood or experienced, and therefore they see it as something worthy of great reverence and importance-even as surreal. There are times I will be reading People or some other pop-culture trash at the kitchen table and everyone will slowly dissipate from the room, whispering amongst each other, 'Shhhh. Let's go somewhere else. Ocean's reading.' To them, reading is not unlike magic. And in a way, they're right: in our household, I take care of everything regarding words. Even from New York City, I take care of bills, doctors' appointments, taxes - I even go to my younger brother's parent-teacher conferences. It's the least I can do for the sacrifices they have made for me. And I have tried many times to teach my mother English - but it's difficult in an Asian household for a son or a child to teach anything to an adult. The hierarchical roles play a major part in our relationships and such reversals can be very straining, if not impossible.")

Đã trãi qua những hoàn cảnh khó khăn, Vương nhìn sự nghèo khó một cách tương đối. Bởi vì (tác giả chuyển ngữ),

Tôi không bao giờ thấy mình sống trong nghèo đói - tuy tôi nhận ra rằng gia đình tôi nghèo kinh khủng. Thật ra, trong thời gian chúng tôi qua Mỹ, Việt Nam đang phát triển. Nhiều gia đình bắt đầu có TV hoặc radio. Khi mới đến Mỹ, cả nhà chỉ có một căn phòng trống với vài cái mền từ Salvation Army. Tôi đoán sống như vậy là nghèo. Nhưng chúng tôi nhận được trợ cấp xã hội và giúp đỡ từ nhà thờ ở vùng đó, nơi có những buổi phát thực phẩm mỗi Chúa Nhật với cereal hết hạn và bánh mì cũ. Tôi không biết nữa. Tôi nghĩ rằng sự nghèo khổ tương đối dạy cho tôi biết quý những gì tôi có: sự hiện diện của gia 
Trangdai Glassey-Tranguyen- Biểu Đạt Căn Tính Di Dân trên Quê Huơng Việt-Mỹ và tại Hải Ngoại

đình và sức mạnh của những câu chuyện, hình ảnh, và bài hát. Thêm nữa, khi bạn không có gì nhiều, thì bỗng nhiên mọi thứ đều là một quà tặng - một ơn lành thật sự, có thể cảm thấy được. Và tôi thích vậy. Không có gì là chán hết. Bất cứ cái gì cũng là một phụ trội.

(Nguyên văn Anh ngữ: "I never saw myself as living in poverty-although I realize we were terribly poor. In fact, during the time of our immigration, Vietnam was on the rise again. Families began owning TV sets and radios. When we first got to America, we had only a bare room with some blankets from the Salvation Army. I guess you can call that poverty. But we did get help from welfare and the local church, which had food drives that gave out expired cereal and sacks of old bread every Sunday. I don't know. I think that relative poverty taught me what it means to appreciate what I had: the presence of family and the power of stories, images and songs. Also, when you have so little, suddenly every new thing is a gift - a real, felt blessing. And I like that. Nothing is ever boring. Everything is a bonus.")

Vương bắt đầu làm thơ khi Bà Ngoại của anh qua đời. Viết như tang niệm. Viết như cách ghi lại tiếng nói của Bà, để Bà ở lại với anh qua các tác phẩm. Cái chết cũng tương đối, bởi vì (tác giả chuyển ngữ)

Bà Ngoại tôi sẽ luôn luôn là một phần của tôi, cũng như tôi là một sự tổng hợp của các câu chuyện của Bà và của chính tôi. Bà dạy cho tôi rằng những gì tôi học được hay có được trong đời này, tôi đã có rồi - và mỗi lần tôi gặp gỡ với thế giới, bao gồm các công dân của nó, là một sự bùng phát của những kinh nghiệm tiềm ẩn. Nói như vậy, thì Bà Ngoại đã ở trong tôi rồi - ngay cả trước khi Bà mất, Bà đã gieo cấy những mảng của chính Bà trong trí tưởng tượng của tôi. Bà luôn ở với tôi trong mỗi chữ. Nếu có thể làm một điều cho Bà - tôi sẽ tiếp tục làm thi sĩ.

(nguyên văn Anh ngữ: "My grandmother will always be a part of me as I am a composite of her stories as well as my own. She taught me that what I will learn or acquire in my life I will already possess - and that each encounter with the world, including its citizens, is the ignition of dormant experiences. In that sense, my grandmother is already inside me- even before she died she was planting pieces of herself within my imagination. She is with me in every word. If I could do one thing for her - I would keep being a poet.")

Thơ ca có lẽ cách tốt nhất để tưởng thưởng và tưởng nhớ một người mà - từ cách Vương nói về Bà - xem chừng là người có ảnh hưởng lớn nhất đối với anh, vì Bà là người nuôi nấng anh, là Việt Nam của Anh. Nếu Anh có thể viết bằng tiếng Việt, liệu Anh có cảm thấy một cách hoàn toàn khác để ở bên Bà và tưởng nhớ Bà không? Chưa hẳn như vậy. Vương giải thích (tác giả chuyển ngữ),

Không. Tiếng Việt rất quý giá đối với tôi vì nó là ngôn ngữ tôi sử dụng trong bếp, với gia đình. Đó là ngôn ngữ mà tôi học từ những cái chết và sự ra đời của người thân. Qua đó, tiếng Việt hoàn toàn độc lập với nghệ thuật và những gì phức tạp. Khi tôi nói tiếng Việt, tôi nói trong mạch nước trong. Tôi thoải mái nhất. Tôi có thể nói tất cả và không nói gì cùng một lúc. Nên tôi không muốn sáng tác bằng tiếng Việt. Tôi không muốn dùng ngôn ngữ đó cho thơ ca. Tôi không muốn làm hoen ố nó. Hơn nữa, âm nhạc, âm điệu trong tiếng Việt thì đã đủ thơ rồi.

(Nguyên văn Anh ngữ: "The Vietnamese language is precious to me because it is the 
Trangdai Glassey-Tranguyen- Biểu Đạt Căn Tính Di Dân trên Quê Huoong Việt-Mỹ và tại Hải Ngoại

language I use in the kitchen, with my family. It is the language in which I learn of the deaths and births of my kin. In this way, it is free of art and its complexities. When I speak Vietnamese it is speaking in pure water. I am most relaxed. I can say anything and nothing all at once. So I wouldn't want to write in it. I don't want to use that language for poetry. I don't want to taint it. Besides, the music, the intonations in the Vietnamese language are poetic enough.")

Không như một số gia đình Á Châu khó chấp nhận con cái đồng tính, gia đình của Vương đã thông cảm cho chọn lựa giới tính của anh bởi vì, như anh giải thích, gia đình đã sống qua những thăng trầm bỉ cực. Vương kể lại (tác giả chuyển ngữ),

Tôi nói cho Mẹ tôi biết khi tôi mười tám tuổi. Mẹ tôi nói, "Vậy là từ nay, con sẽ mặc đầm hả?" Mẹ tôi có lo lắng ban đầu, nhưng đã nhanh chóng chấp nhận. Thật ra, chính điều này đã làm chúng tôi gần gũi nhau hơn. Như chị thấy, gia đình tôi đã mất mát quá nhiều không chỉ trong chiến tranh, mà còn qua những chật vật ở Mỹ. Chúng tôi sống như không biết ngày mai. Và, dĩ nhiên là vì những lý do chính đáng. Đối với nhiều thành viên trong gia đình tôi, đã có nhiều lúc, ngày mai đã thật sự không bao giờ đến. Không giống như những anh chị em đồng tính gốc Á khác, đối với tôi, những khó khăn khi tuyên bố giới tính của tôi thì rất nhỏ so với những kinh hoàng mà gia đình tôi đã trãi qua - như bom đạn và trại cải tạo. Chúng tôi sống như thể chúng tôi không nên có được một cơ hội thứ hai, nên hiếm khi chúng tôi có định kiến. Có lẽ vì vậy mà phần lớn gia đình tôi đều bị phá sản. Giống như Bà Ngoại hay nói, "Chơi xả láng, sáng về sớm!"

(Nguyên văn Anh ngữ: "I told my mother when I was 18. She just said: 'Does this mean you going to start wearing dresses?' She was concerned at first but she accepted it fairly quickly. In fact, it made us closer. You see, my family lost so much — not only in the war, but also during our struggles in the states. We have a very live-like-there's-no-tomorrow mentality. And, well, for good reason of course. For most members of my family, there has been, indeed, moments when tomorrow might have never come. Unlike many of my queer American brothers and sisters, for me, the difficulties of coming out were minimal compared to other traumas my family experienced-like bombs \& concentration camps. We have lived as if we shouldn't have been given a second chance, so it's hard to hold many reservations. Maybe this is why most of my family is also bankrupt. Like my grandmother used to say: 'Chơi xả láng, sáng về sớm!'”)

Nhưng Vương có một tâm hồn chiêm niệm và là một Phật tử thuần thành. Đời sống tâm linh đã ảnh hưởng và định hướng cõi thơ của anh: cả trong quá trình viết, lẫn trong nhân sinh quan. Như Vương nói (tác giả chuyển ngữ),

Đối với Phật tử, căn cội của tất cả khổ ải chính là dục vọng. Tôi chấp nhận sự thật là tôi không phải là một tu sĩ, và đời sống của tôi cũng thường bị sai khiến bởi ngay cả những dục vọng căn bản nhất: công việc, căn nhà cho Mẹ tôi, quyển sách mới ấn hành của một tác giả nào đó, cơ thể một người đàn ông, những không gian tĩnh lặng và rộng mở. Tuy nhiên, điều mà tôi thấy hầu như không thể chấp nhận được, là vừa làm Phật tử vừa làm thi sĩ. Vâng, những thi sĩ Phật giáo khác như Jan Hirshfield và Gary Snyder, cả hai thi nhân mà tôi ngưỡng mộ, đã làm được. Nhưng đối với tôi, nội sự ham muốn sáng tác thơ của tôi cũng là vấn đề. Ngay trong khi tôi viết những điều này, hằng trăm tu sĩ Phật giáo 
Trangdai Glassey-Tranguyen- Biểu Đạt Căn Tính Di Dân trên Quê Huơng Việt-Mỹ và tại Hải Ngoại

ở Tây Tạng đang bị đánh đập, giết chết, và đàn áp bởi chính quyền Trung Quốc. Bài thơ của tôi sẽ làm gì cho họ? Thật khó để tôi đối diện với chữ nghĩa của chính mình khi cả thế giới đang sôi động, còn tôi, tôi đang loay hoay với một mớ giấy mực.

(Nguyên văn Anh ngữ: For Buddhists, the root of all suffering is desire itself. I accept the fact that I'm not a monk, that my life is too often dictated by even the most basic desires: a job, a house for my mother, so and so's new book, a man's body, quiet, open spaces. What I find nearly impossible to accept, however, is being both a Buddhist and a poet at the same time. Yes, other Buddhist poets like Jane Hirshfield and Gary Snyder, both of whose work I admire, have pulled it off. But for me, what's most problematic is the very desire to make poems at all. As I write this, hundreds of monks in Tibet are being beaten, killed, and persecuted by the Chinese government. How can my poem make a difference there? It's hard to come to terms with my writing when the world is on fire and here I am, obsessing over a handful of paper.”)

\section{Vương suy tư thêm (tác giả chuyển ngữ),}

Như chính cơ thể mà tôi có đây, hành động viết, đối với tôi, chỉ là một phương cách dịch thuật, một nơi để giữ linh hồn. Hơn nữa, tôi phải đối diện với sự thật rằng bài thơ của tôi sẽ không bao giờ là cái mà tôi dự tính - tôi chỉ có thể đến thật gần điều mình muốn viết (nếu tôi may mắn). Tôi phải chấp nhận sự thật rằng chính những chữ nghĩa mà tôi nhào nặn cuối cùng cũng sẽ làm tôi thất bại. Jack Gilbert có lẽ nói điều này thấm thía hơn cả, "Tình yêu, chúng ta nói, Thượng đế, chúng ta nói, Rome và Michiko, chúng ta viết, và ngôn từ vẫn hiểu sai chúng ta." Vậy đó, ngôn từ hiểu sai chúng ta, và dù vậy, chúng ta vẫn thức dậy, chúng ta cố yêu nhau, cố chống chọi với khả năng hành xử tàn ác của mình, và chúng ta thử, chúng ta sáng tạo, và chúng ta đào bới ngôn ngữ cho đến khi chúng ta thoả mãn nhu cầu tạo ra một cái gì đó có ý nghĩa. Nhưng việc cố gắng là điều tôi sợ. Tôi cầm bút lên và nghĩ, "Liệu tôi có thể làm điều gì tốt hơn với đôi tay này không?" Khi tôi sửa những khuyết điểm trong bài thơ, những khuyết điểm của một nam nhân chồng chất quanh tôi, thường là không được chú ý đến. Điều này làm cho tôi sợ hơn bất cứ điều gì: ý nghĩ là tôi sẽ dùng hết thời gian quý báo trên đời để viết những bài thơ ít người đọc đến, trong khi có quá nhiều điều tôi có thể làm với cơ thể mà tôi đã được ban cho.

(Nguyên văn Anh ngữ: "Like this very body I possess, the act of writing is, to me, just a means of translation, a place to store the soul. What's more is that I have to face the fact that the poem will never be what I intended it to be-I can only get very close (if I'm lucky). I have to accept the fact that the very material I work with will ultimately fail me. Jack Gilbert perhaps said it most poignantly: 'Love, we say, God, we say, Rome and Michiko, we write, and the words get it wrong.' They do, they get it wrong, and still we get up, we try to love each other, to resist our incredible ability to be cruel, and we try, we work and we mine language until it satisfies our need to make something meaningful. But the trying is what I fear. I pick up the pen and think: 'Could I be doing something better with these hands?' As I fix the flaws of the poem, the flaws of a man stack up around me, often times unnoticed. This scares me more than anything: the idea that I will end up using this precious time on earth making poems very few people will read, while there is still so much I can do with this body I am given.") 
Trangdai Glassey-Tranguyen- Biểu Đạt Căn Tính Di Dân trên Quê Huoong Việt-Mỹ và tại Hải Ngoại

\section{"A Hapa Rap in Vietnamese"}

Trong phần thảo luận về các văn nghệ sĩ ngoại biên gốc Việt, tôi muốn kết thúc với lòng kính trọng đối với cố thi sĩ John Vietnam Nguyễn, một người đã sống với tôn chỉ cả đời là "Hãy nhớ gốc gác của bạn" (tôi dịch từ cụm từ: Know your roots). Cả Ocean Vương và John Vietnam Nguyễn vật lộn với nhân diện gốc Việt của mình, nhưng trong những cách khác biệt. Tuy sinh ở Mỹ, Nguyễn sử dụng tiếng mẹ đẻ trong sáng tạo, trong khi Vương kính ngưỡng tiếng Việt và không muốn "làm hoen ố nó." Nguyễn về nguồn, tưởng niệm biến cố Sài Gòn thất thủ và lăn lộn trong di sản sắc tộc của mình. Về kết thúc của cuộc chiến Việt Nam ${ }^{\text {xxxvi }}$, Nguyễn viết (tác giả chuyển ngữ),

30 tháng Tư, còn gọi là Tháng Tư Đen, tượng trưng cho ngày miền Nam thất thủ và kết thúc chiến tranh Việt Nam. Hôm nay, chúng ta tưởng niệm những ai đã rời bỏ, đã chiến đấu, và đã sống qua cuộc chiến bằng cách mặc màu đen và viết chữ "Saigon" hay "Sài Gòn” trên bàn tay, cổ tay, hay cánh tay chúng ta. Đối với tôi, đây là cách truy nhận gốc gác, và một cách tỏ lòng tôn kính đúng nơi đúng lúc.

(Nguyên văn Anh ngữ: "April 30th, also known as Black April, symbolizes the Fall of Saigon and the end of the Vietnam War. Today we commemorate those who fled from, fought for, and lived through the war by wearing black as well as writing 'Saigon' or 'Sài Gòn' on our hands, wrists, and arms. For me, it is an acknowledgment of my roots, and a way to pay my respects where they are due.")

Cõi âm-thanh và không-gian mang tên John Vietnam Nguyễn gợi lên một cảm giác 'mái ấm’ cho một nghệ sĩ nhạc ráp gốc Việt sinh tại Mỹ, được anh quy tóm trong dòng chữ ký song ngữ, "One life, one love-Một đời, một tình yêu." Mặc dù anh ra đi bất ngờ khi còn rất trẻ vì chết đuối sau khi cứu một người bạn trong lúc đi bơi tại hồ Mendota ở Madison ${ }^{\text {xxxvii }}$, Nguyễn để lại một di sản lâu dài đối với cộng đồng của anh tại nhà, ở trường, và trong nghệ thuật. Cộng

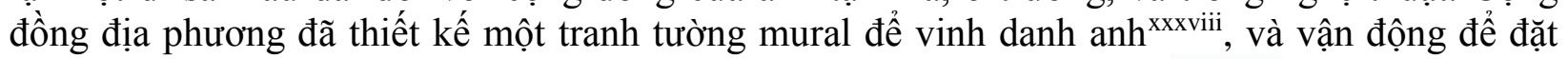
tên anh cho một con đường trong xóm (Emmanuel, 2014; Schmich, 2014). Trong một thư khuyến khích bạn bè, anh bày tỏ niềm tin mãnh liệt rằng (tác giả chuyển ngữ):

Hip-hop không chỉ là chuyện làm cho có, mà là một lối sống. Emceeing, hay là rapping, không phải là một sở thích. Giá trị sâu xa trong hip-hop hiện rõ trong hành động và thái độ của bạn bên ngoài một vòng cypher hay một bài hát (chú thích của tác giả: cypher, trong nhạc rap, là hát liên tiếp theo vòng; một người hát kiểu freestyling sẽ rap theo kiểu cypher, hết khúc này đến khúc khác; người hát rap phải biết lúc nào đến phiên mình và không cắt ngang một cypher). Tất cả là về hoà bình, tình yêu, tình liên đới, và cùng vui với nhau. Emceeing là cách để đối diện với những vấn đề trong cuộc sống; nghệ thuật là kết quả của đau khổ. Cuối cùng khi đã có đủ luyện tập và cảm hứng, nghệ thuật của bạn sẽ trở thành một điều người khác có thể cảm thông, bởi vì mọi người chúng ta đều trãi qua những vấn đề tương tự. Bạn học cách trở thành người lãnh đạo, không phải chỉ trong lúc bạn spitting, nhưng khi những giây phút quyết định xảy đến trong đời sống và bạn phải bước tới. Một emcee không chỉ spit. Mà còn phải có văn hoá hip-hop nằm sâu trong gene của mình. Một emcee không chỉ ngồi thừ và làm ngơ vấn đề. Hãy đối đầu với nó. Những emcees nên nhìn vào số điểm như là cypher. Bắt tay vào. Làm việc của bạn theo cách cần. Và khi xong biết rằng mình đã làm đúng. 
Trangdai Glassey-Tranguyen- Biểu Đạt Căn Tính Di Dân trên Quê Huơng Việt-Mỹ và tại Hải Ngoại

(Nguyên văn Anh ngữ: "Hip-hop isn't just something do, it's the way you live. Emceeing, or, rapping, isn't just a hobby. The values ingrained in hip-hop emerge in your behavior and attitude outside of the cypher or song. It's all about peace, love, unity, and having fun. Emceeing is a way to cope with problems in life; art is a result of suffering. Eventually with enough practice and inspiration, your art becomes something people relate to, because we all go through the same problems. You learn how to be a leader, not just when you're spitting, but when those crucial moments arise in life where you just need to step up. An emcee doesn't just spit. He has the hip-hop culture embedded in his genes. An emcee wouldn't sit back and ignore the problem. Tackle it directly. Emcees should look at grades like the cypher. Get in there. Do your thing the way it should be done. And come out knowing you did it right.")

Nguyễn tin tưởng mạnh mẽ vào tiềm năng của mỗi cá nhân, và những câu chuyện duy nhất trong mỗi chúng ta. Anh viết (tác giả chuyển ngữ),

Nếu bạn muốn trình diễn trôi chảy, bạn phải tập đi tập lại. Chịu khó dợt lời. Viết những cụm từ đa âm cùng vần để tập. Học từ mới mỗi ngày. Trình diễn theo kiểu tự do mỗi ngày. Đặt cho mình tiêu chuẩn cao trong MỌI VIỆC bạn làm. Đừng bao giờ chấp nhận những gì chưa hoàn thiện. Nếu nhịp chảy của bạn đứt quãng, đừng coi đó là một tác phẩm đã hoàn tất. Hãy chuẩn bị công cụ sẵn sàng trong mọi lúc. Nếu bạn nghiêm túc về việc thu âm, hãy tìm hiểu về những khâu kỹ thuật của nó. Đừng xin trò chơi điện tử vào dịp Giáng Sinh hay sinh nhật của bạn. Hãy xin một cái condenser microphone (chú thích của tác giả: đây là loại microphone sử dụng pin hay điện, nhưng có cục biến thế để chuyển sóng âm thành sóng điện). Hãy tự thúc đẩy mình mạnh mẽ hơn bạn bè của bạn tự thúc đẩy họ. Hãy là nguồn cảm hứng cho họ. Hãy hiểu rằng phải chịu khó thì mới đi đến thành công. Nếu bạn có động lực từ bên trong và hoài bão để thành công, không có gì có thể cản trở bạn, và ánh sáng của bạn cuối cùng sẽ toả sáng - và để được như vậy, thì cần kiên nhẫn. Dù gì đi nữa, những công khó khởi đi từ tâm hồn thì luôn được nhìn thấy. Hãy tiếp tục làm việc của bạn. Và kể chuyện của bạn. Không mánh lới.

(Nguyên văn Anh ngữ: "If you're serious about your flow, you have to practice. Do lyrical exercises. Write multi-syllabic rhyme schemes for practice. Learn new words everyday. Freestyle everyday. Set a high standard for EVERYTHING you do. Never settle for less than perfect. If your flow is off, don't call it a finished work. Have an arsenal ready. at all times. If you're serious about recording. learn about the technical aspects of it. Don't ask for video games for Christmas or your birthday. Ask for a condenser microphone. Be more motivated than your peers. Be their inspiration. Understand that hard work is the road only known for success. If you have the inner drive and desire to be successful, then nothing will hold you back, and your light will eventually shine - this is where patience comes in. Regardless, hard work that comes straight from the soul is always recognized. Keep doing you. And tell your story. No gimmicks.")

Không mánh lới. Đó là cách Nguyễn sống trọn đời sống ngắn ngủi của mình. Tôi cho rằng chiêu tuyệt nhất của anh chính là bài "A Hapa Rap in Vietnamese," được trình diễn bằng tiếng Việt với phụ đề song ngữ. Đây là lời tiếng Việt tôi đã đánh máy từ Youtube video ${ }^{\text {xxxix. }}$ 
Trangdai Glassey-Tranguyen- Biểu Đạt Căn Tính Di Dân trên Quê Huơng Việt-Mỹ và tại Hải Ngoại

thành phố Chicago 773

nghe thử

cái gì mình đi lên

cũng phải đi xuống

không bao giờ mình có

những gì mình muốn

chúng ta biết hạnh phúc ở đâu mà kiếm

trên đời này người tốt là hiếm

người ta nói nhiều chuyện

muốn mình nghề có lương cao

bài hát này là của mình

người ta nghĩ là tự cao

nghe rõ

mấy câu tôi nói vì dễ nhớ

đây là câu chuyện giữa một người Việt và một người Mỹ đó

tôi nghĩ

cuộc đời khi đẹp khi xấu đó

sao thù hận nhau chúng ta cùng dòng máu đỏ

nô lệ của xã hội

chúng ta chưa có tự do

mọi người bị đói kiến thức

mọi người chưa được ăn no

mời các bạn

nghe thử lời này

không có gì dễ ở trên đời này

người ta hỏi hoài

tôi sống ở đâu

("where're you from?")

mà nếu mà biết đi ở đâu trước

đừng hỏi gì hết

đừng nói gì hết

khi tôi không nói gì hết

là tôi đã chết

\section{Những Mùa Refug-endity Song Ngữ Mới}

Ở đây, tôi chọn không thảo luận khả năng tiếng Việt của Nguyễn, nhưng chú trọng vào việc anh kết hợp một cách mới mẻ tiếng mẹ đẻ và điệu nhạc rap. Sự táo bạo trong việc Nguyễn sử dụng tiếng Việt trong nhạc rap của mình cho chúng ta lý do để tin vào vai trò quan trọng mà tiếng Việt tiếp tục có trên đời sống và nghệ thuật của thế hệ gốc Việt ngoại biên. Với những chương trình song ngữ Anh-Việt đang phát triển trong giáo dục công lập ở mọi cấp từ Mẫu Giáo (GlasseyTranguyen, $2014 \mathrm{~g}$ ) đến đại học (Glassey-Tranguyen, 2013d), rất có thể trong tương lai, chúng ta sẽ có nhiều tác giả và nghệ sĩ song ngữ hơn, những người có thể luân chuyển giữa hai thế giới ngôn ngữ Anh và Việt một cách thoải mái, tự hào, và lưu loát. Những biểu đạt và thể hiện về di- 
Trangdai Glassey-Tranguyen- Biểu Đạt Căn Tính Di Dân trên Quê Huoong Việt-Mỹ và tại Hải Ngoại

dân-tính refug-endity của người Việt hải ngoại sẽ chắc chắn không chỉ trong các ngôn ngữ khác mà bằng cả tiếng Việt.

Nhờ đó, những mùa nghệ thuật hải ngoại mới đang trở nên càng toàn cầu hơn, và những tài năng sáng tạo song ngữ của tương lai sẽ không chỉ được tưởng thưởng tại hải ngoại và quanh thế giới, mà còn được trân quý tại đất nước Việt Nam. Tôi đã kết luận ở một số bài viết khác (Glassey-Tranguyen, 2015) rằng vì những tương tác và ảnh hưởng qua lại giữa Việt Nam và cộng đồng Việt hải ngoại, Việt Nam có tính hải ngoại và hải ngoại cũng cưu mang Việt Nam. Là một trung gian không biên giới, nghệ thuật sáng tạo có thể nối kết Việt Nam với hải ngoại cách thiết thực hơn và ngược lại. Nghệ thuật sáng tạo cũng gặp gỡ với những cộng đồng không phải gốc Việt xuyên qua các khoảng cách địa lý và thai nghén những nhân diện và đối thoại mới. Nghệ sĩ gốc Việt cũng như khán giả của họ tại hải ngoại có thể tiếp tục gắn bó với cội nguồn và có cảm hứng để đi tìm nhân diện của mình - một sự tiếp tục chắc chắn hướng đến những mùa sáng tạo mới của di-dân-tính refug-endity. Qua những công việc này, những thế hệ ngoại biên gốc Việt có thể ghi lại và biến đổi quá khứ qua việc hồi tưởng và/hoặc với chính suy tưởng mới của mình như trường hợp của Ocean Vương. Ở năm 2015, chúng ta có cái đặc quyền hiếm hoi là nhìn lại bốn mươi năm định hình cộng đồng Việt hải ngoại và sáng tạo nghệ thuật, từ những tác phẩm sáng tạo đầu tiên được xuất bản bằng tiếng Việt tại Quận Cam của 1975 đến những sáng tác mới nhất vừa ló dạng tại hải ngoại hôm nay. Những thế hệ của văn nghệ sĩ gốc Việt đã đáp lại tiếng gọi sáng tạo và tận hiến cho việc ghi lại kinh nghiệm của mình qua nghệ thuật, và qua đó, giúp tiếp tục những biểu hiện, tìm kiếm, và xiển dương kinh nghiệm của người Việt hải ngoại - một di sản được trao truyền lại cho các thế hệ tương lai để giúp họ gắn bó với nguồn gốc.

\footnotetext{
${ }^{\mathrm{i}}$ Tôi xin cám ơn các vị thẩm định (reviewers) của JSAEAA đã đưa ra những nhận xét quý báu về phiên bản đầu tiên của bài viết này; xin cám ơn Chủ bút của JSAEAA Tiến sĩ Wayne Wright, Tổng thư ký Marshall Klassen, và Nhà thơ Bryan Thao Worra; và Olivier Glassey-Trầnguyễn đã đọc và góp ý cho bản tiếng Anh. Tôi chân thành cảm ơn anh Marshall Klassen đã hỗ trợ tôi trong việc giữ nguyên tên các tác giả Việt Nam, và liệt kê các tài liệu tham khảo theo kiểu APA.

${ }^{i i}$ Xin xem Tranguyen, 2004b. Tham khảo thêm những tài liệu và chương trình do Poets in VietnAmerica thực hiện từ thập niên 1990s đến nay.

iii Chắc chắn có nhiều đối lập và cạnh tranh trong giới cầm bút người Mỹ gốc Việt, cũng như trong bất cứ môi trường chữ nghĩa nào. Vì bài viết chú trọng vào tính tự phát tự lực, tôi sẽ bàn đến những tranh chấp và căng thẳng trong một bài khác.

iv Ở đây, tôi chú trọng đến những sáng tác có 'liên quan' hơn là 'quan trọng' vì hai lý do. Thứ nhất, vẫn chưa có một cuộc nghiên cứu rốt ráo về văn chương tiếng Việt tại hải ngoại từ năm 1975 , nên tôi xin giữ cho rộng đường dư luận việc đánh giá tác phẩm nào là 'quan trọng.' Thứ hai, bài viết của tôi không phải là một thống kê về các tác phẩm này, nhưng tập trung vào việc nhận định xem những tác phẩm này đã giúp định nghĩa refug-endity trên quê hương Việt-Mỹ và cộng đồng hải ngoại như thế nào.

v Ngay khi tôi bắt đầu sử dụng phương pháp lịch sử truyền khẩu từ thập niên 1990s, tôi đã ý thức và chọn thực hiện phỏng vấn theo hình thức chiều sâu đi dọc theo tiểu sử của người nói thay vì chỉ phỏng vấn theo một đề tài cách rút gọn. Tuy chọn lựa này đòi hỏi nhiều thời gian và công sức hơn, nó cho phép tôi đi vào những chứng từ sâu sắc và đặt những câu hỏi để đào sâu những uẩn khúc và khúc quanh trong câu chuyện. Tôi nhận thấy phỏng vấn dạng tiểu sử không chỉ hữu dụng, mà còn mang tính quyết định trong việc giúp tôi bàn đến những chi tiết sâu kín khi thời gian phỏng vấn có giới hạn.

vi Văn khố Đông Nam Á tại Đại học Cornell - Tài liệu của chính phủ Hoa Kỳ về người tỵ nạn năm1968.

vii Trong quyển bút ký này, vốn đoạt giải Quốc Gia của Việt Nam Cộng Hoà năm 1969, Nhà văn Nhã Ca ghi lại kinh nghiệm của mình ngay trên đất Huế khi Việt Cộng tấn công cố đô vào dịp Tết Mậu Thân 1968. Quyển sách được Nhật báo Việt Báo tái bản năm 2008, và bản tiếng Anh của Olga Dror được Nxb Indiana University Press phát hành năm 2014.

viii Tham khảo tác phẩm trên trang Talawas: http://www.talawas.org/talaDB/showFile.php?res=10521\&rb=08.
} 
ix Tham khảo tác phẩm trên trang Talawas: http://www.talawas.org/talaDB/showFile.php?res=10521\&rb=08.

x Trong một số tài liệu học thuật, có sự phân biệt giữa hai từ 'người tỵ nạn' và 'người di dân' trong lịch sử di dân của người Việt từ 30 tháng Tư, 1975. Đối với những người tản cư trong khoảng thời gian ngay trước và ngay sau 30 tháng Tư, 1975, cũng như các thuyền nhau từ ngay sau đó đến đầu thập niên 1990s, cụm từ 'người tỵ nạn' thường được dùng với hàm ý chính danh và xứng đáng, cũng như kèm theo tầm quan trọng lịch sử và chính trị hơn là cụm từ 'người di dân.' Đối với những làn sóng người đến sau - những người theo diện đoàn tụ gia đình, hay cựu tù nhân chính trị đi theo diện $\mathrm{HO}$ - họ thường được gọi là 'người di dân,' với tính chính đáng thấp hơn. Ngoài ra, còn có du sinh từ Việt Nam, thương nhân, văn nghệ sĩ và các chuyên gia khác, định cư theo diện hôn nhân, vV... Sự phân biệt này thất bại vì không đưa ra được sự phức tạp trong các quá trình di dân, và che đậy một sự thật là ngay cả sau khi chiến tranh đã kết thúc một thời gian dài, vẫn có 'người tỵ nạn' bị đàn áp ngay trên chính quể hương của họ, như những người tù chính trị. Ở đây, tôi sử dụng hai từ này trong ý thức là chúng đi ngược lại những mấu chốt về lịch sử và bối cảnh di dân từ Việt Nam, và trong ý thức đi ngược lại sự phân đôi tuỳ tiện từng đi kèm với hai từ này.

xi Tôi đã lập luận trong một số bài viết là Việt Nam là một phần của cộng đồng hải ngoại và ngược lại. Xin xem Glassey-Tranguyen, 2015.

xii Để biết thêm về Dự án VAP, xin xem Tranguyen, 2004b. Một phiên bản của bài nghiên cứu này đoạt giải thưởng của cuộc tranh tài nghiên cứu tại Đại học Cal State Fullerton năm 2013, và đoạt giải quán quân tại cuộc tranh tài nghiên cứu hằng năm lần thứ 18 của hệ thống Đại học CSU năm 2003-04 trong ngành Nhân Văn và Văn Chương, trình độ hậu đại học.

xiii Tuy có một số người trên quê hương Việt-Mỹ VietnAmerica phản đối Trịnh Công Sơn là tay sai Cộng Sản và không chấp nhận dòng nhạc Trịnh, những bài hát của ông vẫn rất phổ biến trong nhiều thế hệ từ thời chiến tranh Việt Nam.

xiv Cố nhạc sĩ Nguyễn Đức Quang là sáng lập viên của Nhật báo Viễn Đông, một trong các tờ nhật báo Việt ngữ chính tại Quận Cam. Sinh ngày 11 tháng Hai, 1944, tại Sơn Tây, Bắc Việt, Nguyễn Đức Quang di cư vào Nam với gia đình năm 1954 khi Hiệp định Geneve chia đôi đất nước. Một nhân tài âm nhạc, ông được biết đến và yêu thích ở cả Việt Nam lẫn hải ngoại. Những bài hát của ông chạm đến những nẻo hồn thăm thẳm của con người, đặc biệt là đồng bào Việt Nam qua nhiều thể hệ và không gian. Ổng phục vụ trong Quân đội miền Nam Việt Nam Cộng Hòa trước năm 1975, chịu nhiều năm tù cải tạo, vượt biển, và định cư tại Mỹ. Tiểu sử song ngữ do Glassey-Trầnguyễn soạn và in trong quyển chương trình song ngữ "Vết Thuoong Vô Diẹn, Hòa Bình Vô Danh - Faceless Wounds, Nameless Peace."

xv Trần Mộng Tú là một thi sĩ, văn sĩ, và từng là Chủ bút của Nguyện san Phụ Nữ Gia Đình, một phó bản của Nhật báo Người Việt. Một cộng tác viên thường xuyên cho các tạp chí văn học toàn cầu từ năm 1975, Trần Mộng Tú đã xuất bản nhiều tác phẩm thơ văn, tiêu biểu như "Thơ Trần Mộng Tú" (Người Việt, 1990), "Câu Chuyện của Lá Phong" (Thế Kỷ, 1994), "Để em làm gió" (Thế Kỷ, 1996), và "Cô Rơm và Những Truyện Ngắn” (Văn Nghệ, 1999). Bà có thơ đăng trong tuyển tập Dream of Peace (Warner Books, 1990), Anthology of Vietnamese Poems from the Eleventh through the Twentieth Centuries (Yale University Press, 1996), và American Literature textbook (Glencoe/McGraw-Hill, 1999). Tiểu sử song ngữ do Glassey-Trầnguyễn soạn và in trong quyển chương trình song ngữ "Vết Thưong Vô Diện, Hòa Bình Vô Danh - Faceless Wounds, Nameless Peace."

xvi Tôi có được nhận định này qua hai thập niên sống ở Việt Nam sau 1975 và hai thập niên sinh sống và nghiên cứu trong cộng đồng Việt Nam hải ngoại tại bốn châu lục.

xvii Tôi gọi việc tiếng Việt bị làm nhục khi miền Bắc chiếm miền Nam là 'sát nhân' vì nó nhắm vào việc xoá bỏ không chỉ ngôn ngữ đang được sử dụng ở miền Nam trước cuộc cưỡng chiếm, mà còn để thủ tiêu bất cứ tầng lớp trí thức và văn hoá nào tại miền Nam trước đó. Tuy chính quyền mới không tuyên bố một cuộc cải cách ngôn ngữ như trong trường hợp cải cách ruộng đất, cải cách giáo dục, cải cách kinh tế, vv - nhưng sự đô hộ của chính quyền miền Bắc đi tới việc xoá bỏ tất cả những gì đã có ở miền Nam trước khi bị họ xâm chiếm.

xviii Tôi đưa ra nhận xét này với một ý thức trọn vẹn về con đường trơn trợt của ký ức và sự phức tạp trong việc gợi lại những biến cố trong quá khứ. Xin xem Tranguyen 2004b và 2000b. Cũng xin xem thêm phần sau của bài này.

xix Có thể đọc toàn bộ tác phẩm Đại Học Máu trên Thư viện Sáng Tạo: http://sangtao.org/2013/05/30/dai-hoc-mauvao-truyen/.

${ }^{x x}$ Có nhiều cố gắng để ghi lại kinh nghiệm thuyền nhân Việt Nam, như Project Ngọc tại UCI, Văn Khố Thuyền Nhân tại Úc, các văn khố Đông Nam Á tại Đại học Cornell, và các nơi khác.

xxi Tượng đài thuyền nhân Việt Nam ở các nơi như Canada và Úc Châu, cũng như các tượng đài tri ân những quốc gia đã cưu mang người Việt tỵ nạn như ở Hamburg, Đức quốc, đã được xây dựng trong các năm qua với những chương trình tưởng niệm chiều kích này của di-dân-tính Việt refug-endity trên toàn thế giới.

xxii Ở đây, tôi dùng chữ 'thấu hiểu' trong cả hai nghĩa: 'thông hiểu' và ‘đưa đến sự hiểu biết mới.' 
Trangdai Glassey-Tranguyen- Biểu Đạt Căn Tính Di Dân trên Quê Huơng Việt-Mỹ và tại Hải Ngoại

xxiii Tôi đặt chữ 'truyền thống' trong ngoặc kép với ngụ ý không có văn hoá nào tồn tại trong cô lập, nên càng không thể nào truy nhận một sự thuần tuý hoàn toàn trong văn hoá Việt Nam, một đất nước vốn mệnh danh là 'bao lơn của Biển Thái Bình,' luôn luôn tương tác với những thế lực ngoài Việt Nam ngay từ những ngày đầu lập quốc. Do đó, ngay cả những gì được coi là 'truyền thống Việt Nam' hôm nay cũng rất có thể là kết quả của kết hợp văn hoá, như chiếc áo dài Việt Nam vốn có nguồn gốc từ văn hoá Chăm.

xxiv Xin xem http://www.vietnamesemusic.us/.

xxv Tuy Underhill thuộc thế hệ ngoại biên, tôi tin rằng phần thảo luận về tác phẩm của cô thích hợp với đề tài giữ gìn văn hoá và tự lập sắc tộc trong phần này hơn. Trong nhiều cách, Underhill là một người rất tự lập và trong cộng đồng Việt hải ngoại, cô luôn dùng tiếng nói của mình - một người sắc tộc Chăm - để tranh đấu cho quyền được công nhận và quyền công dân của người bản xứ (indigenous) và thiểu số ở trong cũng như ngoài Việt Nam.

xxvi Nhiều tác giả khác có tác phẩm liên quan đến đề tài refug-endity, nhưng trong khuôn khổ của bài viết, tôi không thể phân tích ở đây. Thí dụ, Monkey Bridge (1997 Viking Penguin) và The Lotus and the Storm (2014 Viking Press) của Lan Cao; The Gangster We're All Looking For (Knopf, 2003) của lê thị diễm thuý; Book Of Salt (2003 First Mariner books) và Bitter In The Mouth (2010 Random House) của Monique Trương; Ru (2012 Random House Canada) của Kim Thúy; etc.

xxvii Howard Vũ mời tôi giúp coi lại và hiệu đính kịch bản song ngữ của phim, và sau đó mời tôi tham gia trong tư cách người tuyển diễn viên, chuyên viên huấn luyện ngôn ngữ, và thông dịch viên lúc quay phim. Tôi đã có mặt trong suốt quá trình làm phim để nâng đỡ, cố vấn, và góp ý.

xxviii Xin xem thêm Glassey-Tranguyen \& Đào 2011, Glassey-Tranguyen 2011b, \& 2012e, \& 2012f về những vết tích của chiến tranh trong cách Thắng Đào kết hợp nhạc Việt và vũ điệu ballet.

xxix Bình Danh. Dự án: "Immortality, The Remnants of the Vietnam and American War." binhdanh.com.

xxx Danh Võ. "Go Mo Ni Ma Da,” 24 tháng Năm đến 18 tháng Tám, 2013. Musée D'Art Moderne de La Ville de Paris. http://www.mam.paris.fr/en/expositions/danh-vo.

xxxi Vuợt Sóng đoạt nhiểu giải thưởng, trong đó có giải Best Cinematography tại Liên hoan phim quốc tế ở Milano, giải Best Feature Film tại Liên hoan phim quốc tế Anchorage, giải Grand Jury Prize tại Liên hoan phim quốc tế Amazonas ở Brazil, và nhiều giải khác.

xxxii Các phim khác của Đạo diễn Hàm Trần gồm có: Ngày Giỗ/The Anniversary (2004), Pomegranate (2002), Parents (2002), The Prescription (2001), Poetree (2000), và Sisyphus (2000).

xxxiii Ông bà nội ruột của Hàm Trần di dân từ Triều Châu, Trung Quốc, qua Việt Nam trước Đệ nhị thế chiến. Bà nội ruột của anh qua đời khi cha anh mới 16 tuổi. Ông nội của anh sau này cưới một phụ nữ Việt Nam tại Vĩnh Long. Bà nội kế, nhưng lại là bà nội thật sự, là người có ảnh hưởng lớn nhất về văn hoá Việt Nam đối với Trần.

xxxiv Xin xem Việt Hồ Lê, "The Death of Marat," silver print.

xxxv Xin xem Việt Hồ Lê, "The Death of Marat," silver print.

xxxvi Tôi vẫn cho rằng cuộc chiến Việt Nam vẫn còn đang diễn ra trong nhiều cách, dù các tranh chấp vũ trang đã chính thức kết thúc vào tháng Tư 1975. Xin xem Glassey-Tranguyen, 2008.

xxxvii Richardson 2012. Bản tin không nói về việc Nguyễn chết đuối sau khi cứu một người bạn, nhưng bạn bè có mặt đã làm chứng cho hành động cao cả này của anh.

xxxviii John Vietnam Nguyen's Memorial Mural x Heaven: http://www.youtube.com/watch?v=ngYhkh4n5pk.

xxxix https://www.youtube.com/watch?v=V3U-hqQ3kGo. Accessed 6/30/2014. 
Trangdai Glassey-Tranguyen- Biểu Đạt Căn Tính Di Dân trên Quê Huoong Việt-Mỹ và tại Hải Ngoại

\section{Ghi chú}

Tên tất cả các tác giả đều được ghi theo phương pháp trích dẫn của APA (Họ, và chữ đầu của Tên; ví dụ, Nguyễn, A.), chỉ trừ tên những tác giả có dấu sao *. Tôi giữ tên những tác giả này theo đúng thứ tự tiếng Việt để giúp người đọc nhận diện được tác giả, và để tỏ lòng tôn trọng đối với tác giả. Trong văn chương tiếng Việt, bút danh có thể do tác giả tự tạo ra, như Hàn Mạc Tử; hoặc đặt theo quê quán của tác giả, như Đông Bàn; hoặc một tên chiết từ tên thật của tác giả, như Vũ Ánh (từ Vũ Văn Ánh); hoặc tên thật của tác gỉa, như Nguyễn Xuân Hoàng (theo thứ tự tiếng Việt: họ, tên lót, tên). Một số tên cũng có danh xưng đi trước để chỉ một chức vị danh dự hay pháp danh nhà Phật. Hơn nữa, một số gia đình danh giá nhiều đời cũng được nhận biết không chỉ qua họ, mà cả tên lót. Vì sự đa dạng của bút danh trong tiếng Việt, và để giúp cho việc nhận diện các tác giả được đồng nhất trong cả hai bản Anh và Việt của bài viết, tôi chọn giữ nguyên tên theo thứ tự tiếng Việt của các tác giả xuất bản chủ yếu bằng tiếng Việt, hoặc chỉ bằng tiếng Việt. Quan trọng hơn cả, không nên thay đổi thứ tự của một bút danh (ngay cả khi nó hoàn toàn giống như tên thật), và không nên viết tắt bất cứ một phần nào của tên - nếu không, người đọc sẽ không biết tác giả đó là ai. Ví dụ, không ai sẽ liên tưởng "Vũ, Á." đến "Vũ Ánh" nếu chúng ta theo cách ghi APA. Tôi nhận thấy nhiều tài liệu Anh ngữ vẫn giữ thứ tự nguyên thuỷ của tên tác giả Việt Nam (như "Nguyễn Du" hoặc "Hồ Xuân Hương"). Trong những tác phẩm của mình trong tiếng Anh cũng như tiếng Việt, tôi cũng giữ cách viết tên tiếng Việt để thích hợp với văn hoá Việt và để giúp độc giả nhận diện đúng tác giả.

Một số thông tin về những tài liệu tiếng Việt được trích dẫn trong bài này còn thiếu, như thành phố, nơi mà tài liệu đó được xuất bản. Đó là do việc xuất bản trong cộng đồng thường không theo khuôn mẫu và không được ghi chép lại, nhất là những tác phẩm được in trong thập niên 1980 và 1990 . Tôi dành vài tuần lễ để tìm một số thông tin về các tác phẩm tiếng Việt, nhất là thành phố xuất bản, nhưng vô hiệu. Ngay cả một nhà xuất bản cũng 'lưu động' vì thường được tổ chức ở một tư gia của một thành viên trong nhóm văn hữu, và nếu vai trò chủ bút được giao chuyển cho người khác, thì nhà xuất bản cũng 'dọn đi.' Hơn nữa, nhiều tác giả hoặc người xuất bản đã qua đời, và danh sách của nơi họ cư ngụ trong lúc họ đóng vai trò người xuất bản không những không được giữ lại mà còn là thông tin cá nhân. Đôi khi cầm quyển sách trên tay mà cũng không tìm được nhiều mẩu thông tin cho việc trích dẫn là vì vậy.

\section{Tài liệu tham khảo}

Cao, Lan. (1997). Monkey Bridge. New York, NY: Viking Penguin. Cao, Lan. (2014). The Lotus and the Storm. New York, NY: Viking Press.

Danh, Bình. (2005). Immortality, The Remnants of the Vietnam and American War. Retrieved from http://binhdanh.com/Projects/Immortality/Immortality.html

*Du Tử Lê. (1987). “Cám ơn Pendleton” in Tho Tình. Tủ Sách Văn Học Nhân Chứng Publishing.

Đỗ, Khoa. (Producer), \& Manning, Jane (Director). (2001). Delivery Day [Short Film]. Australia: Porchlight Films.

Đỗ, Khoa. (Director). (2006). Footy Legend [Feature Film]. Australia: Megan McMurchy.

Đố, Khoa. (Director). (2010). Mother Fish [Feature Film]. Australia: Imaginefly.

*Đỗ Văn Phúc. (2008). Cuối Tầng Địa Ngục. Houston, TX: Vietland Publishing. 
Trangdai Glassey-Tranguyen- Biểu Đạt Căn Tính Di Dân trên Quê Huoong Việt-Mỹ và tại Hải Ngoại

Emmanuel, A. (2014, March 17). Rapper John 'Vietnam' Nguyen honored with street name in Uptown. Retrieved from http://www.dnainfo.com/chicago/20140317/uptown/rapperjohn-vietnam-nguyen-honored-with-street-name-uptown

Glassey-Tranguyen, Trangdai, \& Đỗ, Khoa. (2009, April 3). Biographical oral history interview/Interviewer: Trangdai Glassey-Tranguyen. Vietnamese Diasporas Project, Santa Ana, CA.

Glassey-Tranguyen, Trangdai, \& Trần, Hàm. (2011). Biographical oral history interview/Interviewer: Trangdai Glassey-Tranguyen. Vietnamese Diasporas Project, Anaheim, CA.

*Glassey-Tranguyen, Trangdai, \& Du Tử Lê. (2002, February 2). Biographical oral history interview/Interviewer: Trangdai Glassey-Tranguyen. Vietnamese American Project, Center for Oral \& Public History, CSU Fullerton, Garden Grove, CA.

Glassey-Tranguyen, Trangdai, \& Levan, Simon. (2000, January 9). Biographical oral history interview/Interviewer: Trangdai Glassey-Tranguyen. Vietnamese American Project, Center for Oral \& Public History, CSU Fullerton, Westminster, CA.

*Glassey-Tranguyen, Trangdai, \& Phạm Phú Minh. (1999, December 15). Biographical oral history interview/Interviewer: Trangdai Glassey-Tranguyen. Vietnamese American Project, Center for Oral \& Public History, CSU Fullerton, Westminster, CA.

Glassey-Tranguyen, Trangdai, \& Nguyễn, Paul. (2000, April 7). Biographical oral history interview/Interviewer: Trangdai Glassey-Tranguyen. Vietnamese American Project, Center for Oral \& Public History, CSU Fullerton, Westminster, CA.

Glassey-Tranguyen, Trangdai, \& Nghiêm, Đại Đạo. (2000, November 19). Biographical oral history interview/Interviewer: Trangdai Glassey-Tranguyen. Vietnamese American Project, Center for Oral \& Public History, CSU Fullerton, Pittsburgh, PA.

Glassey-Tranguyen, Trangdai, \& Phong, Ann. (2000, May 7). Biographical oral history interview/Interviewer: Trangdai Glassey-Tranguyen. Vietnamese American Project, Center for Oral \& Public History, CSU Fullerton, Cerritos, CA.

Glassey-Tranguyen, Trangdai, \& Đào, Thắng. (2011). Biographical oral history interview/Interviewer: Trangdai Glassey-Tranguyen. Vietnamese Diasporas Project, Columbia University/Manhattan, NY.

Glassey-Tranguyen, Trangdai, \& Vũ, Thiênnữ. (2000, August 12). Biographical oral history interview/Interviewer: Trangdai Glassey-Tranguyen. Vietnamese American Project, Center for Oral \& Public History, CSU Fullerton, San Francisco, CA.

Glassey-Tranguyen, Trangdai. (2008). (Women) Civilians after wars: Any nation state asking for their forgiveness?. in D. White \& S. Schulman (Eds.), Forgiveness: Probing the boundaries (pp. 223 - 229). United Kingdom: Inter-Disciplinary Press.

Glassey-Tranguyen, Trangdai. (2011a). Biển-đời: ann phong và nguyễn việt hùng trong những sáng tạo mới [Art critique of Tandem-Solo Exhibit of latest works by Ann Phong and Nguyễn Việt Hùng]. Westminster: Người Việt Daily Community Room.

Glassey-Tranguyen, Trangdai. (2011b). Tam Bảo của tôi: Ba tập thơ Thiền song ngữ của Nguyên Giác Phan Tấn Hải [Review of set of three bilingual Zen poetry books compiled and annotated by Phan Tấn Hải entitled Lời Dạy Tù Các Thiền Su Việt Nam Xưa - Teachings From Ancient Vietnamese Zen Masters; Trần Nhân Tông, Đức Vua Sáng Tổ Một Dòng Thiền - Trần Nhân Tông: The King Who Founded A Zen School; and The Wisdom Within - Teachings And Poetry Of The Vietnamese Zen Master Tuệ Trung Thương Sĩ]. Thư Viện 
Trangdai Glassey-Tranguyen- Biểu Đạt Căn Tính Di Dân trên Quê Huoong Việt-Mỹ và tại Hải Ngoại

Hoa Sen. Retrieved at http://thuvienhoasen.org/a12436/tam-bao-cua-toi-ba-tuyen-tapthien-thi-song-ngu-cua-cu-si-nguyen-giac.

Glassey-Tranguyen, Trangdai. (2011c). Mother Fish - Cá Mẹ: Tâm Thức Việt giữa dòng Thế Giới Hiện Đại [Review of the film Mother Fish, by K. Đỗ].

Glassey-Tranguyen, Trangdai. (2011d, August 6). Căn Nhà Ngói Đỏ: Nguyễn Xuân Hoàng giữa

Trập trùng Tiềm thức [The Red-roofed House: Nguyễn Xuân Hoàng amid the Waves of Subconsciousness] [Review of the book Căn Nhà Ngói Đỏ [The Red-Roofed House] by Nguyễn Xuân Hoàng]. Diễn Đàn Thế Kỷ Magazine. Retrieved at http://www.diendantheky.net/2011/08/can-nha-ngoi-o-nguyen-xuan-hoang-giua.html.

Glassey-Tranguyen, Trangdai. (2011e). Thụ Phấn: Một mảng Lịch sử Việt Nam trong Vũ điệu

Ballet [Review of ballet performance entitled Quiet Imprint - Vết Lăn Trầm by Thắng Đào].

Glassey-Tranguyen, Trangdai. (2012a). "Một năm xa Người-Nhạc-Sĩ Hát-Mãi-Vì-Yêu Nguyễn

Đức Quang." Sống Weekly.

Glassey-Tranguyen, Trangdai. (2012b). Đường Phía Bắc:’ Mảng lịch sử câm nín. [Book Review of Đường Phía Bắc by Lê Đại Lãng]. Houston: Trẻ Weekly.

Glassey-Tranguyen, Trangdai. (2012c). Đời sống tuần hoàn: Triển lãm tranh \& ảnh nghệ thuật. [Art exhibition review]. Santa Ana: VAALA.

Glassey-Tranguyen, Trangdai. (2012d). Hàm Trần: Màn Bạc và Đời Thường [Hàm Trần: Silver

Screen and Real Life][Special Feature]. Việt Báo Xuân - 2012 Annual Spring Anthology.

Glassey-Tranguyen, Trangdai. (2012e, February 14). Thắng Đào, Vũ Điệu Ballet, Lịch sử Da

Vàng[Thắng Đào, Ballet, and Yellow History]. Retrieved from http://www.dutule.com/D_1-2_2-94_4-4100/trangdai-glassey-tranguyen-thang-dao-vudieu-ballet-lich-su-da-vang.html

Glassey-Tranguyen, Trangdai. (2012f). "Trái tim nghệ thuật Thắng Đào" [The Heart of Thắng Đào’s Art][Special Feature]. Việt Báo Xuân - Annual Spring Anthology, 2012.

Glassey-Tranguyen, Trangdai. (2013a). Cũng Cần Có Nhau: Bản-lề Hoàng Xuân Sơn [In Need of Each Other: Hoàng Xuân Sơn The Hinge]. [Book Review of Cũng Cần Có Nhau by Hoàng Xuân Sơn]. Gió O. Retrieved at http://www.gioo.com/TrangDai/TrangDaiGlasseyTranguyenHoangXuanSon.htm.

Glassey-Tranguyen, Trangdai. (2013b). Tự Lực Văn Đoàn: Tám mươi năm sau càng rực rỡ. [Conference Review of "Hội Thảo và Triển Lãm Tự Lực Văn Đoàn”]. Người Việt Daily Community Room, Westminster, CA.

Glassey-Tranguyen, Trangdai. (2013c). "Việt Hồ Lê: Một Nghệ Sĩ toàn cầu đa năng, đa dạng - A Protean Global Artist.” Bilingual Interview in 2009 \& 2014. Sáng Tạo. Retrieved at http://sangtao.org/2013/04/15/viet-ho-le-mot-nghe-si-toan-cau-da-nang-da-dang/.

Glassey-Tranguyen, Trangdai. (2013d, July 17). Bilingual public address as a Fulbright Scholar, Media Representative, and Founder/Director of Vietnamese Diasporas Projects. Presentation given at CSU Fullerton's Vietnamese community education night to introduce three Vietnamese programs, Garden Grove, CA.

Glassey-Tranguyen, Trangdai. (2013e, October 12). Sụ Thật Âm Lòng về Phan Nhật Nam [The Heart-warming Truth about Phan Nhật Nam]. Keynote presented at Book Release of Phận Người, Vận Nước [A Person's Lot, A Country's Life (my translation)] by Phan Nhật Nam, Little Saigon, CA.

Glassey-Tranguyen, Trangdai. (2014a, December 6). 40 Năm Văn Học Miền Nam Thất Thủ: Thế hệ Hậu Chiến khước tù Thân phận Mồ côi [Forty Years After the Siege of South 
Trangdai Glassey-Tranguyen- Biểu Đạt Căn Tính Di Dân trên Quê Huoong Việt-Mỹ và tại Hải Ngoại

Vietnam's Literature: The Postwar Generations Refuse the Orphan Lot]. Presented at the conference Văn Học Miền Nam 1954-1975, Orange County, CA.

Glassey-Tranguyen, Trangdai. (2014b, July 19). Thung Lũng Tử Thần: Hít Thở Bóng Tối Hy Vọng Với Vũ Ánh [The Valley of Death: Breathing the Darkness of Hope with Vũ Ánh]. Keynote presented at posthumous book release and book review at Người Việt Daily News Community Room, Westminster, California.

Glassey-Tranguyen, Trangdai. (2014c). Chuyện kể bên bàn cơm: Tái thiết quá khư với Đạo diễn Khoa Đô̂/Interviewer: Trangdai Glassey-Tranguyen. Da Màu, Santa Ana.

Glassey-Tranguyen, Trangdai. (2014d). "Race/class/gender in the eye and life of director khoa đỗ: a perspective in film - sắc tộc/giai cấp/giới tính trong cái nhìn điện ảnh và cuộc đời của đạo diễn khoa đỗ." Bilingual Interview in Santa Ana, CA (Oral history interview in English, Vietnamese rendition by GTT). Online Magazine: Da Màu.

Glassey-Tranguyen, Trangdai. (2014e). "Ann-phong tại ann-home: ngọn gió nghệ thuật việt tại anaheim." [Art critique of Ann Phong's solo exhibition, Anaheim, CA]. Sáng Tạo. Retrieved at http://sangtao.org/2014/02/05/ann-phong-tai-ann-home-ngon-gio-nghethuat-viet-tai-anaheim/.

Glassey-Tranguyen, Trangdai. (2014f). "Ocean Vương: Tales of Disjunctured Homes - Câu Chuyện của Những Mái Ấm Đứt Đoạn.” Interview in English with Vietnamese version by TGT. Westminster, CA: Viễn Đông Daily News.

Glassey-Tranguyen, Trangdai. (2014g, February 18). A Fulbright Perspective on Advocacy for Vietnamese-English Dual Immersion Education. Public address presented at Garden Grove Unified School District Board Meeting, Garden Grove, California.

Glassey-Tranguyen, Trangdai. (2015). "Home in Stockholm: Vietnamese Diasporic Narratives of Transnationalism" in Quan Tran, Thu-Huong Nguyen-Vo, \& Mariam B. Lam (Eds.), Routes of Engagement: Việt Nam and Diasporas. Oxford, UK: Routledge.

*Hà Thúc Sinh. (1985). Đại Học Máu: Chuyện kể về 1685 ngày tù duới chế độ Cộng sản Việt Nam (The Blood University: Accounts of 1685 Days of Incarceration under Vietnamese Communist Regime). N/A: Nhân Văn Publishing.

*Hoàng Xuân Sơn. (2013). Cũng Cần Có Nhau [In Need of Each Other]. Canada: Nhân Ảnh Publishing.

Kim Thuy. (2012). Ru. Montreal, Canada: Random House Canada.

*Lê Đại Lãng. (2012). Đường Phía Bắc. Houston, TX: Trẻ Publishing.

lê thị diễm thuý. (2003). The Gangster We're All Looking For. Knopf, 2003);

*Nam Lộc. (1975). "Vĩnh Biệt Sài Gòn.” Music Score/Song in Vietnamese.

*Mai Thảo. (1955). Đêm giã tù Hà Nội. Sài Gòn, Vietnam: Người Việt Publishing.

Nguyen, J. V. [John Vietnam]. (2012, December 9). John Vietnam Memorial Mural $x$ Heaven.[video file]. Retrieved from http://www.youtube.com/watch?v=ngYhkh4n5pk

Nguyen, L. \& Tran, H. (Producer), \& Tran, H. (Director). (2007). Journey from the Fall [Motion Picture]. United States: ImaginAsian Pictures.

*Nguyên Giác Phan Tấn Hải. (2010a). Lời Dạy Tù Các Thiền Su Việt Nam Xưa - Teachings From Ancient Vietnamese Zen Masters. Escondido, CA: Thiền Tri Thức Publishing.

*Nguyên Giác Phan Tấn Hải. (2010b). The Wisdom Within - Teachings And Poetry Of The Vietnamese Zen Master Tuệ Trung Thuợng Sĩ. Escondido, CA: Thiền Tri Thức Publishing. 
Trangdai Glassey-Tranguyen- Biểu Đạt Căn Tính Di Dân trên Quê Huoong Việt-Mỹ và tại Hải Ngoại

*Nguyên Giác Phan Tấn Hải. (2010c). Trần Nhân Tông, Đức Vua Sáng Tổ Một Dòng ThiềnTrần Nhân Tông: The King Who Founded A Zen School. Escondido, CA: Thiền Tri Thức Publishing.

*Nguyễn Thanh Nga. (2007). Đoá Hồng Gai. Westminster, CA: Việt Tide Magazine Publishing. Nguyễn, Thuyết Phong. (1995). Searching for a Niche: Vietnamese Music at Home in America. Kent, OH: Viet Music Publications.

*Nguyễn Xuân Hoàng. (1989). Căn Nhà Ngói Đỏ. Westminster, CA: Văn Nghệ Publishing.

*Nguyễn Xuân Hoàng. (1992). Bụi và Rác. Westminster, CA: Thanh Văn Publishing.

*Nhã Ca. (2008). Giải Khăn Sô cho Huế. Westminster, CA: Việt Báo Daily News Publishing.

*Nhã Ca. \& Olga, D. (1968). The Mourning Headband for Huê: An account of the battle for Huế, Việt Nam 1968. Indiana: Indiana University Press.

*Phạm Xuân Đài. (1994). Hà Nội trong mắt tôi. Westminster, CA: Thế Kỷ Publishing. *Phan, Nhật Nam. (2013). Phận Nguơoi, Vận Nước. Westminster, CA: Sống Publishing.

Richardson, B. (2012, September 13). Gifted young hip-hop artist dies in apparent drowning. Poet was just about to start his sophomore year of college. WBEZ91.5. Retrieved from http://www.wbez.org/sections/art/gifted-young-hip-hop-artist-dies-apparent-drowning102416

Schmich, M. (2014, March 19). Hip-hop artist John Vietnam remembered on Argyle. Chicago Tribune. Retrieved from http://articles.chicagotribune.com/2014-03-19/news/ct-schmich0319-20140319_1_argyle-street-street-sign-little-vietnam

*Trầm Tử Thiêng. (1969). "Kinh Khổ.” Music Score/Song in Vietnamese.

*Trầm Tử Thiêng. (1991). "Bên Em Đang Có Ta.” Music Score/Song in Vietnamese.

*Trầm Tử Thiêng. (1996a). "Một Đời Áo Mẹ Áo Em." Music Score/Song in Vietnamese.

*Trầm Tử Thiêng. (1996b). "Một Ngày Việt Nam." Music Score/Song in Vietnamese.

*Trần Mộng Tú. (1990a). Tho Trần Mộng Tú. Westminster, CA: Người Việt Publishing.

*Trần Mộng Tú. (1990b). Câu Chuyện Của Lá Phong. Westminster, CA: Thế Kỷ Publishing.

*Trần Mộng Tú. (1996). Cô Rơm và Nhũng Truyện Ngắn. Westminster, CA: Văn Nghệ Publishing.

*Trần Mộng Tú. (1996). Để Em Làm Gió. Westminster, CA: Thế Kỷ Publishing.

*Trần Mộng Tú. (2009). Tho Tuyển Bốn Muơi Năm 1969-2009. (poetry chapbook). Seattle, WA: Self-published.

Tranguyen, Trangdai. (2004a). "Orange County, Yellow History: An Intimate Encounter with Vietnamese American Lives.” In T. J. Fusciano (Ed.), Journal of the Society of American Archivisits, 2(4), 5-28.

Tranguyen, Trangdai. (2004b). Faceless Wounds, Nameless Peace - Vết Thương Vô Diện, Hoà Bình Vô Danh. Bilingual book for the multi-genre cross-disciplinary bilingual program entitled concelebrating CSU Fullerton's Asian heritage month and Vietnamese Orange County's Black April Commemoration at Người Việt Daily News, Community Room, Westminster, CA. Fullerton, CA: Center for Oral \& Public History.

*Trịnh Công Sơn. (N/A). "Ngày Mai Em Đi.” Music Score/Song in Vietnamese.

Trương, Monique. (2003). Book Of Salt. First Mariner Books.

Trương, Monique. (2010). Bitter In The Mouth. Random House.

Võ, Danh. (2013). Mother Tongue [Mixed Media and Installation]. New York, NY: Metropolitan Museum of Art.

Võ, Danh. (2010-2014). We the People [International Installation Project]. New York, Chicago, and others: Public spaces, private galleries, and parks. 
Trangdai Glassey-Tranguyen- Biểu Đạt Căn Tính Di Dân trên Quê Huoong Việt-Mỹ và tại Hải Ngoại

Võ, Danh. (2013). Go Mo Ni Ma Da [Mixed Media and Installation]. Paris: Musée D'Art Moderne de La Ville de Paris.

*Vũ Ánh. (2014). Thung Lũng Tủ Thần. Westminster, CA: Người Việt Books.

Vũ, Howard. (2004). Chay Trong Cỏ Cao - Running in Tall Grasses (Bilingual Script and Short film) (Unpublished master's thesis in films). University of Southern California, Los Angeles, CA.

Vương, Ocean. (2010). Burnings. Poetry Chapbook. Sibling Rivalry Press.

Vương, Ocean. (2013). No. Poetry Chapbook. Yes Yes Books. 


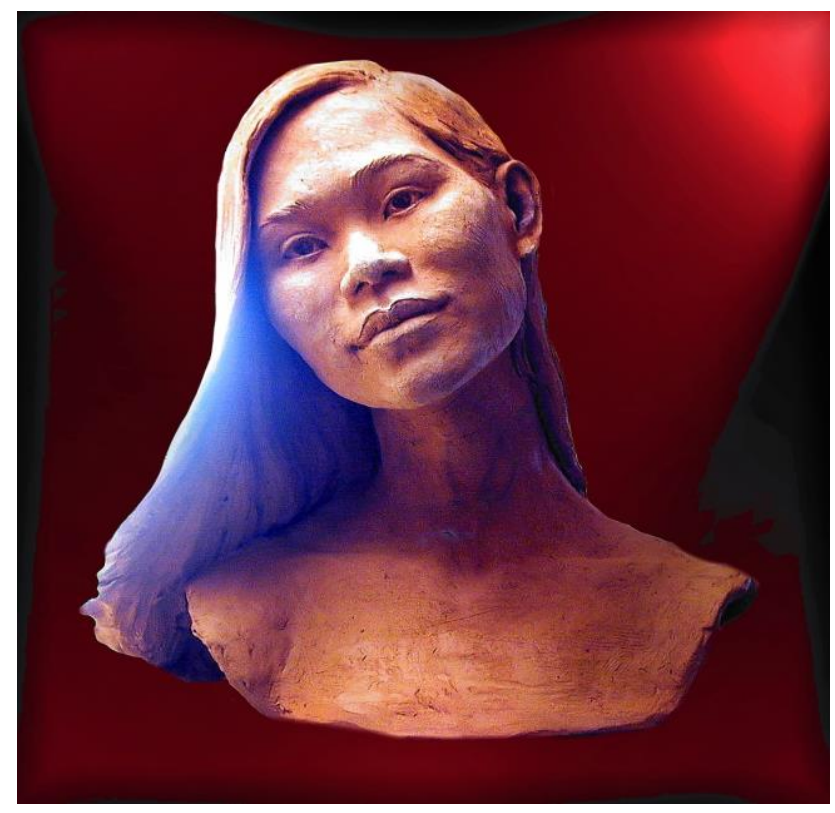

Một học giả đoạt nhiều giải thưởng và chuyên gia nghiên cứu đa ngữ về cộng đồng người Việt hải ngoại, Trangđài Glassey-Trầnguyễn là học giả duy nhất trên thế giới đã thực hiện hàng trăm cuộc phỏng vấn lịch sử truyền khẩu với người Việt ở cả bốn châu lục: Mỹ, Âu, Úc, và Á từ thập niên 1990. Trangđài được vinh danh rộng rãi vì những thành tích phục vụ cộng đồng, lãnh đạo thanh niên sinh viên, học thuật, sáng tạo, và nghiên cứu của cô.

Là học giả đầu tiên kết hợp nghiên cứu chiều sâu (ethnography) và lịch sử truyền khẩu (oral history) trong cộng đồng Little Saigon, Quận Cam, California, Trangđài nhận được nhiều giải thưởng cho các dự án nghiên cứu của mình. Cô đoạt giải quán quân tại cuộc tranh tài nghiên cứu của hệ thống CSU năm 2004 với bài viết "Quận Cam, Sử Vàng: Gặp Gỡ Thân Mật với Người Mỹ Gốc Việt” dựa trên dự án tiên phong ghi lại lịch sử của người Việt tại Quận Cam mang tên Vietnamese American Project, do cô sáng lập từ thập niên 1990 bằng chính student loans của mình. Là một học giả Fulbright toàn phần bậc tối ưu, cô thực hiện dự án nghiên cứu đầu tiên về người Việt tại Thuỵ Điển từ năm 2004 mang tên "Nhà ta ở Stockholm: Chứng từ Liên quốc gia của người Việt.” Từ năm 2004, Trangđài mở rộng môi trường nghiên cứu đến mười nước Châu Âu khác để có một cái nhìn toàn châu lục về di dân và những cộng đồng thiểu số tại đây. Cô bắt đầu dự án Việt Bá Linh năm 2005, với tựa đề "Ngồi Chồm Hổm ở Một Berlin Sắc Tộc: Căn Tính Việt Hải Ngoại trong Bối cảnh Phân chia Nhân đôi và Tột đỉnh.” Trangđài tốt nghiệp Cao học ngành Lịch sử tại Đại học CSU Fullerton với hai giải xuất sắc toàn trường, và Cao học ngành Nhân chủng học tại Đại học Stanford với luận án về các cô dâu Việt lấy chồng nước ngoài, và hiện đang hoàn tất chương trình tiến sĩ.

Là một tác giả song ngữ được nhiều người biết đến, Trangđài đã xuất bản hơn 1,000 tác phẩm thơ, sáng tạo, dịch thuật, bình luận, và chuyên đề trong các tạp chí nghiên cứu, sách giáo khoa trình độ Mẫu giáo đến lớp 12, các tuyển tập, những đặc san chuyên đề, và các báo chí trên thế giới. Cô là tác giả của năm tập thơ song ngữ, và có thơ được dịch qua mười ba ngôn ngữ khác từ năm 2001. Trangđài đã gỉang dạy, nghiên cứu, xuất bản, và thuyết trình bằng tiếng Việt và tiếng Anh về những đề tài và trong các chương trình liên quan đến tiếng Việt, văn hoá Việt, và cộng đồng Việt hải ngoại trong hơn 21 năm qua từ trình độ Mẫu giáo đến đại học. Trong bốn năm vừa qua, Trangđài giúp vận động cho các chương trình giáo dục song ngữ Anh-Việt trong dòng chính, và đã xuất bản hơn 50 sách tiếng Việt có phần kèm ghi âm đọc mẫu cho trình độ Mẫu Giáo và Lớp Một cũng như cố vấn cho các chương trình này. 


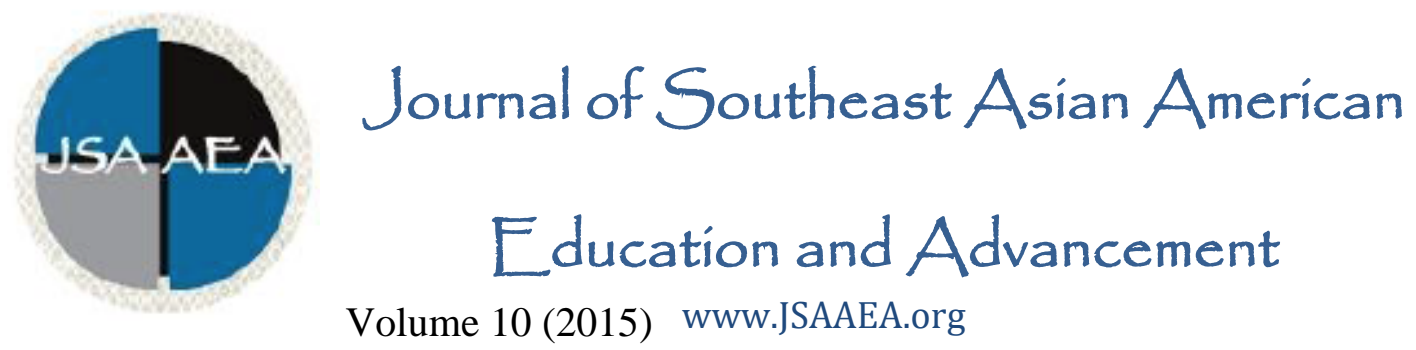

\author{
Editor \\ Dr. Wayne E. Wright \\ Purdue University \\ Associate Editors \\ Dr. Chhany Sak-Humphry \\ University of Hawaii at Manoa \\ Dr. Phitsamay Sychitkokhong Uy \\ University of Massachusetts, Lowell \\ Book Review Editor \\ Dr. Vichet Chhuon \\ University of Minnesota \\ Creative Works Editor \\ Bryan Thao Worra \\ Lao Assistance Center \\ Journal Manager \\ Marshall Klassen \\ Purdue University
}

Editorial Review Board

\author{
Dr. Steve Arounsack \\ California State University, Stanislaus \\ Dr. Sovicheth Boun \\ The State University of New York at \\ Fredonia \\ Dr. George Chigas \\ University of Massachusetts, Lowell \\ Dr. Hien Duc Do \\ San Jose State University \\ Dr. Sophal Ear \\ Occidental College \\ Dr. Jeremy Hein \\ University of Wisconsin, Eau Claire
}

\author{
Dr. Carl L. Bankston III \\ Tulane University \\ Dr. Phala Chea \\ Lowell Public Schools
}

Dr. Loan Dao

University of Massachusetts, Boston

Dr. Changming Duan

University of Missouri, Kansas City

Dr. Sothy Eng

Lehigh University

Dr. Vincent K. Her

University of Wisconsin, Eau Claire

Journal of Southeast Asian American Education \& Advancement, Vol. 10 (2015) 


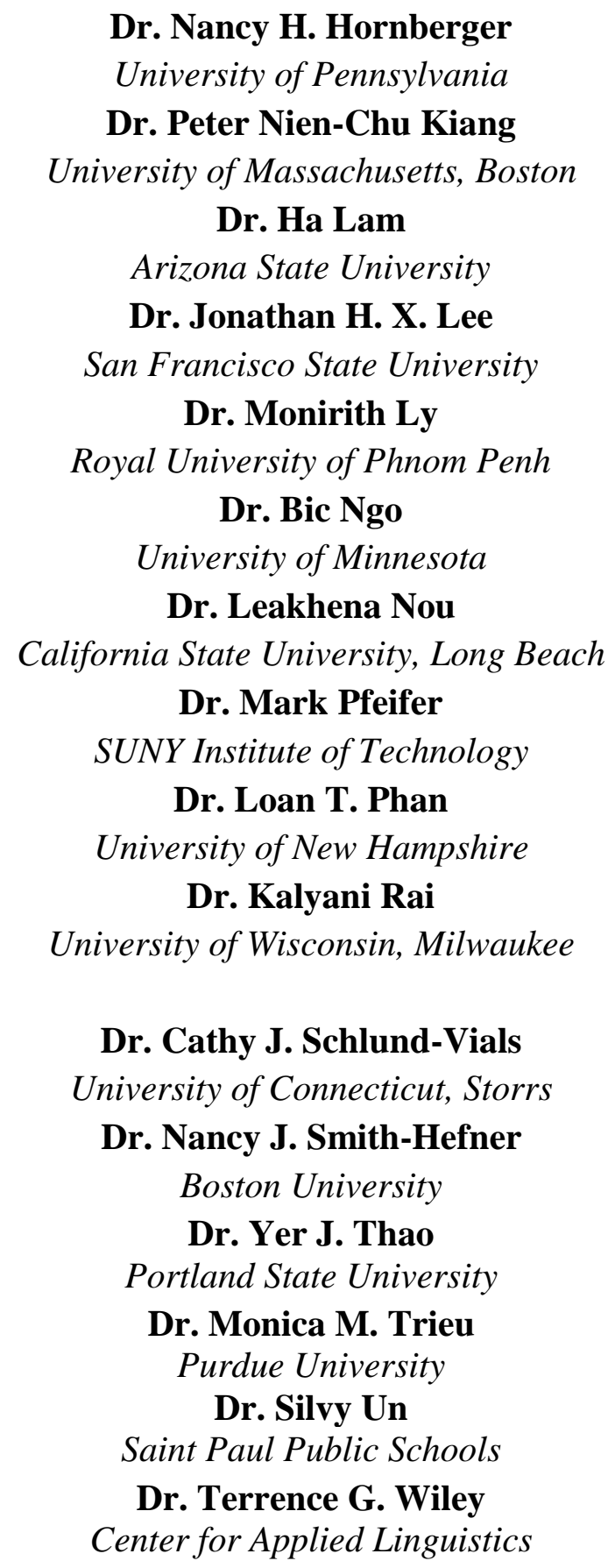

\author{
Dr. Peter Tan Keo \\ New York University \\ Dr. Kevin K. Kumashiro \\ University of San Francisco \\ Dr. Ravy Lao \\ California State University, Los Angeles \\ Dr. Stacey Lee \\ University of Wisconsin, Madison \\ Dr. Sue Needham \\ California State University, Dominguez Hills \\ Dr. Max Niedzwiecki \\ Daylight Consulting Group \\ Dr. Clara Park \\ California State University, Northridge \\ Dr. Giang Pham \\ University of Massachusetts \\ Dr. Karen Quintiliani \\ California State University, Long Beach \\ Dr. Angela Reyes \\ Hunter College, The City University of New \\ York \\ Dr. Fay Shin \\ California State University, Long Beach \\ Dr. Christine Su \\ Ohio University \\ Dr. Alisia Tran \\ Arizona State University \\ Dr. Khatharya Um \\ University of California, Berkeley \\ Dr. Linda Trinh Vo \\ University of California, Irvine \\ Dr. Yang Sao Xiong \\ University of Wisconsin-Madison
}

\section{Dr. Zha Blong Xiong}

University of Minnesota

\section{Doctoral Student Editorial Review Board}

\section{Virak Chan}

University of Texas at San Antonio

Annie BichLoan Duong

San Joaquin County Office of Education
Keo Chea-Young

University of Pennsylvania

Dung Minh Mao

University of Minnesota

Journal of Southeast Asian American Education \& Advancement, Vol. 10 (2015) 
Hoa Nha Nguyen

Boston College

Malaphone Phommasa

Marshall University

Molly Wiebie

The University of Texas at Austin
Thien-Huong Ninh

University of Southern California

Krissyvan Truong

Claremont Graduate University

Soua Xiong

San Diego State University \&

Claremont Graduate University

Anna H. Yang

University of Georgia

Journal of Southeast Asian American Education \& Advancement, Vol. 10 (2015) 